\title{
Ecosystem Feedbacks to Climate Change in California: Development, Testing, and Analysis Using a Coupled Regional Atmosphere and Land- Surface Model (WRF3-CLM3.5)
}

Z. M. Subin

Energy \& Resources Group, University of California, Berkeley, and

Earth Sciences Division, Lawrence Berkeley National Laboratory

E-mail: subin@post.harvard.edu

W. J. Riley

Earth Sciences Division, Lawrence Berkeley National Laboratory

E-mail: wjriley@lbl.gov

J. Jin

Watershed Sciences, Utah State University, Logan

E-mail: jiming.jin@usu.edu

D. S. Christianson

Energy \& Resources Group, University of California, Berkeley

E-mail: dsvehla@berkeley.edu

M. S. Torn

Earth Sciences Division, Lawrence Berkeley National Laboratory

E-mail: mstorn@lbl.gov

L. M. Kueppers

School of Natural Sciences and Sierra Nevada Research Institute, University of California, Merced

E-mail: lkueppers@ucmerced.edu 
Abstract

We coupled a regional atmosphere (WRF3) and land-surface (CLM3.5) model to study interactions between the atmosphere and possible future California land cover changes. We evaluated the impact on California's climate of changes in natural vegetation under climate change and of intentional afforestation. We assessed the ability of WRF3 to simulate California's climate by comparing simulations by WRF3-CLM3.5 and WRF3-Noah to observations from 1982-1991.

Using WRF3-CLM3.5, we performed six 13-year experiments using historical and future large-scale climate boundary conditions from the GFDL-CM2.1. The land cover scenarios included historical and future natural vegetation from the MC1 dynamic vegetation model, in addition to a future 8 million hectare California afforestation scenario.

Natural vegetation changes alone caused summer daily mean $2 \mathrm{~m}$ air temperature changes of -0.7 to $+1{ }^{\circ} \mathrm{C}$ in regions without persistent snow cover, depending on location and the type of vegetation change. Vegetation temperature changes were much larger than $2 \mathrm{~m}$ air temperature changes because of the fine-scale spatial heterogeneity of our imposed vegetation change. Up to $30 \%$ of the magnitude of the summer daily mean $2 \mathrm{~m}$ air temperature increase and $70 \%$ of the magnitude of the 4 PM vegetation temperature increase projected under future climate change was attributable to the climate driven shift in land cover. We projected that afforestation could cause local $0.2-1.2^{\circ} \mathrm{C}$ reductions in summer daily mean $2 \mathrm{~m}$ air temperature and $2.0-3.7^{\circ} \mathrm{C}$ reductions in 4 PM vegetation temperature for snow-free regions, due primarily to increased evapotranspiration. Because some of these temperature changes are of comparable magnitude to those projected under climate change this century, projections of climate and vegetation change in this region need to consider these climate-vegetation interactions. 


\section{Introduction}

Land cover and land use change can alter surface properties in ways that can significantly affect climate, especially at the regional scale and at the surface. The replacement of natural grasslands and forest cover with crops has likely caused cooling of $1-2.5^{\circ} \mathrm{C}$ in the central and eastern United States (Bonan 1999; Bonan 1997; Diffenbaugh 2009) and $\sim{ }^{\circ} \mathrm{C}$ in temperate latitudes overall (Bounoua et al. 2002). Global historical land cover change may have weakened Northern hemisphere Hadley circulation while causing regional temperature changes of up to 5 ${ }^{\circ} \mathrm{C}$ (Feddema et al. 2005a), while future expansion of agricultural land may continue to warm the tropics while cooling mid-latitudes (Feddema et al. 2005b); conversely, intentional afforestation in low latitudes could cause local cooling (Narisma and Pitman 2006). Changes in land management, such as the introduction of irrigation, can greatly contribute to temperature changes associated with a shift of land cover to agriculture (Kueppers et al. 2007; Kueppers et al. 2008; Lobell et al. 2008a; Lobell et al. 2008b; Sacks et al. 2009; Weare and Du 2008). Temperature changes are often largest during summer because high surface net radiation magnifies the effect of land surface properties on surface energy fluxes (Bonan 1997; Diffenbaugh 2009; Kueppers et al. 2007). If a land cover change occurs over a large enough region, changes in cloudiness and regional circulation may occur that cause subsequent changes in regional climate (Abiodun et al. 2008; Roy and Avissar 2002; Zhao et al. 2001), including altered regional precipitation (Diffenbaugh 2009; Ge et al. 2007; Pielke et al. 2007). Temperature changes resulting from historical or predicted land cover change are as large in some regions as that expected from $21^{\text {st }}$ century global climate change, so proper attribution and prediction of climate change needs to consider land cover change (Diffenbaugh 2009; Feddema et al. 2005b).

Most global studies have demonstrated that the largest climatic impacts of land cover and land use change occur within the modified region (Bounoua et al. 2002; DeFries et al. 2002; Feddema et al. 2005a). Consequently, regional climate models are important tools for investigating the impacts of land cover and land use change. While they lack the capability to show feedbacks from within the region to large-scale atmospheric circulation, they can resolve land cover and land use changes and their interaction with topography with much finer detail than general circulation models. 
Many existing regional climate models use relatively simple land surface schemes. However, there have been recent efforts to integrate more comprehensive land surface models into regional climate models. For example, a coupling of CLM and RegCM improved simulation of soil moisture and winter temperature over East Asia (Steiner et al. 2005), and was used to simulate interactions between land cover and the west African monsoon (Steiner et al. 2009). The coupling of RegCM and IBIS improved simulation of latent heat flux over the U.S. compared to FLUXNET observations, although it decreased performance for other surface variables (Winter et al. 2009). A coupling between LSM and MM5 predicted that early harvesting of Midwest crops raised surface air and soil temperature by $1-2{ }^{\circ} \mathrm{C}$ (Cooley et al. 2005). Finally, SiB and RAMS were coupled to investigate ecosystem $\mathrm{CO}_{2}$ fluxes in Wisconsin (Denning et al. 2003).

Ecosystems and climate form a feedback cycle since changes in climate can affect the distribution and properties of land cover, and land-cover change can alter regional climate (Foley et al. 2003). Climate-ecosystem feedbacks have been shown to be of sufficient magnitude that they need to be included to make accurate climate predictions (Friedlingstein et al. 2006; Lobell et al. 2008a; Torn and Harte 2006). Feedbacks between the land surface and atmosphere can be grouped into two categories: biogeophysical (our focus here) and biogeochemical. Biogeophysical feedbacks result from energy, momentum, and moisture exchanges with the atmosphere, and are affected by soil and canopy radiative properties, surface roughness, leaf area index, stomatal resistance, and rooting depth (McPherson 2007). Because the response of ecosystems to climate change is often regionally specific, and because biogeophysical feedbacks typically have their largest climatic effects regionally (Bala et al. 2007), an understanding of regional-scale feedbacks is critical for accurate predictions of regional climate change.

Reliable predictions of regional climate are important input to policies for mitigating and adapting to climate change. However, land cover and topography in California are spatially heterogeneous at a much finer scale than that resolved by state-of-the-art global climate models. Dynamical downscaling is one method for translating global climate model predictions into realistic changes in spatially heterogeneous regions. Several dynamical downscaling studies have examined the impacts of anthropogenic climate change on California, and have predicted aboveaverage temperature increases at higher elevations (Bell and Sloan 2006), a shift during winter to more rain and less snow (Leung et al. 2004), earlier spring snowmelt (Hayhoe et al. 2004; Leung 
et al. 2004; Snyder and Sloan 2005; Snyder et al. 2002), more severe heat waves (Bell and Sloan 2006; Hayhoe et al. 2004), and increases in winds that drive coastal water upwelling (Snyder et al. 2003). However, these studies did not include potential changes in ecosystem properties resulting from climate change, nor the climate feedbacks that may result from such changes.

Dynamic vegetation models have been used to predict shifts in vegetation distribution and properties, ecosystem productivity, and fire frequency across the globe (Alo and Wang 2008; Bonan et al. 2003; Notaro et al. 2007; Sitch et al. 2003; Thonicke et al. 2001), including in California. In this study we use output from the MC1 model, which predicts future vegetation cover in California (Lenihan et al. 2003; Lenihan et al. 2008). MC1 predicted net increases in fractional cover of desert, grassland, and mixed evergreen forest at the expense of conifer forest and alpine/subalpine forest during the $21^{\text {st }}$ century. However, the California MC1 studies did not quantify the effects of these ecosystem changes on climate.

One previous study (Diffenbaugh 2005) quantified two-way climate-ecosystem feedbacks in the western United States by using an equilibrium vegetation model to estimate changes in ecosystem distribution and then using these distributions within a regional climate model to predict first-order effects on regional climate. Diffenbaugh (2005) found that up to 60\% of the seasonally averaged surface temperature change resulting from $\mathrm{CO}_{2}$-driven climate change was due to feedbacks from the land surface. Diffenbaugh (2005) used BATS (Yang and Dickinson 1996) within RegCM 2.5 (Giorgi and Shields 1999; Snyder et al. 2002) to translate changes in ecosystem distribution into changes in land-surface climate forcing, with a relatively simple treatment of California’s ecosystem types.

Here, we extend the work of Lenihan et al. (2008) and Diffenbaugh (2005) by developing a first-order estimate of the climate-ecosystem feedbacks in California using the MC1-predicted vegetation shifts, adapted into new California-specific plant functional types (PFTs) within CLM3.5. We used a fine resolution (20 km) regional climate model (WRF3-CLM3.5, described below) to evaluate the impact of vegetation change on the California regional climate. The use of several vegetation scenarios with both historical and future climate boundary conditions allowed us to separate the biogeophysical effects of local vegetation from the effects of large-scale climate change. 
Intentional afforestation for mitigating greenhouse gas emissions via carbon sequestration is another form of land cover change that could affect regional climate, and is being considered by policy-makers in many regions, including California. The biophysical effects of additional forest cover on climate are variable and uncertain. Recent reviews (Bonan 2008; Jackson et al. 2008) agree that adding forest to areas currently dominated by non-tree vegetation cover will cause regional warming for boreal zones and cooling for tropical zones, but studies have found contrasting results regarding the net regional temperature effect of increased forest cover in temperate latitudes. This difference is because adding trees causes two primary contrasting effects: decreases in surface shortwave albedo, which tends to increase surface air temperature, and increases in evapotranspiration, which tends to reduce surface air temperature. Temperature changes are dominated by the albedo decreases in boreal zones and the evapotranspiration increases in the tropics, while the two effects are often comparable in temperate zones. Additional effects in all three climate zones may include changes in cloudiness (Bala et al. 2007; Betts et al. 2007; Durieux et al. 2003; Xu et al. 2007) and regional circulation (Abiodun et al. 2008; Diffenbaugh 2009; Roy et al. 2003; Snyder et al. 2004b), with varying effects on local air surface temperature. One effect that may be important but has only been analyzed for boreal forests is the longwave forcing caused by increasing atmospheric water vapor when evapotranspiration increases over a large region (Swann et al. 2010).

For temperate zones, several climate model studies have found that the albedo effect predominates and causes surface warming, especially when forest is replacing cropland (Bala et al. 2007; Betts et al. 2007; Bounoua et al. 2002; Gibbard et al. 2005; Snyder et al. 2004a). Other modeling studies and one observational study have found that decreased Bowen ratios and increased cloudiness dominate, causing a net cooling (Jackson et al. 2005; Juang et al. 2007; Ramankutty et al. 2006; Roy et al. 2003; Strack et al. 2008). Many studies find seasonal and regional contrasts, with the albedo decrease being most significant in the winter over snow, and the evapotranspiration effect being more important in the summer during the daytime (Diffenbaugh 2005; Lamptey et al. 2005; Roy et al. 2003). The amount and duration of snow cover, which have a strong influence on the magnitude and timing of the albedo effect, vary widely in temperate areas. Because of the uncertain regional climate impacts of adding forest cover in temperature latitudes, we included in our simulations an afforestation scenario based on 
Brown et al. (2004), who estimated the potential in California for planting forests on rangeland deemed environmentally and economically suitable for carbon sequestration.

\section{Model Description and Experimental Design}

\subsection{Model Background and Architecture}

The Weather Research and Forecasting Model (WRF) is a widely used regional climate model that includes atmospheric dynamics and parameterizations of mesoscale atmospheric processes that are comparable to or more comprehensive than those found in most global climate models (Skamarock et al. 2008). WRF consists of a non-hydrostatic computational fluid dynamics core plus several physics modules to represent unresolved atmospheric processes (Skamarock and Klemp 2008). WRF has been tested by both the meteorological and climate communities, including over the central U.S. and California (Caldwell et al. 2009; Gallus and Bresch 2006; Michelson and Bao 2008).

However, the land surface model schemes available in WRF3.0 are much less comprehensive than those found in some global climate models, like the Community Land Model (CLM) (Bonan et al. 2002b), the land surface component of the Community Climate System Model (CCSM) (Collins et al. 2006). In this study, we coupled a recent version of CLM (CLM3.5) to WRF3.0 to take advantage of CLM's potential improvements over previous generation land surface models like Noah (Chen and Dudhia 2001; Skamarock et al. 2008), LSM (Bonan 1998), and BATS (Yang and Dickinson 1996).

CLM3.5 represents the surface by five primary sub-grid land cover types (glacier, lake, wetland, urban, \& vegetated) in each grid cell. The vegetated portion of a grid cell is further divided into patches of up to 4 of 16 plant functional types (PFTs) (Bonan et al. 2002a), each characterized by distinct physiological parameters (Oleson et al. 2004). Once calculations are performed at the PFT level, energy, water, and momentum fluxes are aggregated to the grid cell level and passed to the atmospheric model.

The extensive mechanistic detail and evaluation history of CLM (Bonan et al. 2002b; Dickinson et al. 2006; Oleson et al. 2003; Qian et al. 2006) are advantageous for modeling the climate impacts of land cover change. CLM includes a 5-layer snow scheme, a 10-layer soil 
scheme, and a single-layer vegetation scheme with a sunlit and shaded canopy (Dai et al. 2004; Oleson et al. 2004). The two-stream approximation (Sellers 1985) is applied to calculate solar radiation reflected and absorbed by the canopy as well as its transfer within the canopy. Temperature and humidity are allowed to be different at the ground surface, in the canopy, and at the leaf surface. Stomatal conductance is based on a mechanistic prediction of photosynthesis and its relationship to environmental conditions. CLM partitions evapotranspiration into transpiration, soil evaporation, and canopy evaporation (Lawrence et al. 2007). Solid ice, liquid water, and temperature are prognostic variables for each snow layer, and the snow density and albedo are adjusted as the snow undergoes aging and compaction. The snow albedo calculation over vegetation cover also includes a calculation of fractional snow cover based on the snow height.

CLM3.5 improves representations of hydrology, evapotranspiration (ET), and snow albedo compared to the previous version, CLM3.0 (Oleson et al. 2008). For instance, CLM3.5 allows for a flexible treatment of soil water availability, with PFT-dependent values of soil moisture potential at which stomatal opening and closing occurs, and a nonzero range in potential between soil water saturation and the onset of water stress. These features lead to increased simulated ET, reducing the low ET bias found in CLM3.0. In addition, CLM3.5 corrected a snow aging parameterization deficiency in CLM3.0, partially ameliorating the delayed snowmelt in CLM3.0 relative to observations.

CLM3.5 has a more comprehensive representation of land surface properties and processes than the Noah Land Surface Model (Chen and Dudhia 2001; Skamarock et al. 2008), which is the default option in WRF. While increasing complexity does not always lead to improved model performance, "second generation" and "third generation" land surface models (like CLM) have been shown to improve performance relative to "first generation" models (Henderson-Sellers et al. 2003; Pitman 2003); the Noah model has characteristics intermediate between "first generation" and "second generation" models as defined by Pitman (2003).

The coupling of WRF3 and CLM3.5 builds on a previous software coupling (Miller et al. 2009) between WRF2 and CLM3. The top level WRF driver structure is retained, and CLM is called as a subroutine within WRF. In the form used here, the PFTs are assigned to gridcells 
according to a fixed mapping from WRF’s 24 U.S. Geological Survey (USGS) land use categories to groups of up to 4 of CLM's 17 PFTs, including bare ground. The mapping is based on that used in LSM1 (Bonan 1998). Monthly LAI is prescribed for each PFT, and does not vary geographically. This approach makes the WRF3-CLM3.5 model easily accessible to the WRF community, while sacrificing some of the more detailed surface data normally prescribed in CLM.

\subsection{Control Simulations and Model Evaluation}

We evaluated WRF3-CLM3.5 with a 10-year simulation of the California region. WRF3 has not been evaluated extensively for long climate simulations, so we also evaluated WRF3 using the default Noah land surface model (Chen and Dudhia 2001; Skamarock et al. 2008) in a run that was otherwise identically configured to the WRF3-CLM3.5 run. This allowed us to test the default performance of WRF3 and insure that the CLM3.5 coupling did not degrade the performance of WRF3; furthermore, we could infer that biases with similar magnitudes and spatial patterns occurring in both WRF runs were likely due to the large-scale boundary conditions or WRF physics or dynamics, rather than the land surface model.

The model simulations included a parent domain centered at $35.979^{\circ} \mathrm{N}$ and $121.479^{\circ} \mathrm{W}$, with a $1 / 2^{\circ}$ equal latitude-longitude projection containing 75 east-west and 65 north-south points in its unstaggered grid. The domain used for evaluation was a nest with $16^{\circ}$ spacing, centered at $37.479^{\circ} \mathrm{N}$ and $120.479^{\circ} \mathrm{W}$, containing 93 east-west and 81 north-south points in its unstaggered grid (Figure 1). Twenty-five vertical layers were used, with higher resolution near the surface. We ran the model from January 1981- December 1991. We discarded the first year for spin-up; no time trends were visible after the first year in the model biases compared to observations, indicating that one year was sufficient spin-up for evaluation purposes. NCEP-DOE Reanalysis Project 2 data (Kanamitsu et al. 2002) was used for initial and boundary conditions. The physics options were the Lin microphysics scheme (Chen and Sun 2002), the RRTM longwave scheme (Mlawer et al. 1997), the Goddard shortwave scheme (Chou and Suarez 1994), the MoninObukhov surface layer scheme (Skamarock et al. 2008), the YSU PBL scheme (Hong et al. 2006), and the Kain-Fritsch cumulus scheme (Kain 2004; Skamarock et al. 2008). 
We compared both the WRF3-CLM3.5 and WRF3-Noah runs to interpolated observations from the Parameter-elevation Relationships on Independent Slopes Model (PRISM) (Daly et al. 2008) (http://www.prismclimate.org). PRISM is the official spatial climate data set of the U.S. Department of Agriculture, and it uses quality-controlled data from 10,000 U.S. local meteorological stations for temperature and 13,000 stations for precipitation. Using a digital elevation model, PRISM calculates a climate-elevation regression that considers coastal proximity, topographic facet orientation, vertical atmospheric layer, topographic position, orography, atmospheric inversions, coastal effects, and cold air drainage. PRISM has been used extensively in previous studies characterizing features of western U.S. climate, including the climate variability of California (Abatzoglou et al. 2009), the occurrence of drought in the southwest U.S. (Weiss et al. 2009), and climatic features of the drylands of western North America (Hughes and Diaz 2008).

We evaluated the performance of the two models using PRISM daily maximum and minimum $2 \mathrm{~m}$ air temperature $\left(\mathrm{T}_{2}\right)$, mean dewpoint temperature, and precipitation, averaged for each month over the same time period. The predicted maximum and minimum temperatures were found by extracting the maximum and minimum value from every 8 time points of the 3 hourly output. A separate 1-year run with 30-minute output indicated that this method was not likely to bias the mean simulated minimum and maximum temperatures by more than $0.2^{\circ} \mathrm{C}$. PRISM variables were averaged from $1 / 24^{\circ}$ resolution to the $1 / 6^{\circ}$ resolution of the model nest using an average over the PRISM points whose centers were contained in each nest gridcell, weighted by the area of the PRISM cell contained in the model cell. Overall biases, correlations, and variances were calculated for land points both over the whole domain and within California, as compared to the PRISM data, with each gridcell being considered a separate observation for each month in the 10-year period.

\subsection{Land Cover Change Experiments}

\subsubsection{Vegetation Datasets, Parameterizations, and Distributions}

We used six simulations to quantify the climate effects of changes in ecosystem distribution under historical and future climate (Table 1). The experiments investigated combinations of four different vegetation distributions: Historic Native Vegetation (HV), Future Native Vegetation 
(FV), Future Native Vegetation + Afforestation (FAV), and Historic Native + Afforestation (HAV). Using these vegetation scenarios with historical and future climate boundary conditions allowed for the separation of the effects of climate change alone, the effects of native vegetation change on climate alone, and the effects of afforestation alone.

The Historic Native and Future Native vegetation cases were derived from previously published MC1 simulations of natural vegetation (Lenihan et al. 2008). These vegetation distributions had been generated using monthly observed climate variables for the period 18952004, and monthly climate simulated by a GCM for 2005-2099. Our Historic Native vegetation distribution was obtained from the dominant 1961-1990 values for each grid cell, and our Future Native vegetation distribution was obtained from the dominant 2070-2099 values for each grid cell. We selected the MC1 output to match, to the degree possible, the boundary conditions available for driving RCM simulations (6 hourly GCM output required), but were constrained by what output had been archived and was available for distribution. For example, the Future Native distribution was based on climate output from the GFDL2.1 A2 scenario, as described below, but was only available for 2070-2099 while the required GCM output ended in 2070. While this results in a slight mismatch between the future climate and the future vegetation, we expect the discrepancy to be small compared to the differences between the historic and future periods. In California, MC1 predicted increases in the area covered by desert, grassland, and mixed evergreen forest at the expense of conifer forest and alpine/subalpine forest under the A2 scenario (Figure 2e; also see Figure 3 in Lenihan et al. 2008). MC1 does not represent urban or agricultural land, only potential natural vegetation, in what are today urban and agricultural areas.

We used the Küchler U.S. potential vegetation classification (Küchler 1975) to translate the MC1 vegetation distributions into combinations of PFTs specific to California (Table 4). Our goal was to differentiate California plant types by physiology, physiognomy, life history, and phenology. The Küchler classification uses historical climate, expert opinion, and observations to estimate spatially explicit potential vegetation cover (e.g., mixed conifer forest) as combinations of dominant and “other component” species. We matched each of these dominant and "other component” species to create 16 new CLM3.5 PFTs for California. 
We combined these 16 California-specific PFTs into vegetation cover types. The fractional cover of bare ground (BG), dominant species, and "other component” species (these three fractions sum to one) was assigned for each cover type. For forest and woodland covers, we imposed BG fractions based on Küchler’s descriptions of stand density, i.e., “dense” implied 15\%, “dense to open” implied 25\%, and “open” implied 40\%. For forest and woodland covers where there was no indication of BG fraction and for grassland, shrubland, and crop types, we used the California Native Plant Society / California Department of Fish and Game Vegetation Mapping protocols (T. Keeler-Wolf et al. Pers. Comm.) and expert opinion. The resulting bare ground fraction was similar to that used in LSM 1 (Bonan 1998) for analogous ecosystem types. We applied Küchler's descriptions, the Vegetation Mapping protocols, and expert opinion to quantify dominant and "other component" species fractions, since this information was not available in the Küchler vegetation covers. The species fractions were then converted to PFT fractions, resulting in PFT fractions for each Küchler cover. Finally, the PFT fractions associated with each Küchler cover were aggregated into the MC1 vegetation classes according to the scheme used by Lenihan et al. (2008), weighting the PFT fractions by their area within each MC1 vegetation class (Table 5).

PFT parameter values for the 16 new California PFTs were derived from published literature, remotely sensed datasets, or similar pre-existing CLM3.5 PFTs (Table 6). Efforts were made to use values for the dominant species associated with each PFT, weighted if possible by the fraction of the PFT that the species comprises (Table 6). Monthly leaf area index (LAI) for each California PFT was determined using MODIS 16-day LAI values (August 2004 - July 2005) masked using the California Gap Analysis vegetation cover type database (Davis et al. 1998), which had been interpolated to a $1 \mathrm{~km}$ resolution. For example, to determine the monthly LAI sequence for fire-dependent evergreen conifer, MODIS pixels overlapping the Gap Analysis pixels identified as Coast Range Ponderosa Pine Forest, Westside Ponderosa Pine Forest, Eastside Ponderosa Pine Forest, and Big Tree Forest were averaged. The resulting annual cycles of spatially explicit LAI values were compared with the unmasked MODIS values to ensure that they were reasonable (Table 7).

To represent potential changes in vegetation distribution as a consequence of deliberate afforestation to mitigate carbon dioxide emissions, we applied an analysis (Brown et al. 2004) 
that delineated areas meeting criteria for afforestation in California. This afforestation scenario identified areas with less than $40 \%$ canopy cover that would be suitable for enhanced tree cover according to historical climate, soil, and other biophysical factors. The scenario further limited afforestation areas to those where the costs (including opportunity costs) of converting the rangeland to forest were economically advantageous on an 80-year time horizon, under a range of carbon prices (Figure 2-28 in Brown et al. 2004). Areas deemed suitable excluded current agricultural, urban and wetland areas. According to this analysis, after 80 years, approximately 1.5 billion tonnes of carbon could be sequestered on 8.5 million hectares of land for $\$ 80$ or less per tonne of carbon. This area was near the high end of what Brown et al. (2004) considered the afforestation potential, and we used it to define our afforestation scenario (see below).

\subsubsection{Regional Climate Boundary Conditions}

The coupled WRF3-CLM3.5 simulations were forced with lateral atmospheric boundary conditions and sea surface temperatures every 6 hours using simulations from the Geophysical Fluid Dynamics Laboratory (GFDL) GCM version 2.1 (Delworth et al. 2006). Two different climate scenarios were used: $20^{\text {th }}$ century (Historical Climate, HC) and A2 Future (Future Climate, FC). The inputs to WRF were generated using a version of the WRF Preprocessing System modified to accept netcdf files. For the historical climate cases, we used atmospheric and oceanic model output from the GFDL2.1 20C3M (run 2) case (http://nomads.gfdl.noaa.gov/CM2.X/CM2.1/available_data.html). This GCM was chosen for the present study because output from this model had been used to drive the vegetation model that provided our vegetation scenarios, thereby ensuring that the climate forcing for our WRF3CLM3.5 simulations and for the future vegetation predictions were consistent. The GFDL2.1 also produced realistic seasonal cycles of temperature and precipitation in California, and interannual variability in climate reflecting that of historical observations (e.g., El Niño and La Niña features) (Cayan et al. 2008).

For the future climate cases, we used output from the same model's Special Report on Emissions Scenarios (SRES) A2 (Nakicenovic and Swart 2000) (run 1) case. In California, the GFDL GCM produces larger temperature increases under future greenhouse gas concentrations does than the Parallel Climate Model (Washington et al. 2000), but smaller increases than does 
the Hadley Center Climate Model 3 (Johns et al. 2003). The GFDL A2 scenario predictions at the end of the $21^{\text {st }}$ century (as compared to 2000) included: (1) a 10-20\% reduction in precipitation in Northern California, (2) increased frequency of large precipitation events in Northern California (including a tripling in the frequency of 99.9 percentile events), and (3) little change in frequency of El Nino events (Cayan et al. 2008).

\subsubsection{Model Configuration and Analysis}

We conducted four primary experiments to separate the effects of climate change alone (FCHV compared to HCHV), the effects of vegetation change on climate alone (FCFV compared to FCHV), and the effects of future afforestation alone (FCFAV compared to FCFV) (Table 1). Two additional comparisons (HCFV compared to HCHV and HCHAV compared to HCHV) were included as sensitivity cases in order to assess any secondary interactions between climate and vegetation change, such as whether the impact of vegetation change on $2 \mathrm{~m}$ air temperature is dependent on the mean climate. Thirteen-year simulations were performed for each of the cases (1968-1980 for the $20^{\text {th }}$ c. runs and 2058-2070 for the future climate runs). The physics options used were the same as those used in the evaluation runs described above.

We configured WRF3-CLM3.5 with a $20 \mathrm{~km}$ horizontal grid and 25 vertical layers in a Lambert-conformal projection. The domain was centered on $37.0^{\circ} \mathrm{N}$ and $120.0^{\circ} \mathrm{W}$ and comprised 74 grid cells in the east-west direction and 79 in the north-south direction for the unstaggered grid. Outside of California, the 24 USGS land cover types specified land cover, which were then mapped to combinations of 4 standard CLM PFTs including bare ground, as done over the whole model evaluation domains. Within California, one of the 14 MC1 vegetation categories (each containing up to 4 California PFTs, as described above) was assigned to each model grid cell by choosing the dominant MC1 vegetation category.

For the afforestation scenarios, either the Future Native vegetation (for the FCFAV case) or the Historical Native vegetation (for the HCHAV sensitivity case) was used as a base, and then the afforestation mask (Brown et al. 2004) was interpolated onto the model domain. Areas under the mask falling into the categories of grassland, shrubland, or tundra were replaced by continental temperate coniferous forest vegetation (see Table 5). The four vegetation maps used for California are shown in Figure 2. 
None of the experiments represented urban or agricultural land cover or changes in these cover types. Other factors that influence regional climate, including aerosols and agricultural irrigation (Lobell et al. 2008a), were not included in the present study. Atmospheric $\mathrm{CO}_{2}$ concentrations were held constant at $380 \mathrm{ppm}$ in the regional model domain for all cases to isolate climate effects from $\mathrm{CO}_{2}$ effects.

We analyzed averages of primary surface climate and energy budget variables for the latter 10 years of each simulation, leaving the first three years for spin-up. Seasonal and annual means of daily mean, daily 4 PM, and daily 4 AM values were calculated for each variable of interest at each gridcell. The statistical significance of results was evaluated with a paired t-test at the gridcell level. Except for albedo and precipitation changes, all figures presenting differences between experimental runs show only gridcells with significant changes at the $95 \%$ confidence level. We highlighted several regions experiencing both significant temperature changes and coherent vegetation changes across at least $\sim 100 \mathrm{~km}^{2}$, but lacking problematic high precipitation and snow accumulation biases (see below) (Transitions A-D, respectively; Figure 2).

\section{Results \& Discussion}

\subsection{Model Evaluation (Historical Climate)}

The model results for 1982-1991 show that both WRF3-CLM3.5 and WRF3-Noah reasonably simulated the patterns of temperature variation over the California region (Figure 3ad), suggesting that both models were capturing the effects of topography and vegetation on the near-surface atmosphere, although substantial regional biases remained. (See Table 2 for overall statistics from the model evaluation results.) Both WRF3-CLM3.5 and WRF3-Noah simulated daily maximum temperature well, with less than $1{ }^{\circ} \mathrm{C}$ annual average biases and correlations of 0.97 (Figure 3c-d) for monthly-averaged daily maximum temperature for all gridcells across the domain. However, both models over-predicted daily minimum temperature (Figure 3f-g) compared to PRISM data (Figure 3e), especially in the winter and over the inland (Nevada) portion of the domain: the annual average California biases are $2.9^{\circ} \mathrm{C}$ for CLM and $4.1{ }^{\circ} \mathrm{C}$ for Noah, with maximum local biases in minimum temperature up to $10^{\circ} \mathrm{C}$ for CLM and $11^{\circ} \mathrm{C}$ for Noah. 
Compared to annual average PRISM data (Figure 4a), WRF3-CLM3.5 replicated the dewpoint with little net bias (Figure $4 \mathrm{~b}$ ): $0.2{ }^{\circ} \mathrm{C}$ across the entire domain and $-0.9^{\circ} \mathrm{C}$ for California; the Southeastern part of the domain was too dry (with a maximum bias of $-6{ }^{\circ} \mathrm{C}$ ), while the Northeastern part was too wet (with a maximum bias of $8{ }^{\circ} \mathrm{C}$ ). WRF3-Noah showed the same patterns but had greater dry biases: $-2.1^{\circ} \mathrm{C}$ for California average dewpoint and as much as a $-8{ }^{\circ} \mathrm{C}$ bias in the southeastern part of the domain (Figure 4c). The PRISM California dewpoint had a slightly higher correlation with the WRF3-CLM3.5 predictions (0.77) than with those of Noah (0.70). While both models underestimated the dewpoint in the Central Valley (and overestimated its daily maximum temperature), WRF3-CLM3.5 was closer to observations. The warm and dry bias in the Central Valley is perhaps attributable to the lack of an irrigation mechanism in either land surface model; several studies suggest that the Central Valley midday summertime temperatures may be suppressed by $3-6^{\circ} \mathrm{C}$ due to irrigation (Kueppers et al. 2007; Kueppers et al. 2008; Lobell et al. 2008b; Weare and Du 2008).

The Sierra Nevada Mountains (Sierras) were generally biased cold during the daytime in both models (Figure 3c-d), which we attributed to excessive high-altitude precipitation compared with PRISM (Figure 4d-f). Precipitation predictions were biased wet nearly identically in the models (Figure 4e-f), with a California bias of $250 \mathrm{~mm}$ annually above the observed $570 \mathrm{~mm}$. For elevations greater than $2500 \mathrm{~m}$, the bias increased to $750 \mathrm{~mm}$ annually as compared with 820 mm observed, with a maximum bias of $2 \mathrm{~m}$ annually at points in the Sierras and North Coast. Excessive high-altitude precipitation was noted in a previous WRF evaluation for the present climate of California with boundary conditions from CCSM (Caldwell et al. 2009). This bias has been noted by the WRF community, and efforts are underway to understand and improve WRF's representation of high-altitude precipitation (Chin et al. 2009; Skamarock 2009). Because of this excessive precipitation, snow persisted at some high altitude gridcells throughout the melting season in WRF3-CLM3.5, accumulating in subsequent years. The snow melted by August each year in WRF3-Noah, which is roughly consistent with observations; however, given the unrealistically high precipitation, this may indicate only that deficiencies in the treatment of snow cover by the Noah land surface model noticed by some researchers (Feng et al. 2008; Jin and Miller 2007) are compensating for the commonly simulated excess Sierra Nevada precipitation in WRF and MM5 (Caldwell et al. 2009; Grubisic et al. 2005). In gridcells with 
excessive snow cover, the snow-vegetation-albedo feedback is substantially exaggerated in nonwinter seasons. Since these snow conditions are unlikely to be a realistic feature of future California climate, we do not analyze model predictions in the Sierras that were affected by this excessive predicted snow cover.

Both WRF3-Noah and WRF3-CLM3.5 captured the broad spatial and seasonal patterns in temperature throughout the region, as indicated by the high correlations (greater than 0.94 for both models) with both minimum and maximum air temperature observations (Table 2). Moreover, CLM incorporates most of the mechanisms responsible for near-surface temperature variation. As long as the biases are relatively constant with respect to vegetation and climate variability (additional experiments would be needed to confirm this), predictions of differences between simulations using the same model should be more accurate than the direct comparison with observations.

\subsection{Impact of Vegetation Change on Climate Change in California}

\subsubsection{Climate Change in the Absence of Vegetation Change (FCHV-HCHV)}

In the absence of vegetation change, predicted California regional climate warmed substantially between the scenario with historical climate and vegetation (HCHV) and with future (A2) climate and historical vegetation (FCHV) (Figure 5). Temperature increases were statistically significant throughout the domain at the 95\% confidence level and were broadly consistent with previous estimates (Cayan et al. 2008; Hayhoe et al. 2004) based on the same future climate model scenario. Temperature increases were more pronounced in the Sierra Nevada than along the coast, and in the North than in the South. Increases were also generally larger at midday than at night (not shown), and in the summer (Figure 5). In snow-free regions of California during the summer, both 4 PM $2 \mathrm{~m}$ air $\left(\mathrm{T}_{2}\right)$ and vegetation temperatures $\left(\mathrm{T}_{\mathrm{veg}}\right)$ increased by 3 to $5{ }^{\circ} \mathrm{C}$ (Figure 5e-f). ("Snow-free” is defined here and in what follows as lacking persistence of snow cover into June. Likewise, “vegetation temperature” is defined as the areaweighted average of the exposed leaf and stem temperature over all of the PFTs modeled in the gridcell, including the "bare ground" PFT, for which the "vegetation temperature" equals the temperature of the top soil layer.) Over most of the land portion of the model domain in the FCHV-HCHV comparison, warming of the climate boundary conditions resulted in a warming 
of similar magnitude in $2 \mathrm{~m}$ and vegetation temperatures. This prediction of similar effects on air and vegetation temperatures contrasts with the effects resulting from fine-scale heterogeneous vegetation change described below.

\subsubsection{Effects of Vegetation Change Alone (FCFV-FCHV)}

The effects of vegetation change alone on climate were estimated as the difference between the future climate, future vegetation (FCFV) and future climate, historical vegetation (FCHV) simulations. In these two future simulations, climate boundary conditions were the same, but the distribution of vegetation types was changed according to the MC1 projections (Figure 2).

Significant temperature differences due to vegetation change were found in much of California, with the largest differences generally in the summer (Figure 6). Temperature differences varied from negative to positive across the state, so peak gridcell and regional changes were of much larger magnitude than the statewide average (Figure 7a). However, due to the fine-scale heterogeneity of the vegetation change (Figure 2), with no region greater than about $100 \mathrm{~km}$ in length with the same vegetation change, even the largest $T_{2}$ changes were much smaller than typical $\mathrm{T}_{\text {veg }}$ changes (Figure $7 \mathrm{~b}-\mathrm{c}$ ). Indeed, $\mathrm{T}_{2}$ differences between FCFV and FCHV were sometimes larger at night than during the day (Figure 7b,f), despite the fact that the daytime surface energy budget appears to primarily control the vegetation temperature changes. This interaction probably occurred because the much stronger advection and boundary layer mixing during the day decoupled the local $2 \mathrm{~m}$ air temperature from the vegetation temperature immediately below it to a much greater extent than at night. Changes in surface roughness accompanying the vegetation change, causing changes in surface winds, exchange coefficients, and boundary layer mixing, may also have contributed to the closer coupling of vegetation and air temperature changes at night than during the day.

We highlight three regions with prominent imposed vegetation changes (Figure 2b) that experienced significant temperature changes that were not confounded by problematic precipitation and snow accumulation biases (see Section 3.1): the forest, woodland, and mixed grassland to annual $\mathrm{C}_{4}$-dominated grassland transition in the northern Central Valley (denoted as Transition A), the continental temperate coniferous forest to warm temperate / subtropical mixed forest and temperate mixed xeromorphic woodland transition in the Northwest corner of the state 
(Transition B), and the temperate arid shrubland to mixed grassland transition in the Northeast corner of the state (Transition C). Summary differences for the gridcells undergoing these transitions in these respective regions are presented in Table 3. In addition to these regions, numerous small patches are evident in the figures where the effects of vegetation on temperature are significant.

In the northern Central Valley transition from tree-containing and mixed grass ecosystems to $\mathrm{C}_{4}$ grass (Transition $\mathrm{A}$ ), vegetation change acted as a positive feedback, reinforcing regional climate change: summer $\mathrm{T}_{2}$ increased by $0-1{ }^{\circ} \mathrm{C}$ (Figure 6c), with $4 \mathrm{PM} \mathrm{T}_{\text {veg }}$ increasing by $0-5^{\circ} \mathrm{C}$ (Figure 7c). An increased Bowen ratio was largely responsible, as summer 4 PM sensible heat (SH) increased by an average of $5 \mathrm{~W} \mathrm{~m}^{-2}$ (with a range from -55 to $53 \mathrm{~W} \mathrm{~m}^{-2}$ ), and summer $4 \mathrm{PM}$ latent heat (LH) decreased by an average of $23 \mathrm{~W} \mathrm{~m}^{-2}$ (with a range of decrease from 9 to $70 \mathrm{~W}$ $\mathrm{m}^{-2}$ ) (Figure 7e-f). This result is consistent with the shift from trees and perennial grass to annual grass cover with much lower LAI in the summer, causing a decrease in evapotranspiration. Adding to this effect, $\mathrm{C}_{4}$ grasses tend to have greater water-use efficiency than $\mathrm{C}_{3}$ grasses, and have been shown to increase the Bowen ratio and cause local warming when replacing $\mathrm{C}_{3}$ grasses (Bounoua et al. 2002; Pongratz et al. 2006). The shift from latent to sensible heating was somewhat countered in the daytime boundary layer by statistically significant increases in the speed of the prevailing westerly winds, bringing in more cool air from the coast. The increase in wind may have resulted from both the increased surface temperature gradient between the coast and the valley, and the decreased surface roughness of the annual grass relative to the trees and perennial bunchgrass. Moreover, the surface temperature increase was also ameliorated by a small average increase in summer 4 PM albedo of 0.01 (with a range of -0.02 to 0.10 ) (Figure $7 \mathrm{~d}$ ), partially explaining why the magnitude of the decrease in latent heat exceeds the magnitude of the increase in sensible heat. While this transition is a significant one in the model, this vegetation change is likely to occur over a much smaller region than that modeled here, because much of this land is currently cultivated.

The Northwest (Transition B) and Northeast (Transition C) corners of the state experienced $\mathrm{T}_{2}$ decreases of 0 to $0.7^{\circ} \mathrm{C}$ from vegetation shifts, representing a negative climate feedback (Figure 6c). $4 \mathrm{PM} \mathrm{T}_{\text {veg }}$ decreased by 0.9 to $1.6{ }^{\circ} \mathrm{C}$ in the northwest and 1.2 to $2.1^{\circ} \mathrm{C}$ in the northeast. This cooling was caused primarily by a shift from sensible to latent heating in both 
regions (Figure 7e-f), and secondarily by increased albedo (Figure 7d). Very little change in cloudiness occurred statewide or in the transition regions (see Table 3, downward shortwave), so the albedo changes controlled the net shortwave budget at the surface.

In the Northwest (Transition B), there was a contrasting increase in summer $4 \mathrm{AM} \mathrm{T}_{2}$ of 0.3 to $0.8^{\circ} \mathrm{C}$ (Figure $7 \mathrm{~g}$ ) and $\mathrm{T}_{\text {veg }}$ of 0.4 to $1.0^{\circ} \mathrm{C}$ (Table 3). Simulated nighttime downward longwave radiation decreased, and therefore could not explain this response. Increased surface roughness (from a summertime value of $1.5 \mathrm{~m}$ to $1.9 \mathrm{~m}$ for Transition B) appears to have increased downward sensible heating by 1 to $5 \mathrm{~W} \mathrm{~m}^{-2}$ (with an average of $3 \mathrm{~W} \mathrm{~m}^{-2}$ ). Decreased nighttime soil evaporation (or increased condensation) due to the greater transpiration by trees during the day may also have contributed in some gridcells: 4 AM latent heat flux decreased by up to $1.3 \mathrm{~W} \mathrm{~m}^{-2}$ (though only an average of $0.2 \mathrm{~W} \mathrm{~m}^{-2}$ ).

The winter and spring temperature differences (Figure 6a-b) also show an area of cooling in a patch of the northwestern Sierras and an area of warming to the southeast of the cooling area. These temperature changes are associated with changes in albedo (not shown). These dynamics illustrate how the snow-albedo feedback could amplify the effects of vegetation change on the local temperature when vegetation is present over snow. Between FCHV and FCFV, an advance of forest into higher elevation in the southeast region resulted in further warming, contrasting with a warming-induced shift from dark boreal (subalpine) forest to lighter temperate (montane) forest in the northwest region that resulted in cooling (opposing the effect of large-scale climate warming). The large magnitude corresponding temperature differences in the summer and fall (Figure 6c-d and Figure 7a-c) are unrealistic because of the presence of extensive summer snow cover, due to the excess precipitation bias discussed previously.

To test the extent to which our predicted climate effects of vegetation change depend on large-scale climate conditions, we performed an analogous experiment under historical climate (HCFV-HCHV) conditions. Changes in temperature and surface fluxes were nearly identical to those discussed above in FCFV-FCHV, demonstrating that predicted regional climate effects of the transition from historical to future vegetation were not very sensitive to the global climate boundary conditions.

\subsubsection{Combined Effects of Changing Climate and Vegetation (FCFV-HCHV)}


A key question of this study is whether changes in regional vegetation distribution driven by climate change have the potential to significantly alter projections of California's regional climate that are based only on large-scale greenhouse gas forcing. A secondary question is whether vegetation-induced climate change is large enough to significantly alter projections for vegetation change itself (and therefore subsequent climate change). We compared the predicted annual mean temperature change due to large-scale forcing (FCHV-HCHV, Figure 8a) with that predicted from the combined effects of large-scale forcing and local vegetation change (FCFVHCHV, Figure 8b). (Differences between these two cases are equivalent to FCFV-FCHV, Figure 7a.)

In general, the magnitude of warming shows greater fine-scale heterogeneity once the patchy predictions of vegetation change are included. In particular, enhanced warming is visible in the northern Central Valley, while warming is suppressed in a $\sim 2000 \mathrm{~km}^{2}$ area in the northeast corner of the state and in areas of the Sierra. (We interpret any net cooling between HCHV and FCFV as an unrealistic artifact of our incomplete feedback loop: we do not update the MC1 vegetation scenarios in response to the changes in regional climate predicted here using these scenarios.) In areas where the vegetation change makes an insignificant contribution to projected temperature change, our analysis did not necessarily find no effect of vegetation, just no net effect, with the potential for competing processes (e.g., shift in the Bowen ratio vs. change in albedo) that cancel each other's temperature effect. The results are roughly consistent with the magnitudes of vegetation feedback found in a study using a coarser resolution model with simpler vegetation representations (Diffenbaugh 2005), which found changes of up to $3^{\circ} \mathrm{C}$ in surface temperature. However, we predicted a stronger coupling of vegetation properties with vegetation temperature (see 3.2.2) than with $2 \mathrm{~m}$ air temperature: the small scale of typical spatially coherent vegetation changes we imposed allowed local changes in the surface energy budget to be partially washed out by advection, especially during the day time.

We estimated the relative importance of the vegetation feedbacks in California as the "feedback ratio" between temperature change ( $2 \mathrm{~m}$ air and vegetation) due to vegetation change alone and temperature change due to both vegetation change and large-scale forcing (FCFVFCHV)/(FCFV-HCHV) (Figure 9). A positive ratio indicates positive feedback, and a negative 
ratio indicates negative feedback for situations where $|\mathrm{FCHV}-\mathrm{HCHV}|>|\mathrm{FCFV}-\mathrm{FCHV}|$ (e.g., where the follow-on response of temperature to the vegetation change is smaller than the temperature change in the absence of vegetation change; this was true except for several isolated cells in snow-free regions which we ignored here). Across California, model predictions indicated that in snow-free regions under SRES-A2, between -30\% and 30\% of the total summer mean air temperature increase resulted from projected vegetation change (Figure 9a). Variations within this range depended on the vegetation type change, and the vegetation feedback was less important on an annual average (Figure 9b) than in the summer.

Vegetation temperatures themselves were substantially more sensitive to the projected vegetation change, with vegetation change representing from less than $-100 \%$ to $70 \%$ of the total summer warming in snow-free regions, with large magnitudes found in extensive regions throughout the state (Figure 9c). Assuming that vegetation change is at least as sensitive to the vegetation temperature as the surface $2 \mathrm{~m}$ air temperature, these results imply there are extensive regions throughout the state that have a very strong vegetation-climate coupling. In such regions, accurate prediction requires coupled two-way feedback experiments where dynamic vegetation models adjust to the changes in regional climate that are caused by simulated changes in vegetation.

\subsection{Afforestation}

The afforestation (FCFAV) vegetation distribution features three regions where afforestation is prescribed over relatively large areas: the Northeastern corner of the state (Transition D), the Sierras, and Owen's Valley (directly east of the Sierras) (Figure 2c), though results from the Sierras and the downwind Owen's Valley are confounded by anomalously high predicted winter precipitation and snow accumulation in the Sierras (Section 3.1). The dominant cover type change in these regions was from shrubland to temperate coniferous forest. As in the previous cases, the greatest temperature changes occurred during the summer (Figure 10), although there were also significant changes in the annual average $T_{2}$ (Figure 11a).

A summer cooling was observed in Transition $\mathrm{D}$ of 0.2 to $1.2^{\circ} \mathrm{C}$ in $\mathrm{T}_{2}$ (Figure $10 \mathrm{c}$ ) and 2.0 to $3.7^{\circ} \mathrm{C}$ in $4 \mathrm{PM} \mathrm{T}_{\text {veg }}$ (Figure 11c). Other snow-free areas showed decreases in summer temperature from afforestation scattered throughout the state (either in a gridcell with 
afforestation or immediately downwind), especially at night, when changes in boundary layer mixing and advection were least confounding: the summer statewide $\mathrm{T}_{2}$ decreased by $0.2^{\circ} \mathrm{C}$ at 4 AM (Table 3). In the Owen's Valley east of the Sierras, there was a similar summer cooling at night (Figure 11g) and for $4 \mathrm{PM} \mathrm{T}_{\text {veg }}$ (Figure 11c), while a slight warming occurred in $\mathrm{T}_{2}$ during the day (Figure 11b). The daytime warming was possibly due to advection from high altitude gridcells to the west that experienced a (probably unrealistic) large summer warming due to a large decrease in albedo; this albedo decrease depended on the unrealistic high altitude summer snow cover in the FCFV simulation discussed previously.

The areas experiencing temperature decreases also experienced large increases in latent heating: the $4 \mathrm{PM}$ summer latent heating increased by a range of 26 to $71 \mathrm{~W} \mathrm{~m}^{-2}$ in Transition D (with an average of $50 \mathrm{~W} \mathrm{~m}^{-2}$ ) (Figure 11f). The $4 \mathrm{PM}$ sensible heat flux change was spatially heterogeneous and varied from -30 to $45 \mathrm{~W} \mathrm{~m}^{-2}$ (with an average of $10 \mathrm{~W} \mathrm{~m}^{-2}$ ) (Figure 11e), while the $4 \mathrm{PM}$ upward longwave flux change ranged from -8 to $-16 \mathrm{~W} \mathrm{~m}^{-2}$ (with an average of $11 \mathrm{~W} \mathrm{~m}^{-2}$ ). The fact that the latent heat increased by $\sim 50 \mathrm{~W} \mathrm{~m}^{-2}$ without an accompanying large decrease in the sum of sensible and longwave fluxes can be accounted for by the decrease in 4 PM summer albedo of 0.03 to 0.12 for Transition D (Figure 11d), and potentially by an increased surface exchange coefficient due to the increased surface roughness, which reduced the temperature gradient between the surface and the lower atmosphere. The albedo decrease was partially offset by increased cloudiness over the afforested areas, although this was not statistically significant for any gridcell; shortwave radiation reaching the surface decreased by 4 $\mathrm{W} \mathrm{m} \mathrm{m}^{-2}$ for Transition D.

The winter season in the Sierras showed an increase in $\mathrm{T}_{2}$ of up to $1.2^{\circ} \mathrm{C}$ (Figure 10a) as well as large albedo decreases of up to 0.4 (not shown). Previous studies have also found winter warming when modeling increased forest cover in areas with persistent winter snow cover (Diffenbaugh 2005; Lamptey et al. 2005; Snyder et al. 2004a). Whether winter warming would accompany afforestation on a significant spatial scale in California may depend on the extent and depth of snow cover in afforested regions.

In addition to the temperature and surface flux changes mentioned, suggestive but not statistically significant increases in precipitation of $\sim 100 \mathrm{~mm} \mathrm{y}^{-1}$ (Figure 11h) occurred over the 
northeastern afforested region (Transition D), mostly due to increasing large scale precipitation rather than convective precipitation. Longer runs and additional sensitivity experiments would be needed to validate this result and to understand the mechanisms responsible.

To evaluate how the climate effects of afforestation depended on the initial vegetation distribution and climate boundary forcing, we repeated the above simulations with afforestation imposed over the historical vegetation distribution and with historical climate (i.e., HCHAVHCHV). The most salient difference between this comparison and the one under future climate and vegetation cover (FCFAV - FCFV) is that the winter warming area in the Sierras is much smaller when afforesting under historical climate and vegetation conditions. This difference occurs because dark forest is already present in the historical vegetation in this area. We note that this region also experienced cooling between FCHV and FCFV because of the opposite shift to lighter vegetation. The areas that undergo similar vegetation change between HCHV $\rightarrow$ HCHAV and FCFV $\rightarrow$ FCFAV had similar changes in temperature. Consequently, as found in the other historical climate sensitivity experiment (HCFV-HCHV), we found that the effect of vegetation on regional climate was relatively insensitive to the imposed lateral boundary conditions.

The predicted decrease in annual mean temperature for snow-free regions as a result of afforestation is in contrast with some previous modeling studies that found that the decrease in albedo was more important than changes in evapotranspiration and cloudiness, resulting in a net warming of the near-surface atmosphere (Bala et al. 2007; Betts et al. 2007; Bounoua et al. 2002; Gibbard et al. 2005; Snyder et al. 2004a). (For the purposes of this discussion, a study examining a decrease in forest cover from a baseline is interpreted analogously to the opposite of an increase in forest cover from the baseline.) However, our results are consistent with other studies that have found net cooling due to increased ET and cloudiness as a result of increased temperate forest cover (Jackson et al. 2005; Juang et al. 2007; Ramankutty et al. 2006; Roy et al. 2003; Strack et al. 2008). Even some of the studies that found a net warming predicted some contrasting seasonal and regional effects, in which shortwave warming from afforestation dominated in winter months in snowy regions and evaporative cooling dominated in summer months (Diffenbaugh 2005; Snyder et al. 2004a). 
Further research is warranted on the complex tradeoffs between shortwave radiation and evapotranspiration effects, along with the possibility of changes in cloudiness, surface exchange coefficients, and regional circulation, particularly in light of policies promoting afforestation as a mitigation strategy for anthropogenic climate change. We note that the California Air Resources Board is currently investigating afforestation policies under Assembly Bill 32 of 2005.

Additional research is also needed to determine where afforestation is feasible without extensive management in a future warmer climate. In our simulations, we included afforestation in areas that MC1 projected to be occupied by non-forest under future climate. In particular, the Owen's Valley east of the Sierras may be too dry to support forest under future climate. Additional studies of afforestation potential should incorporate climate change itself into characterization of suitable sites, and consider local and regional climate feedbacks, particularly in the context of evolving snow cover.

\subsection{Limitations and Scope for Further Research}

In addition to those mentioned above, there are several ways in which this study could be expanded and improved to develop better scenarios of regional climate and vegetation change in California. Further model development is warranted to reduce biases in the representation of current climate, especially in high-altitude precipitation, and in daily minimum temperature over inland areas. The inclusion of $\mathrm{CO}_{2}$ concentration increases for future climate in the modeled regional atmosphere would expand our results to include the atmospheric longwave effects of $\mathrm{CO}_{2}$ on net surface radiation and the physiological effects of $\mathrm{CO}_{2}$ on photosynthesis and transpiration, potentially influencing regional-scale biogeophysical feedbacks. Using larger domains and longer simulation times would allow investigation of changes in large-scale circulation and the frequency of extreme events, although the patchy nature of the vegetation change modeled here may make these changes less likely. Including a full ensemble of possible vegetation changes and large-scale climate forcing scenarios would better characterize the uncertainty in the predictions and potentially increase confidence in the results. Because of the interest in afforestation as a strategy to sequester $\mathrm{CO}_{2}$, it is important to clarify why existing studies do not agree on the sign of the net local temperature effects of increased temperate forest cover. The realism of the vegetation scenarios used in this study is limited by the lack of land use changes besides afforestation, lack of limitation on plant species migration, and the lack of a 
dynamic feedback between vegetation distributions and local climate. Finally, additional field measurements could improve the plant parameterizations used here.

\section{Summary and Conclusions}

In this study, WRF3 was coupled to CLM3.5, and both WRF3-CLM3.5 and the existing WRF3-Noah models were evaluated against observed historical California regional climate. WRF3 reproduced the temporal and spatial variation in California's climate fairly well, but significant improvements are needed in the simulation of high altitude precipitation and nighttime temperatures: large biases with similar spatial patterns occurred with both land surface models, of up to $10{ }^{\circ} \mathrm{C}$ for daily minimum temperature and up to $2 \mathrm{~m} \mathrm{yr}^{-1}$ for high altitude precipitation.

We used WRF3-CLM3.5 to investigate feedbacks to climate change in California from climate-change-driven shifts in vegetation. The heterogeneous nature of predicted vegetation shifts in this ecologically and topographically complex region resulted in net local temperature changes that varied in sign at fine spatial scales and insignificant changes in precipitation. Unlike large-scale climate change, changes in vegetation distributions may have a greater impact on vegetation temperature than near-surface air temperature; in snow-free regions less impacted by precipitation biases, changes in vegetation cover were responsible for up to $70 \%$ of the total increase in vegetation temperature under a $21^{\text {st }}$ century climate change scenario, while changes in vegetation cover were only responsible for up to $30 \%$ of the total increase in $2 \mathrm{~m}$ air temperature. The Northern Central Valley is particularly vulnerable to exacerbation of climate change due to an increased Bowen ratio associated with a shift from trees and perennial grasses to annual $\mathrm{C}_{4}$ grasses, although continued widespread cultivation may limit natural vegetation feedbacks in this region. In contrast, both the northwest and northeast corners of the state may experience mitigation of climate warming from increases in albedo and decreases in Bowen ratio associated with a shift to deciduous trees and mixed grassland. The predominant vegetation-mediated mechanisms driving temperature change (albedo and Bowen ratio change) can counteract each other and be accompanied by changes in cloudiness, surface roughness, and circulation, all of which contribute to the complexity of predicting climate change at fine special scales. 
Efforts to improve predictions of climate change at local to regional scales are needed as policies promoting intentional land cover change are considered. In areas of California free of summer snow cover such as the Northeast, afforestation may have a regional cooling effect on climate because of decreases in Bowen ratio and possible increases in cloudiness, reinforcing the climate benefit of the land cover change. However, such a benefit may not be realized if afforestation is planned for areas not likely to support trees under future climate, for example east of the Sierras.

These predictions improve on past studies by using a more sophisticated land surface model, PFTs customized for the region, and a published scenario for afforestation. However, they should be confirmed with additional research that addresses the biases in the current model, uses more realistic vegetation change scenarios that include anthropogenic land use change, and includes the radiative and physiological effects of increased $\mathrm{CO}_{2}$ at the regional scale. Future regional projections of climate and vegetation change should consider climate-vegetation feedbacks and distinguish between surface air temperature changes and vegetation temperature changes. 


\section{Acknowledgements}

The authors thank Ron Neilson (Oregon State University), Jim Lenihan (U.S.D.A. Forest Service), and Sandra Brown (Winrock International) for providing scenarios of vegetation change in California, Sebastien Biraud (Lawrence Berkeley National Lab) and Ramona Butz (U.S.D.A. Forest Service) for helping convert various files to common resolutions and projections, and Norman L. Miller (Lawrence Berkeley National Lab) for his contribution to the WRF2-CLM3.0 coupling work. Simulations were performed on computers at the University of California, Merced and at Lawrence Berkeley National Lab. The computers were maintained by Joseph Norris in Merced and Krishna Muriki and Susan James in Berkeley, whose help was invaluable throughout the simulation process. Two anonymous reviewers also provided detailed comments that allowed us to substantially improve the clarity of this article. This work was funded by the California Energy Commission’s PIER Energy-Related Environmental Research Program (but it does not necessarily represent the views of the Energy Commission, their employees, or the State of California, nor has it been reviewed by Energy Commission or the University of California, nor is any liability assumed for this information or its use). This research was also supported by the Office of Biological and Environmental Research of the U.S. Department of Energy, under Contract No. DE-AC02-05CH11231, as part of the Atmospheric Radiation Measurement Program. 
Figures

Figure 1: Parent (outer) and nest (inner) domains used to evaluate the WRF3-CLM3.5 coupling.

Figure 2: Vegetation distributions used in the feedback analysis: (a) historical (HV); (b) future (FV); (c) future + afforestation (FAV); and (d) historical + afforestation (HAV). Panel (e) shows selected shifts between HV and FV: to mixed evergreen (blue), grassland (green), and shrubland (red). Panel (b) shows the location of Transitions A, B, and C, and panel (c) shows the location of Transition $D$. Transition $A$ is from $37-40^{\circ} \mathrm{N}$ and $120-122.5^{\circ} \mathrm{W}$ and includes gridcells switching from forest, woodland, or mixed grassland to $\mathrm{C}_{4}$-dominated grassland for $\mathrm{HV}$ to $\mathrm{FV}$; Transition $\mathrm{B}$ is from $40-42^{\circ} \mathrm{N}$ and $122-124^{\circ} \mathrm{W}$ and includes gridcells switching from continental temperate coniferous forest to warm temperate / subtropical mixed forest and temperate mixed xeromorphic woodland for HV to FV; Transition C is from $40.5-42^{\circ} \mathrm{N}$ and $120-121^{\circ} \mathrm{W}$ and includes gridcells switching from temperate arid shrubland to mixed grassland for $\mathrm{HV}$ to FV; Transition $D$ is from $40-42^{\circ} \mathrm{N}$ and $120-122^{\circ} \mathrm{W}$ and includes gridcells switching to continental temperate coniferous forest for FV to FAV.

Figure 3: Time-averaged (1982-1991) daily maximum and minimum $2 \mathrm{~m}$ air temperatures for model evaluation. Panels a-d are daily maximum temperature: (a) interpolated PRISM data; (b) WRF3-CLM3.5 predictions; (c) WRF3-CLM3.5 biases with respect to monthly PRISM data; and (d) WRF3-Noah biases with respect to monthly PRISM data. Panels e-g are daily minimum temperature: (e) interpolated PRISM data; (f) WRF3-CLM3.5 biases with respect to monthly PRISM data; and (g) WRF3-Noah biases with respect to monthly PRISM data.

Figure 4: Time-averaged (1982-1991) dewpoint temperature and annual precipitation for model evaluation. Panels a-c are dewpoint temperature: (a) interpolated PRISM data; (b) WRF3-CLM3.5 evaluation biases with respect to monthly PRISM data; and (c) WRF3Noah biases with respect to monthly PRISM data. Panels d-f are annual precipitation: (d) interpolated PRISM data; (e) WRF3-CLM3.5 evaluation biases with respect to monthly PRISM data; and (f) WRF3-Noah biases with respect to monthly PRISM data.

Figure 5: Differences between future and historical climate (both with historical vegetation). Panels a-d are seasonal mean $2 \mathrm{~m}$ air temperature: (a) winter; (b) spring; (c) summer; and (d) fall. Panels e-f are 4 PM summer differences for (e) 2 m air temperature; 
and (f) vegetation temperature. All changes are statistically significant at the $95 \%$ confidence level. Differences $>6^{\circ} \mathrm{C}$ primarily occurred in the regions of unrealistic snow accumulation and were truncated.

Figure 6: Differences between future and historical vegetation (both with future climate) for seasonal mean $\mathbf{2} \mathrm{m}$ air temperature: (a) winter; (b) spring; (c) summer; and (d) fall. All colored gridcells represent changes statistically significant at the $95 \%$ confidence level. Differences of magnitude greater than $1{ }^{\circ} \mathrm{C}$ primarily occurred in the regions of unrealistic snow accumulation and were truncated.

Figure 7: Differences between future and historical vegetation (both with future climate) for (a) annual mean $2 \mathrm{~m}$ air temperature; (b) summer 4 PM $2 \mathrm{~m}$ air temperature; (c) summer 4 PM vegetation temperature; (d) summer 4 PM albedo; (e) summer 4 PM sensible heat; (f) summer 4 PM latent heat; and (g) summer 4 AM 2 m air temperature. All colored gridcells represent changes statistically significant at the $\mathbf{9 5 \%}$ confidence level, except for albedo (d). Differences were truncated to the minimum and maximum shown, with larger magnitude differences primarily occurring in the regions of unrealistic snow accumulation. Note the larger colorbar scale for (g) than the other $\mathbf{2} \mathbf{m}$ air temperature plots.

Figure 8: Differences in annual mean $2 \mathrm{~m}$ air temperature (a) between future and historical climate (both with historical vegetation); and (b) between future climate / future vegetation and historical climate / historical vegetation. Differences $>6^{\circ} \mathrm{C}$ primarily occurred in the regions of unrealistic snow accumulation and were truncated.

Figure 9: "Feedback ratio" for (a) summer daily mean; and (b) annual mean $2 \mathrm{~m}$ air temperature; and for (c) summer 4 PM vegetation temperature. The ratios were calculated as (FCFV-FCHV)/(FCFV-HCHV). Gridcells where the net summertime temperature change FCFV-FCHV $\leq 0$ were prescribed a ratio of -1 . Ratios were restricted to magnitude less than 1; larger magnitude ratios primarily occurred in the regions of unrealistic snow accumulation.

Figure 10: Differences between future and future + afforestation vegetation (both with future climate) for seasonal mean $2 \mathrm{~m}$ air temperature: (a) winter; (b) spring; (c) summer; 
and (d) fall. All colored gridcells represent changes statistically significant at the $95 \%$ confidence level. Differences of magnitude greater than $1^{\circ} \mathrm{C}$ primarily occurred in the regions of unrealistic snow accumulation and were truncated.

Figure 11: Differences between future and future + afforestation vegetation (both with future climate) for (a) annual mean 2 m air temperature; (b) summer 4 PM 2 m air temperature; (c) summer 4 PM vegetation temperature; (d) summer 4 PM albedo; (e) summer 4 PM sensible heat; (f) summer 4 PM latent heat; (g) summer 4 AM 2 m air temperature; and (h) annual precipitation. All colored gridcells represent changes statistically significant at the $95 \%$ confidence level, except for albedo (d) and precipitation (h). Differences were truncated to the minimum and maximum shown, with larger magnitude differences primarily occurring in the regions of unrealistic snow accumulation. Note the larger colorbar scale for (g) than the other $2 \mathbf{m}$ air temperature plots. 


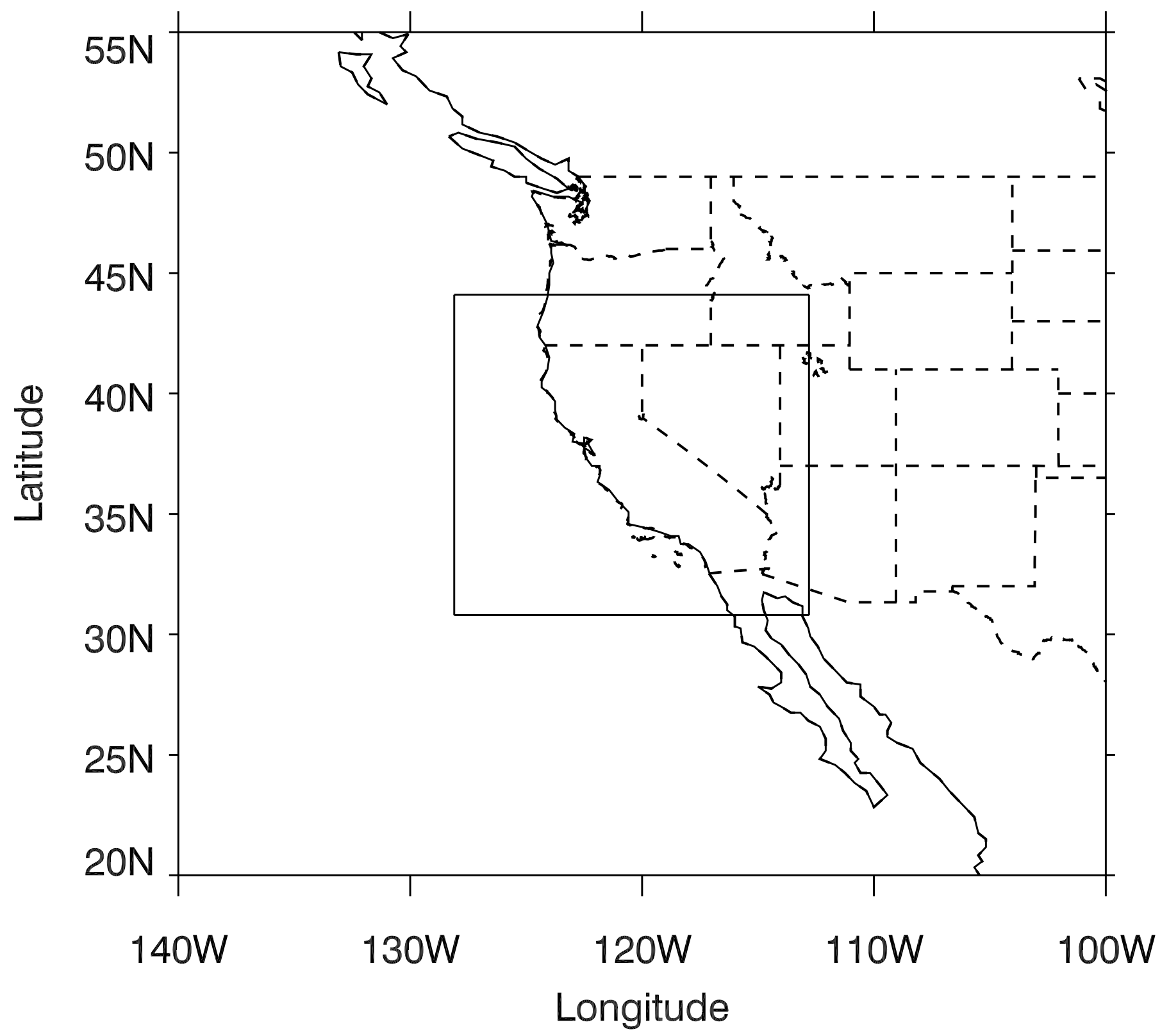

Figure 1 
Figure 2

(a) HV

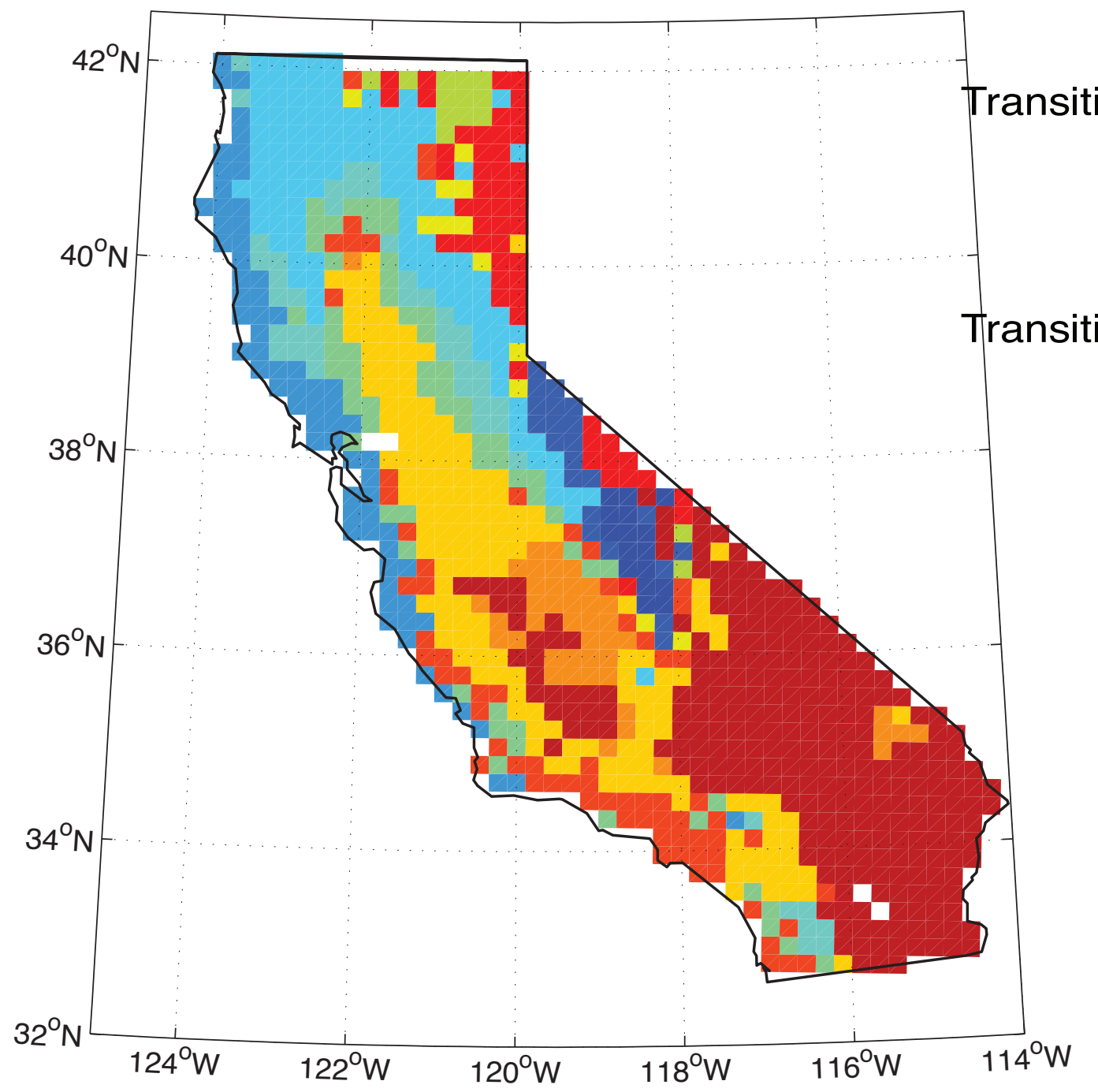




\section{(b) FV}

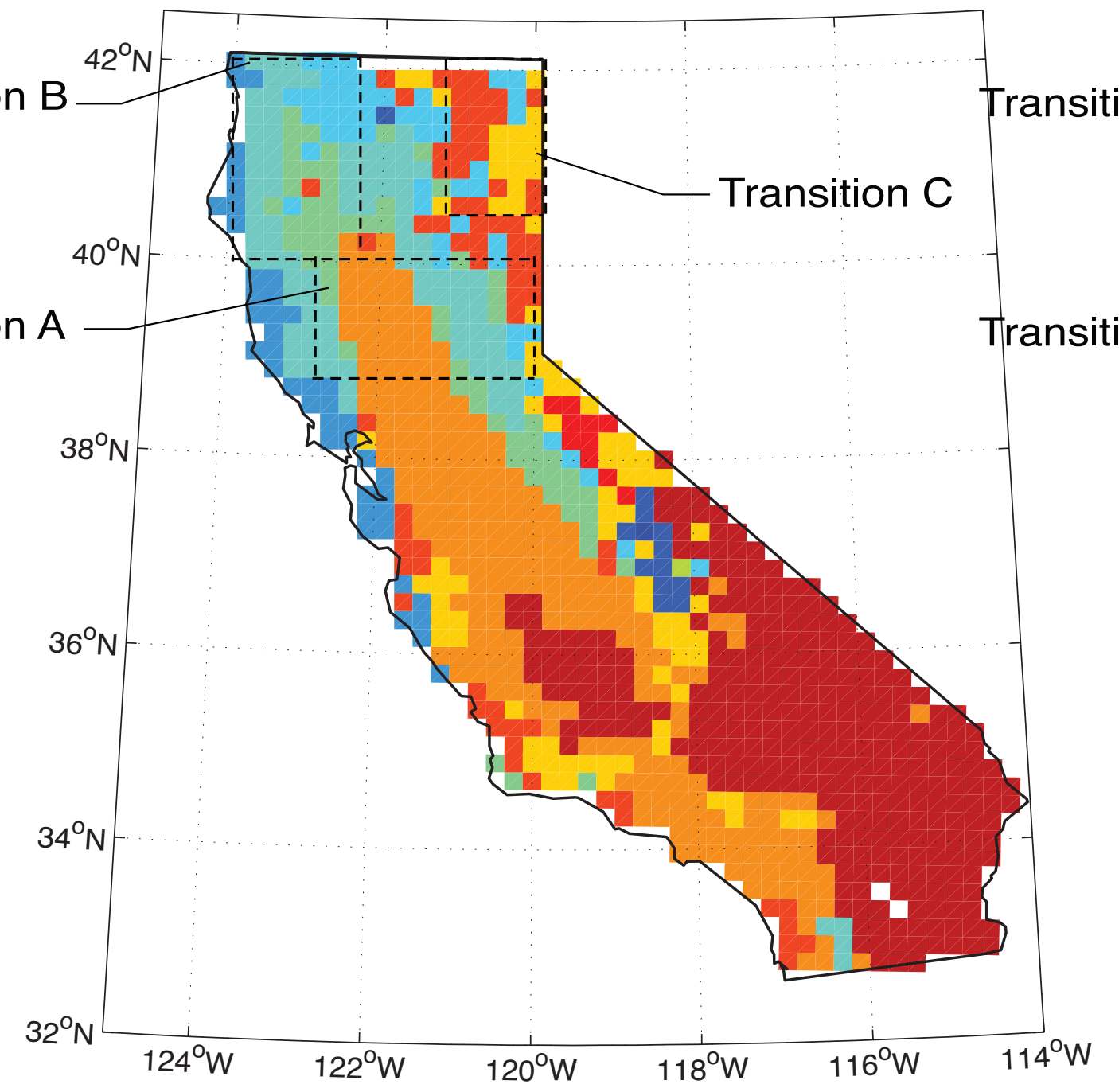




\section{(e) Selected HV $\rightarrow$ FV Shifts}

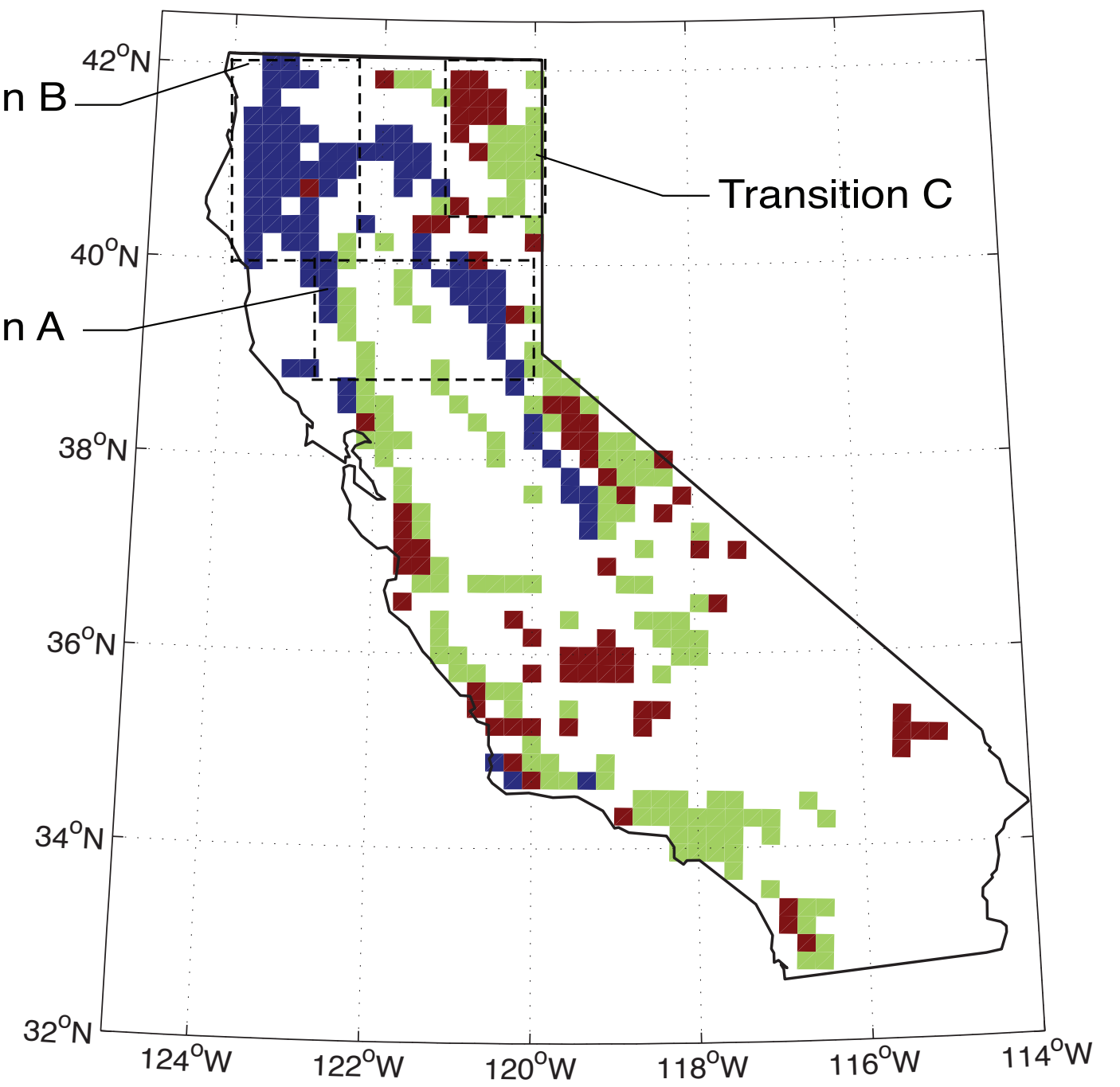




\section{(c) FAV}

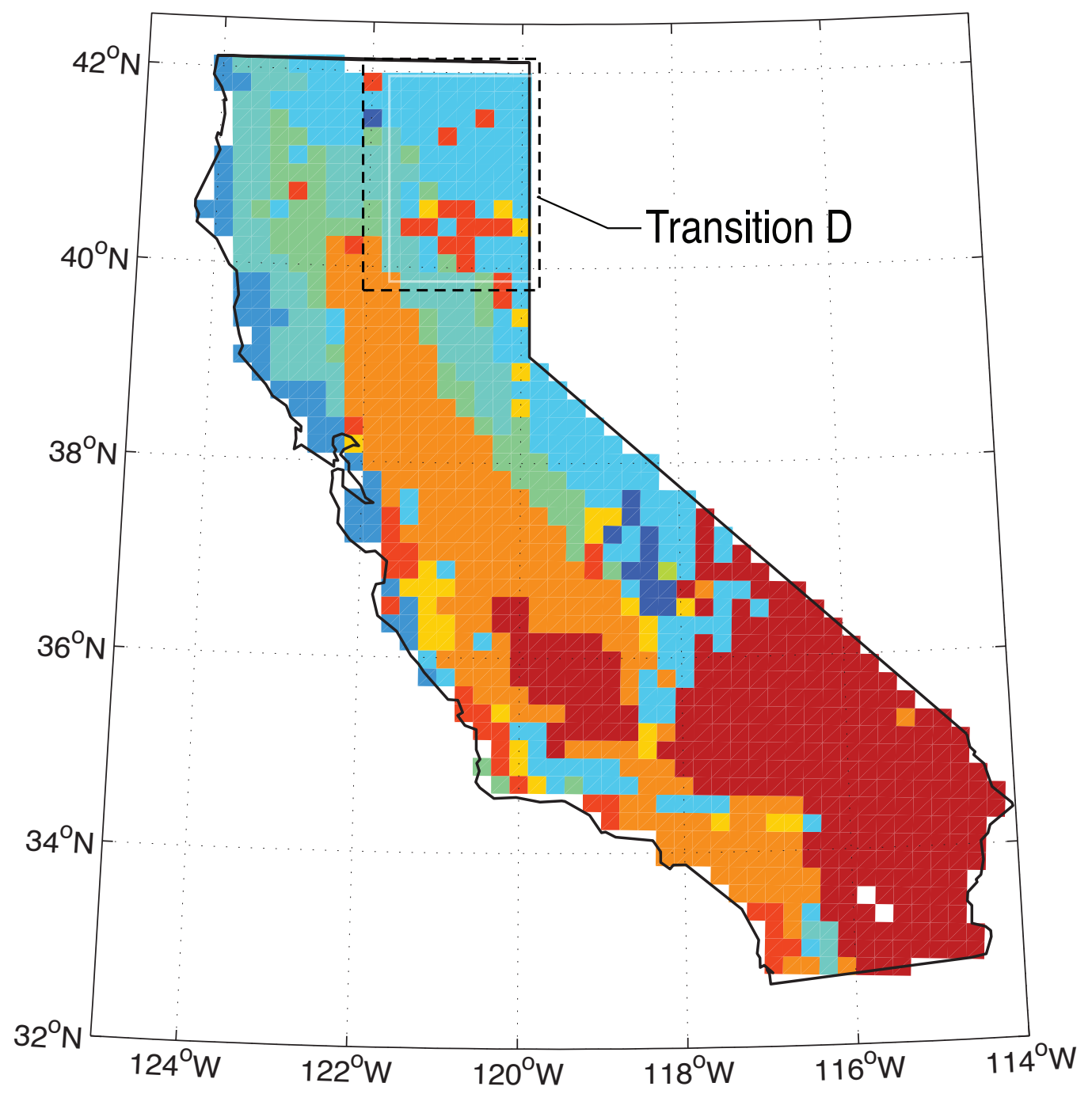


(d) HAV

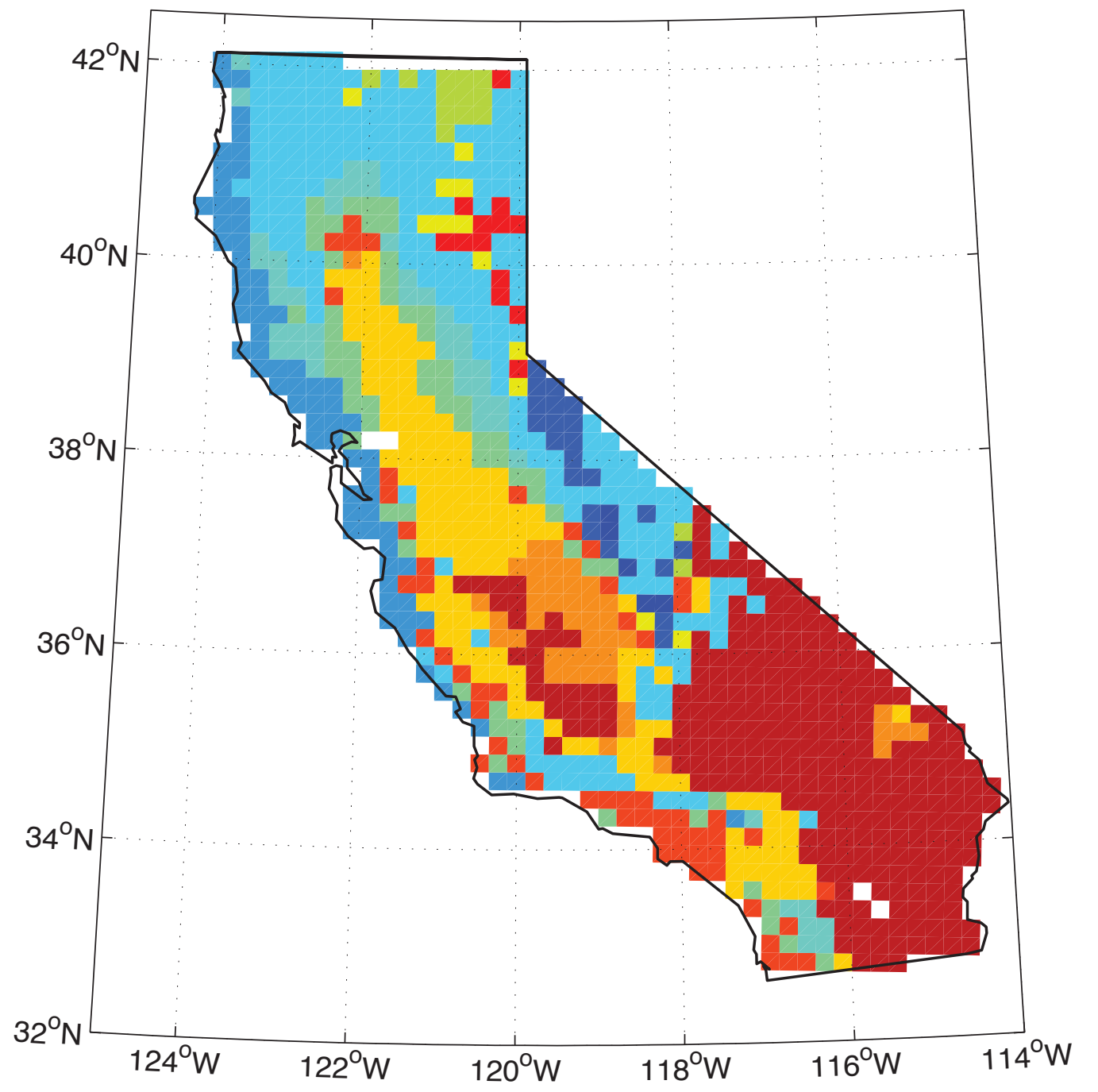


Tundra

Boreal Forest

Maritime Temperate Coniferous Forest Continental Temperate Coniferous Forest

Warm Temp./Subtrop. Mixed Forest

Temperate Mixed Xeromorphic Woodland Temperate Conifer Xeromorphic Woodland

Temperate Conifer Savanna

C3 Perennial Grassland

C4 Annual Grassland

Mediterranean Shrubland

Temperate Arid Shrubland

Subtropical Arid Shrubland

Wetland 
Figure 3

(a) $\mathrm{T}_{2}$ max., PRISM

${ }^{\circ} \mathrm{C}$

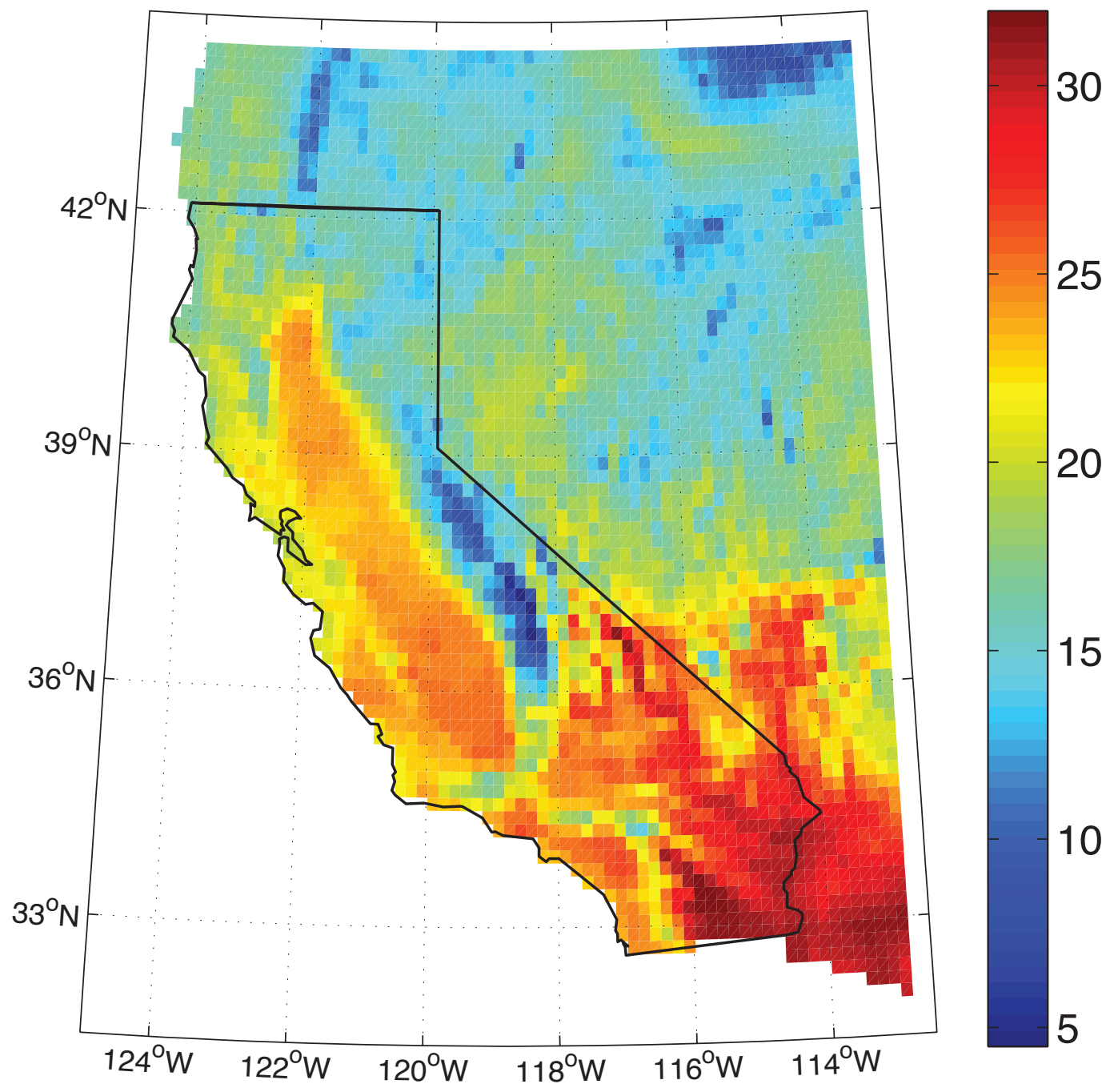


(b) $\mathrm{T}_{2}$ max., CLM (Absolute)

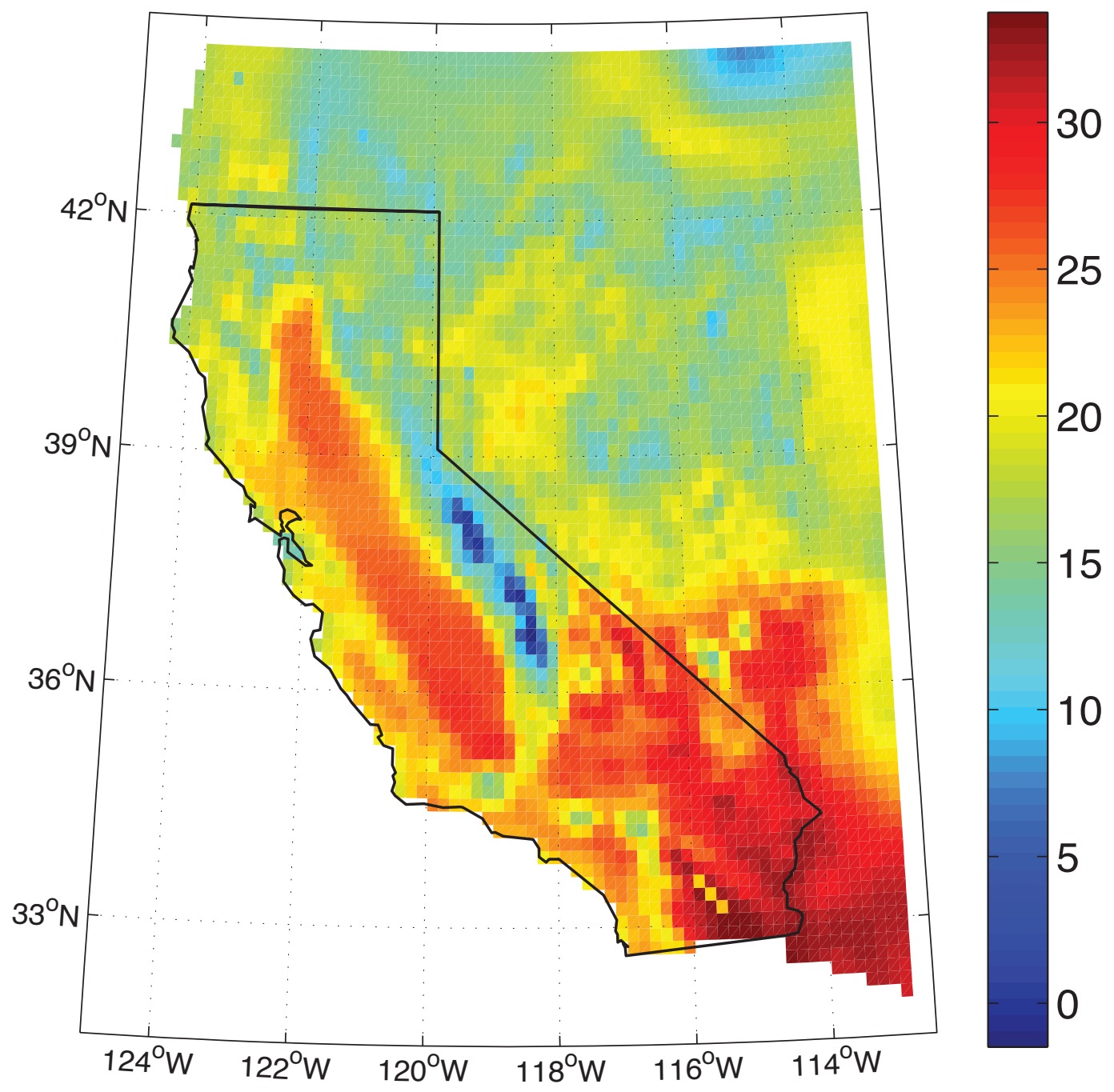


(c) $\mathrm{T}_{2}$ max., CLM Bias

${ }^{\circ} \mathrm{C}$

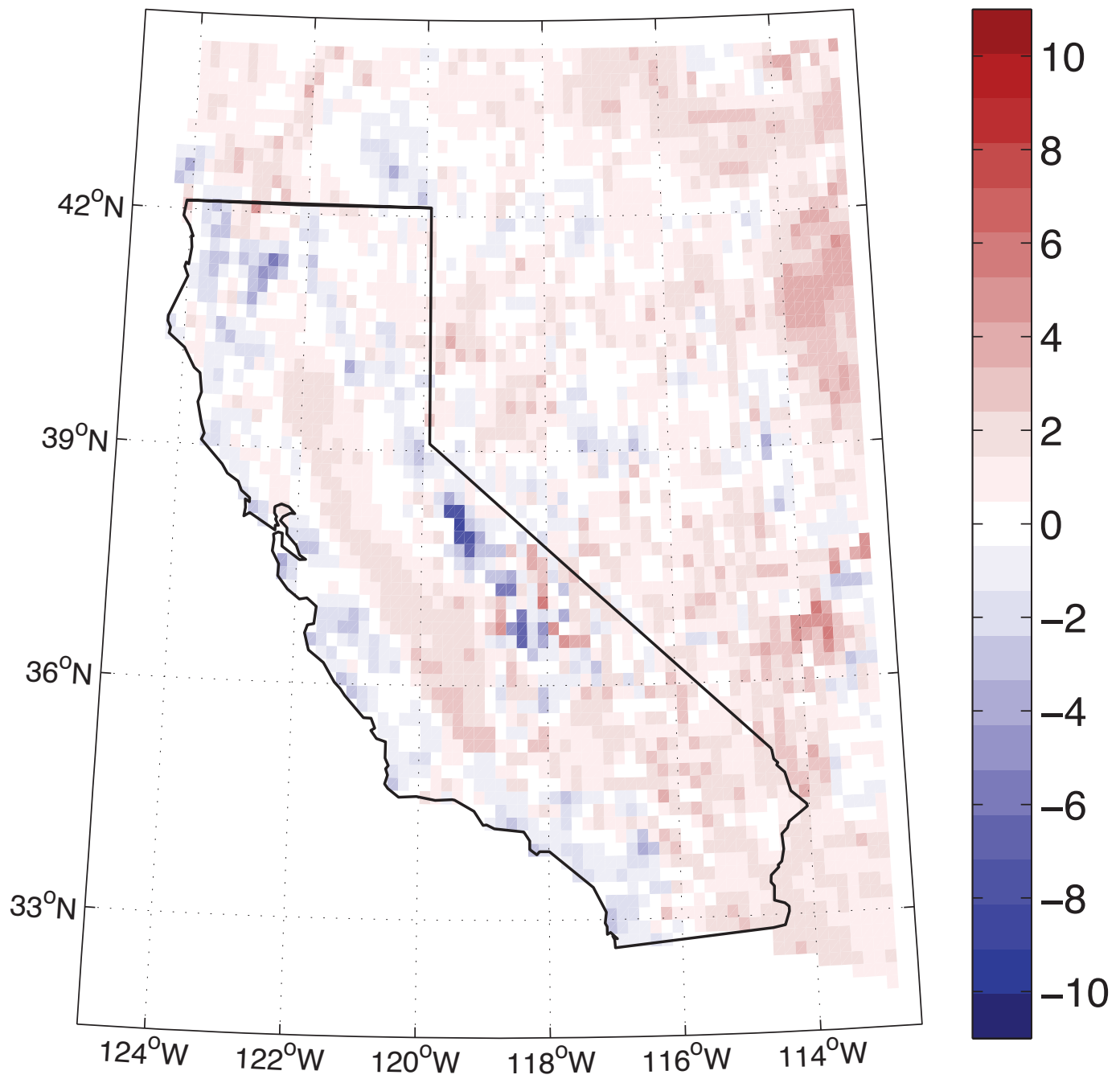




\section{(d) $\mathrm{T}_{2}$ max., Noah Bias}

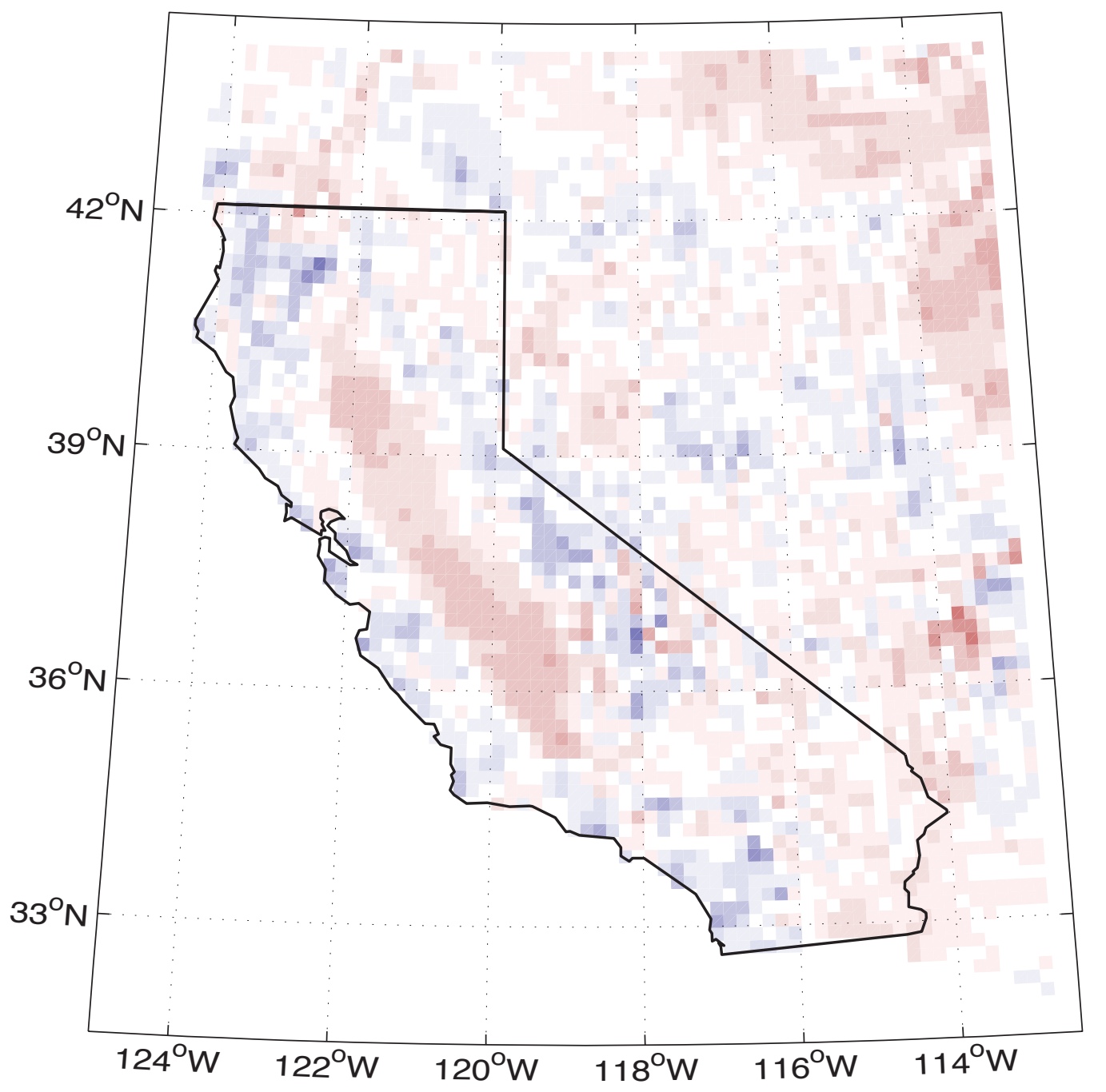




\section{(e) $T_{2}$ min., PRISM}

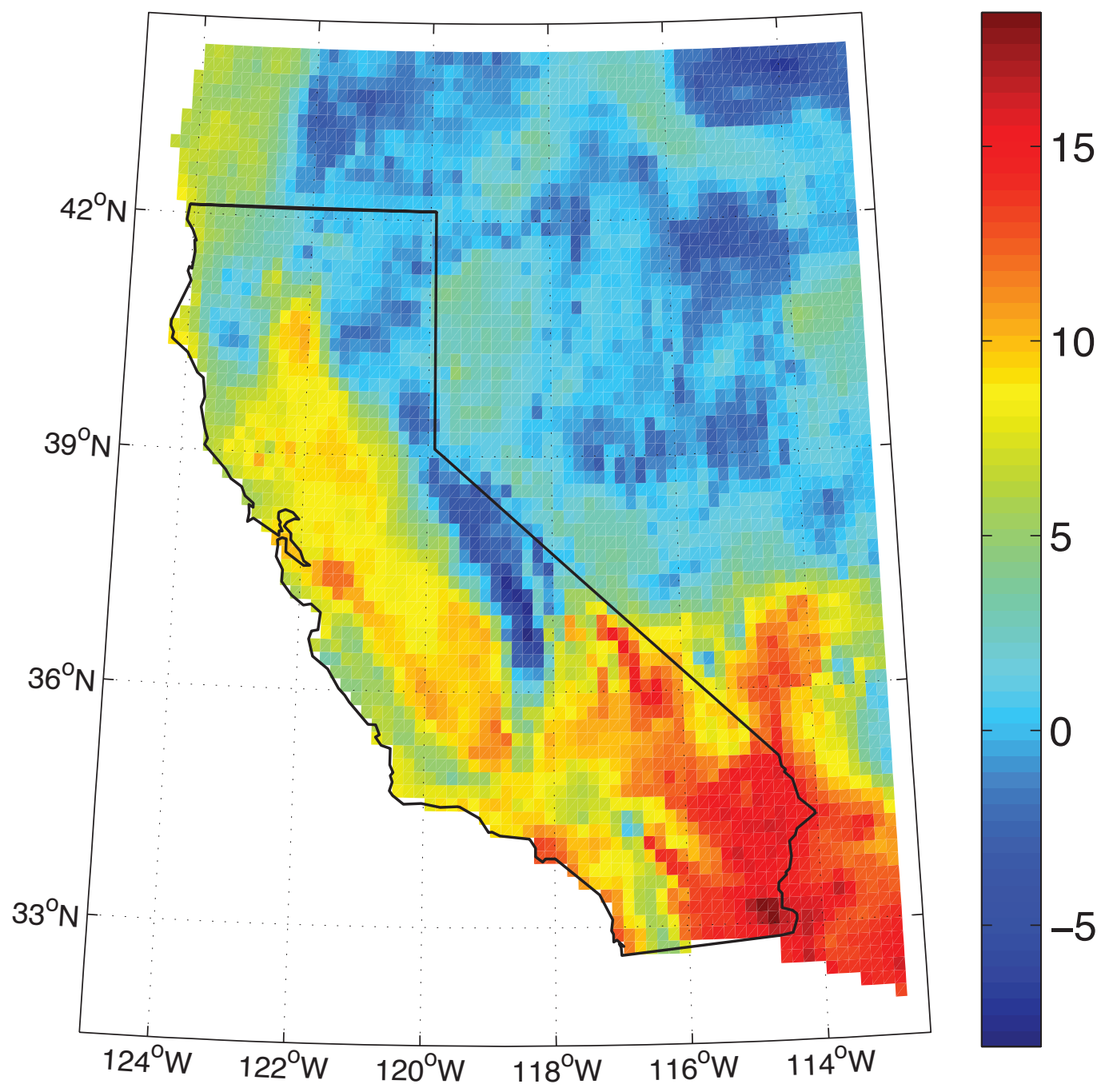




\section{(f) $\mathrm{T}_{2}$ min., CLM Bias}

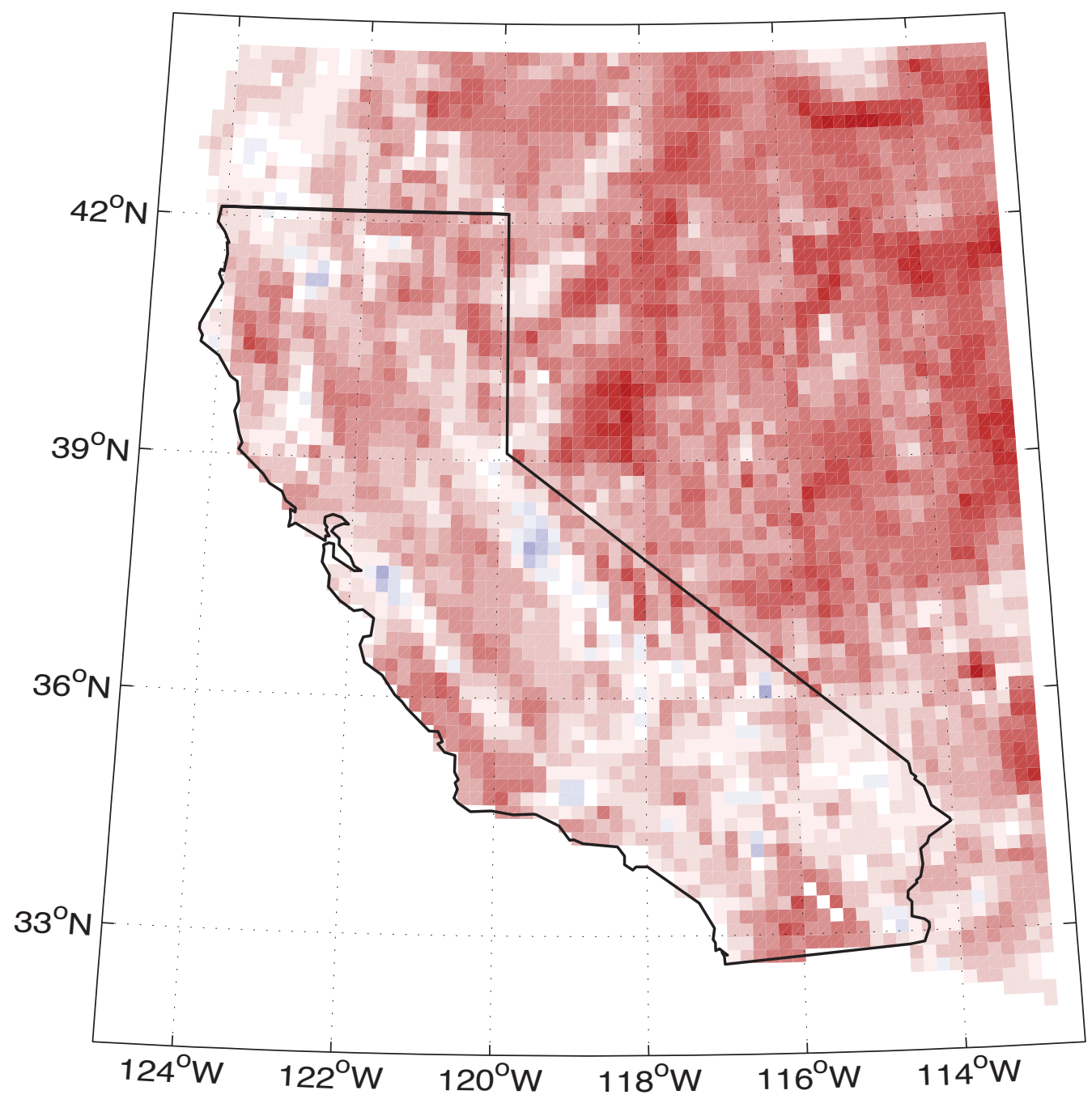




\section{(g) $T_{2}$ min., Noah Bias}

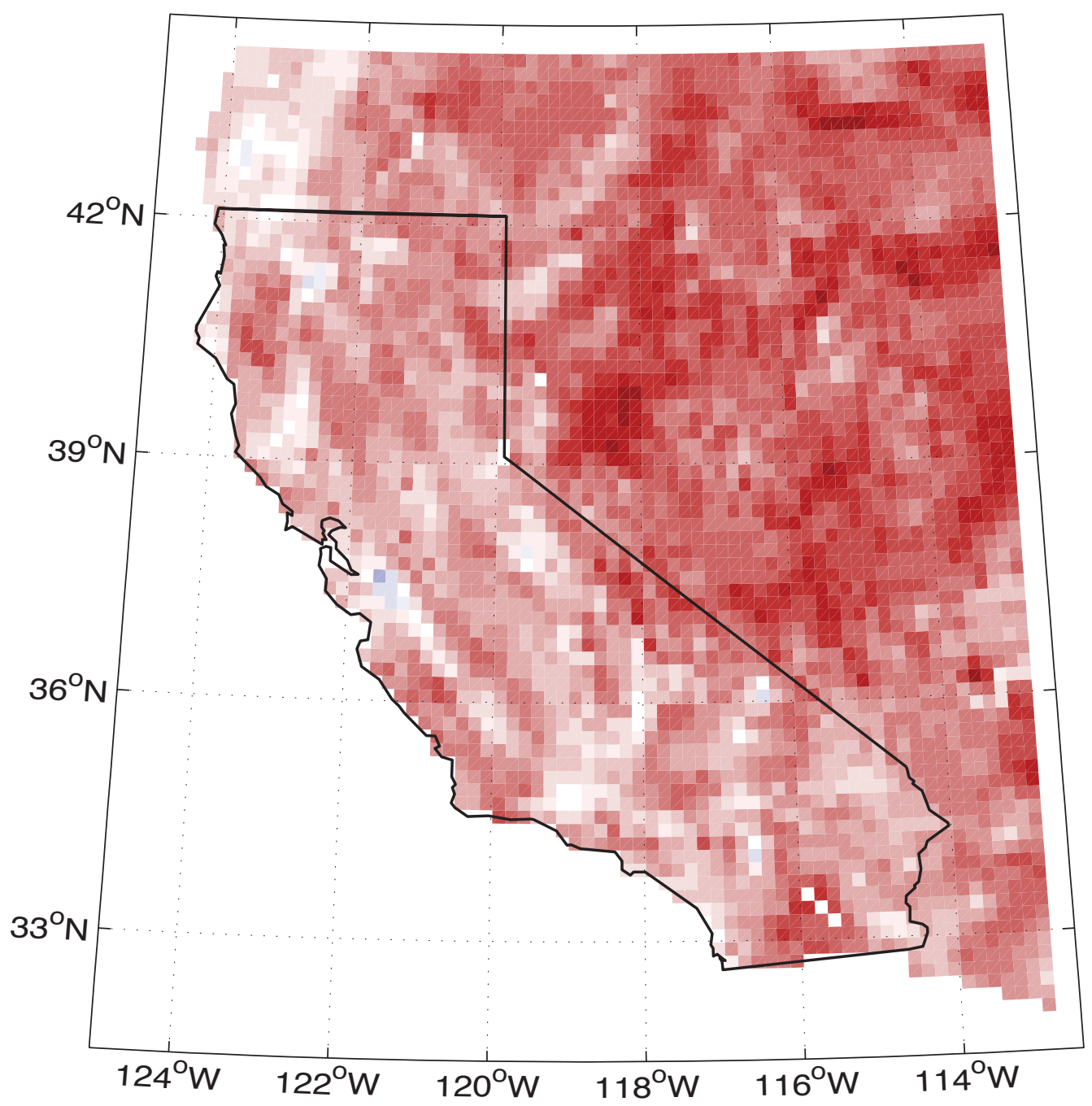


(a) Dewpoint Temp., PRISM

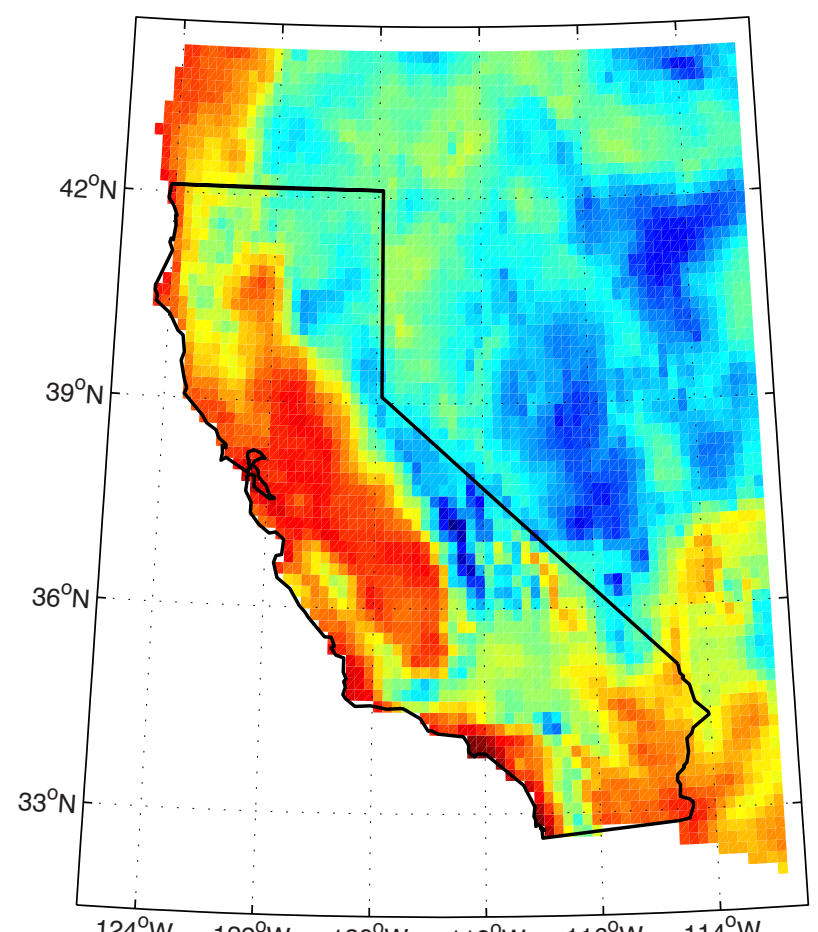

(d) Precipitation, PRISM

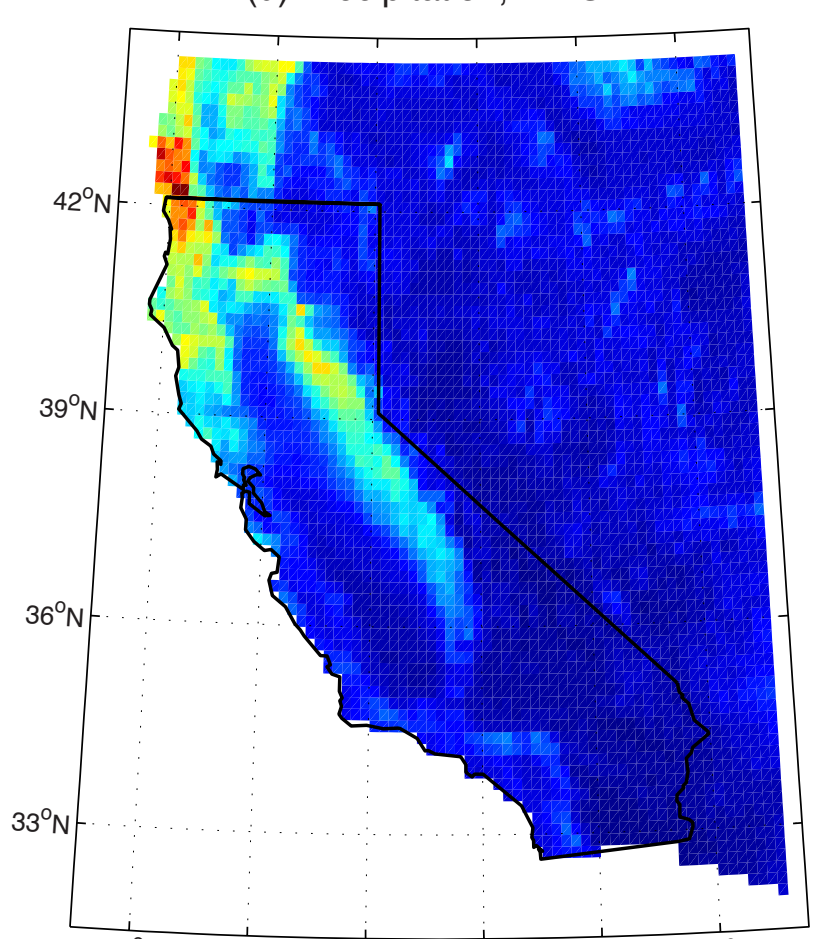

$\begin{array}{cccccc}124^{\circ} \mathrm{W} & 122^{\circ} \mathrm{W} & 120^{\circ} \mathrm{W} & 118^{\circ} \mathrm{W} & 116^{\circ} \mathrm{W} & 114^{\circ} \mathrm{W}\end{array}$
${ }^{\circ} \mathrm{C}$

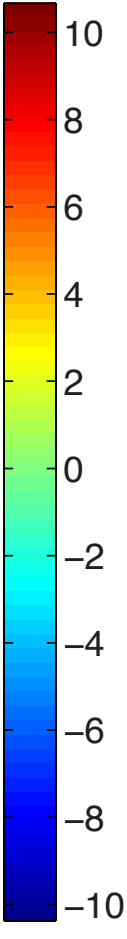

$\mathrm{m} \mathrm{y}^{-1}$

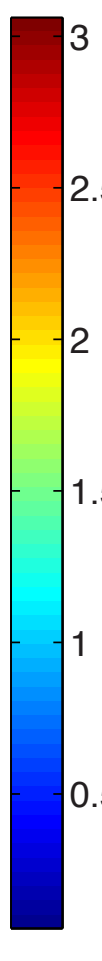

(b) Dewpoint Temp., CLM Bias

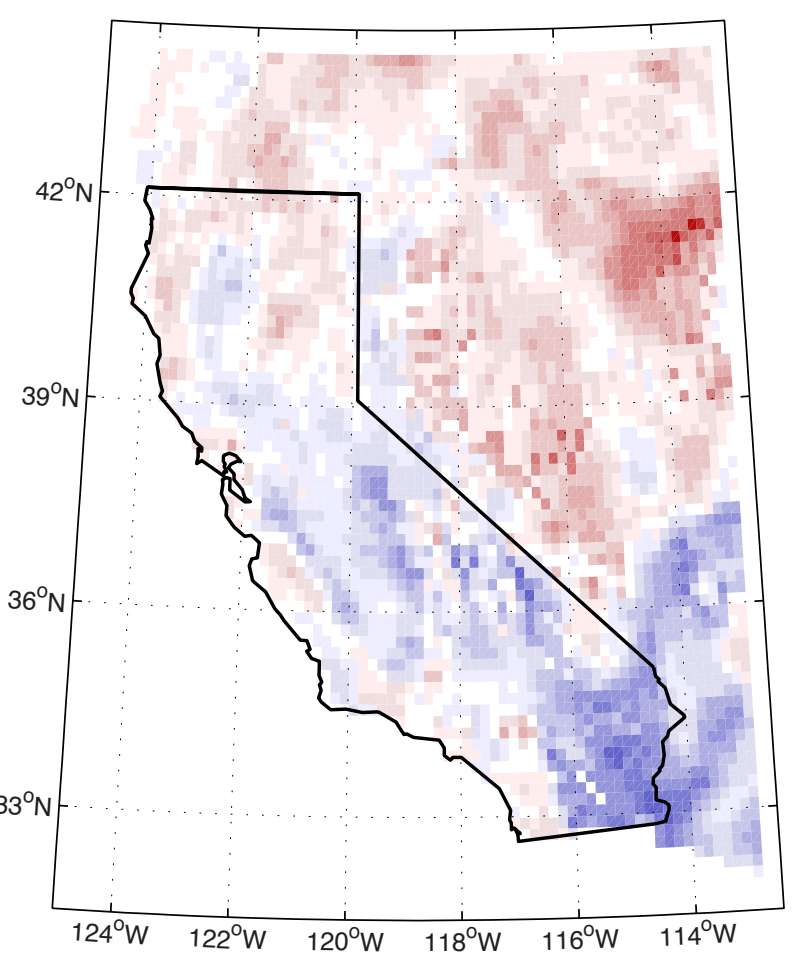

(e) Precipitation, CLM Bias

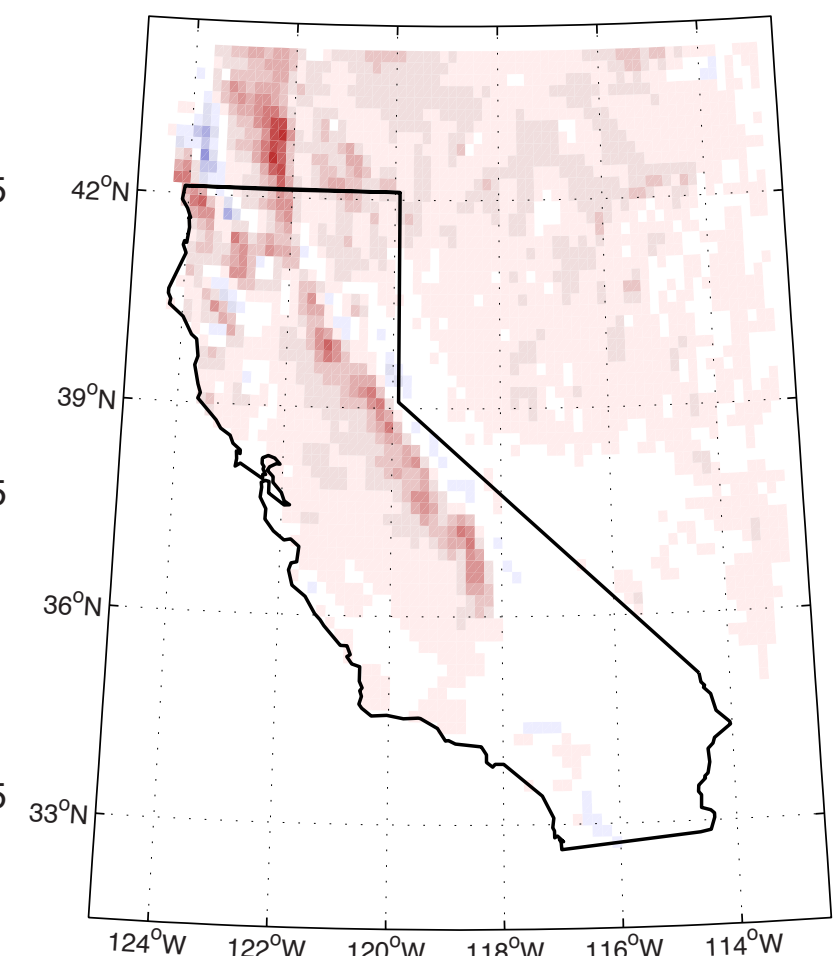

(c) Dewpoint Temp., Noah Bias

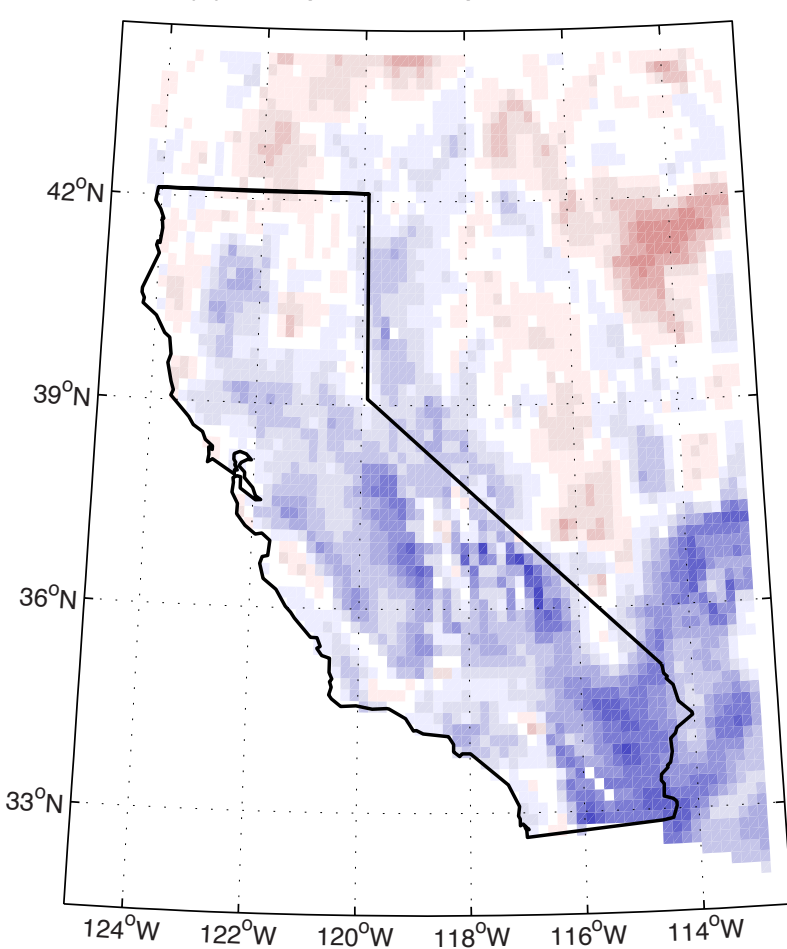

(f) Precipitation, Noah Bias

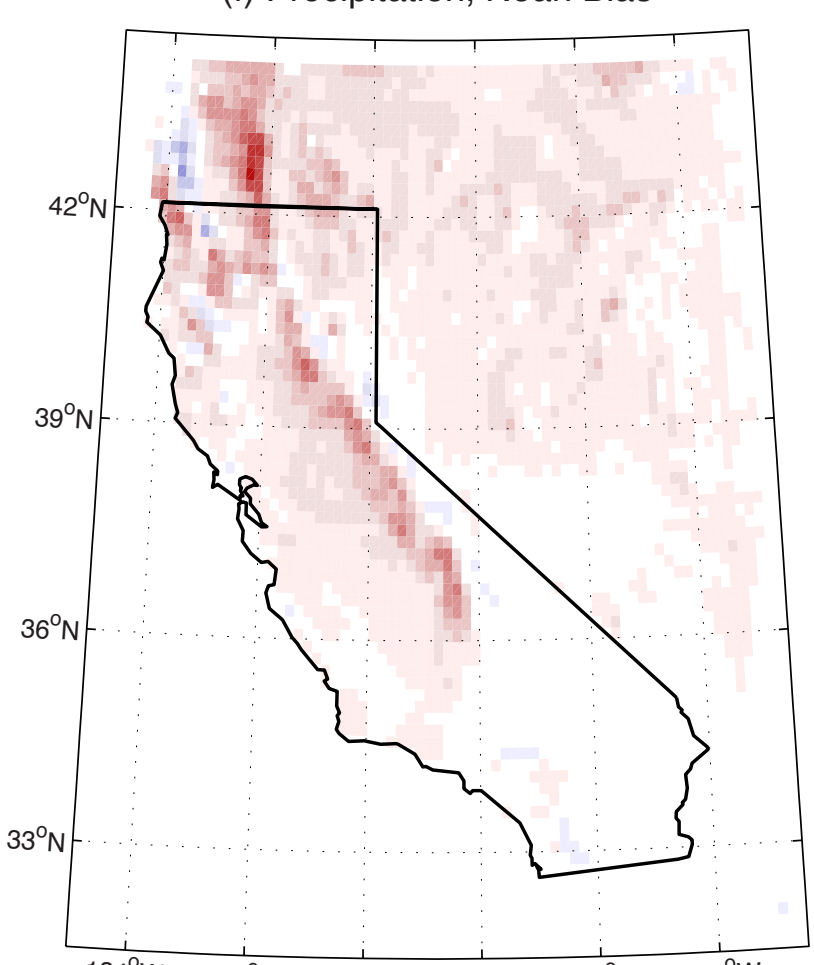

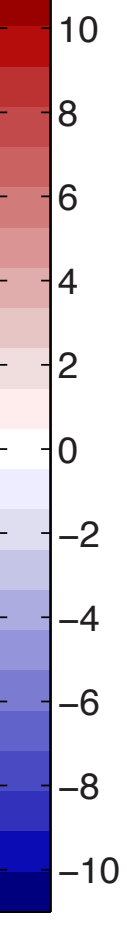

$\mathrm{m} \mathrm{y}^{-1}$

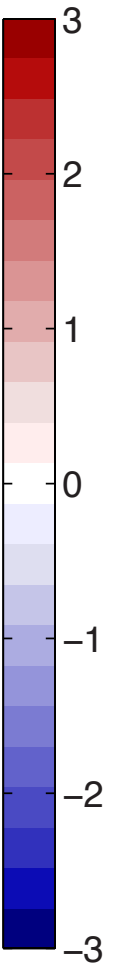




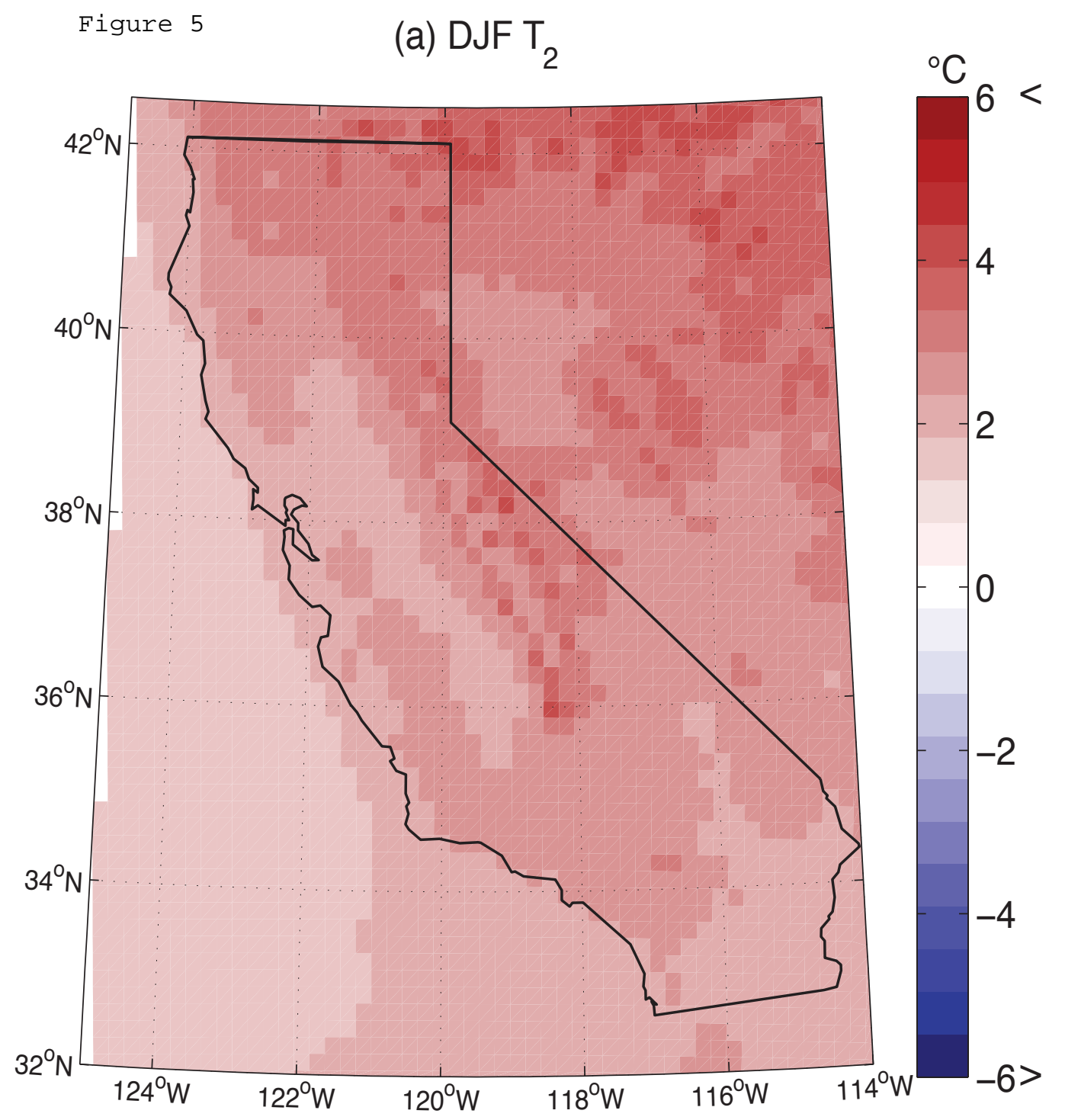


(b) $\mathrm{MAM} \mathrm{T}_{2}$

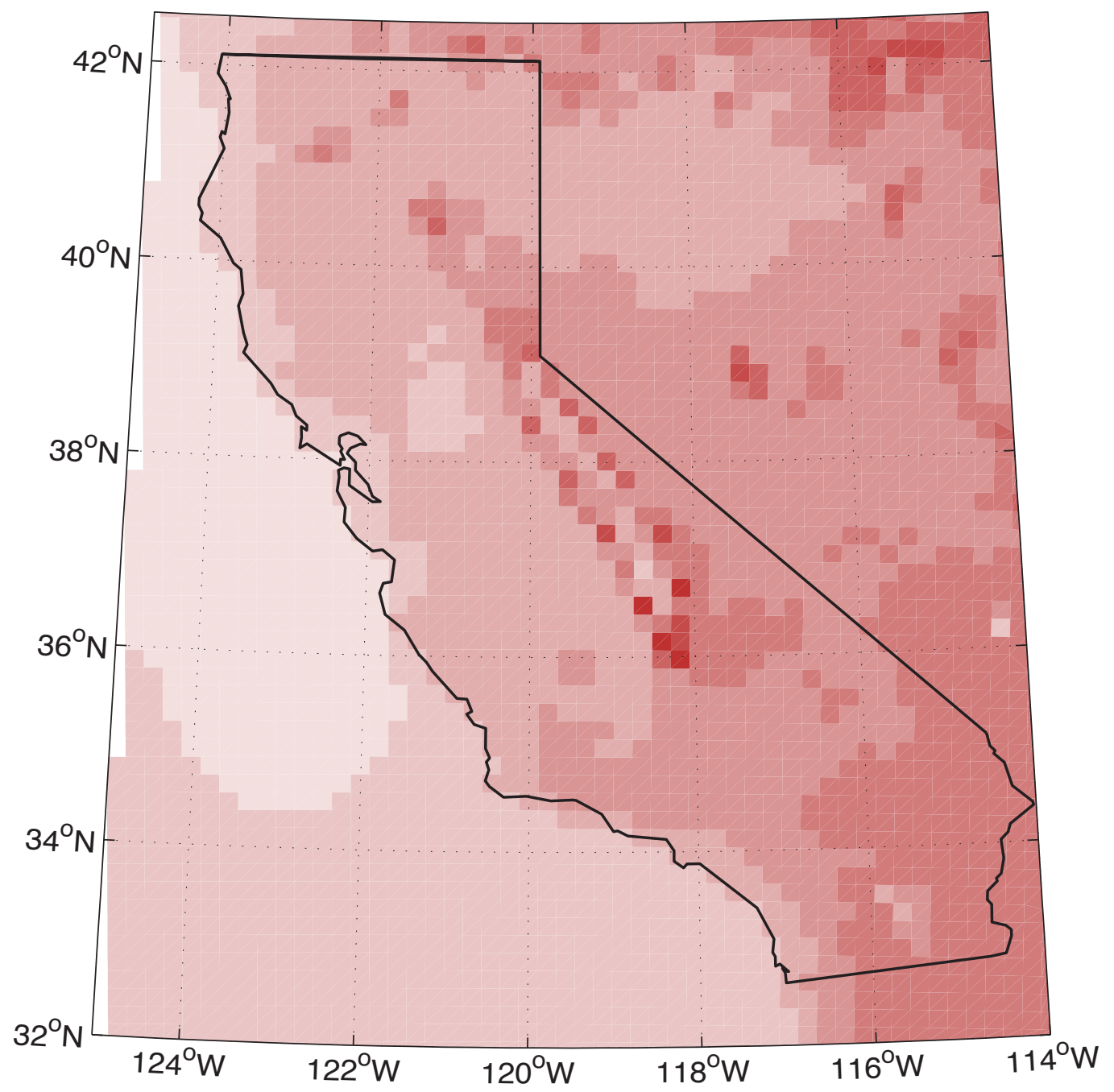




\section{(c) JJA T 2}

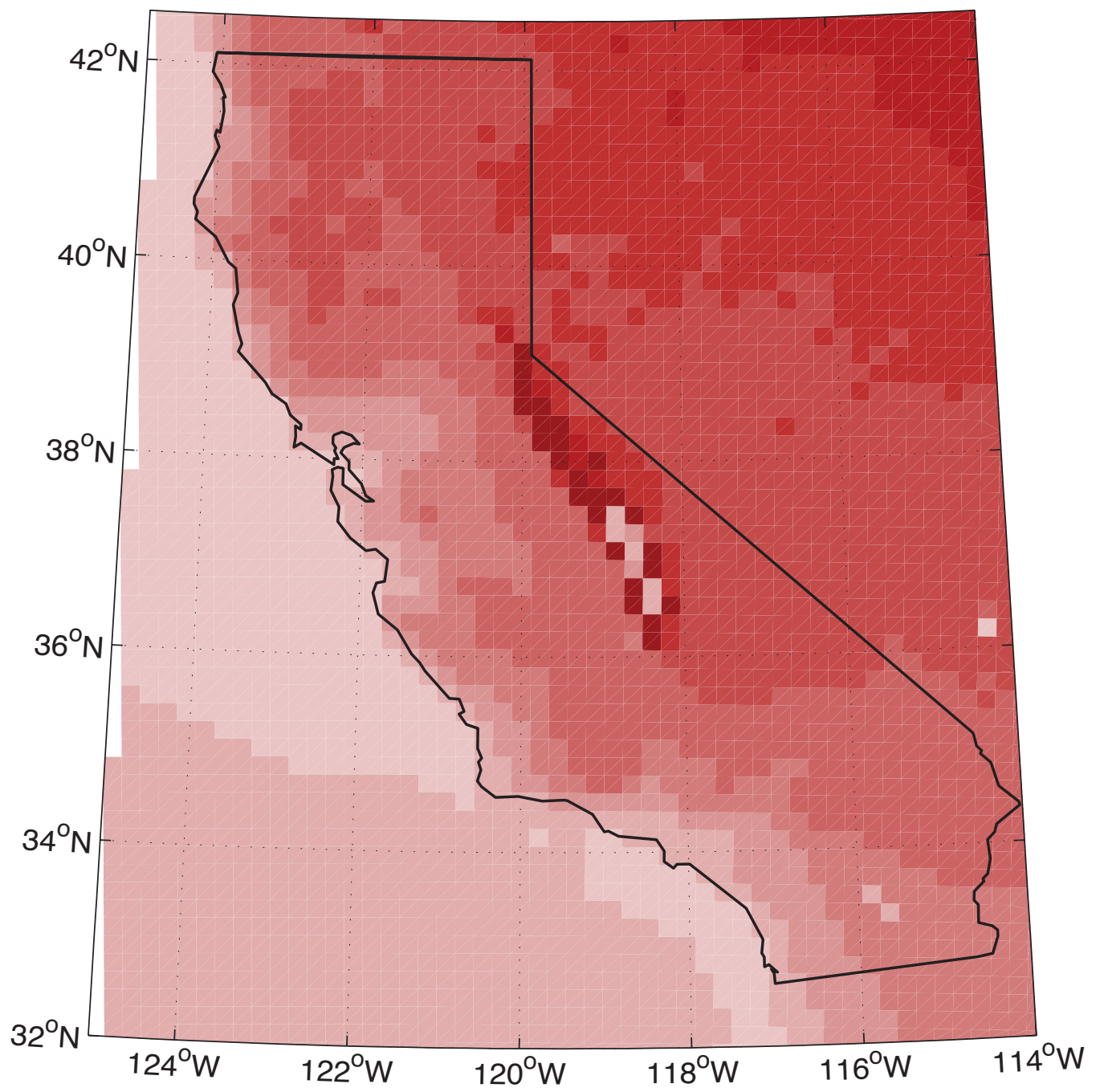




\section{(d) $\mathrm{SON} \mathrm{T}_{2}$}

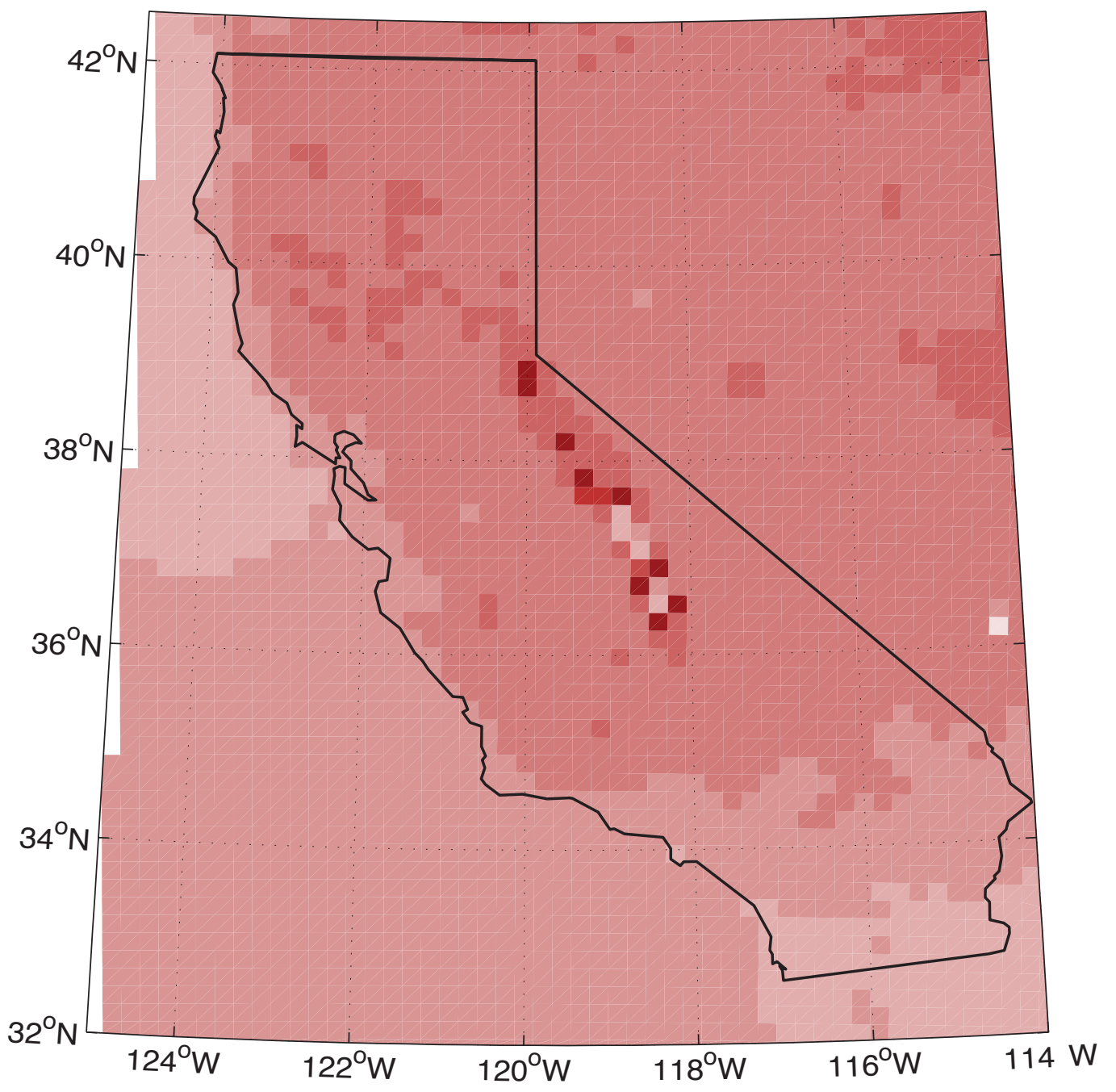




\section{(e) $4 \mathrm{PM} \mathrm{T}_{2}$, JJA}

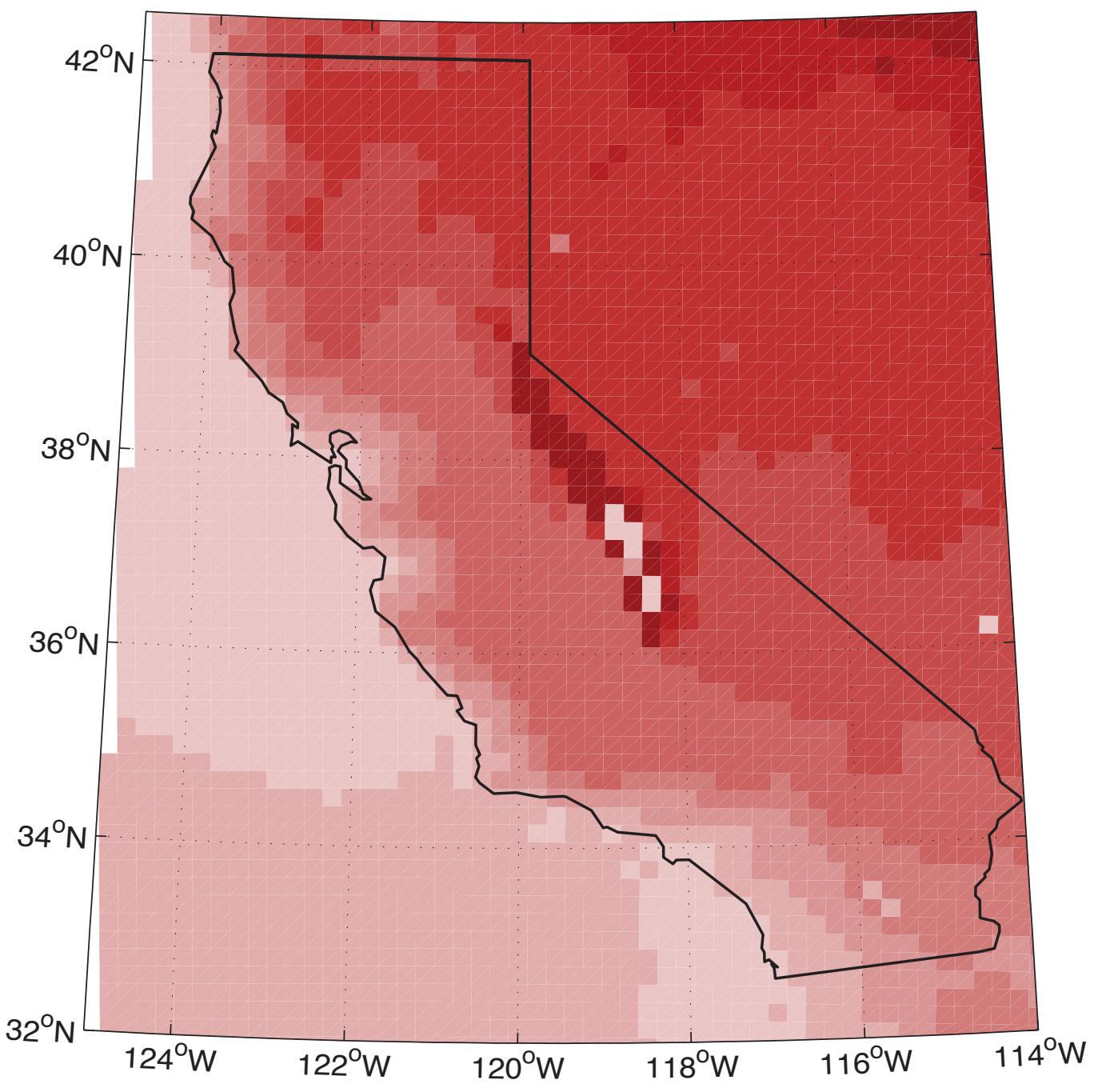




\section{(f) $4 \mathrm{PM} \mathrm{T}_{\text {veg }}$, JJA}

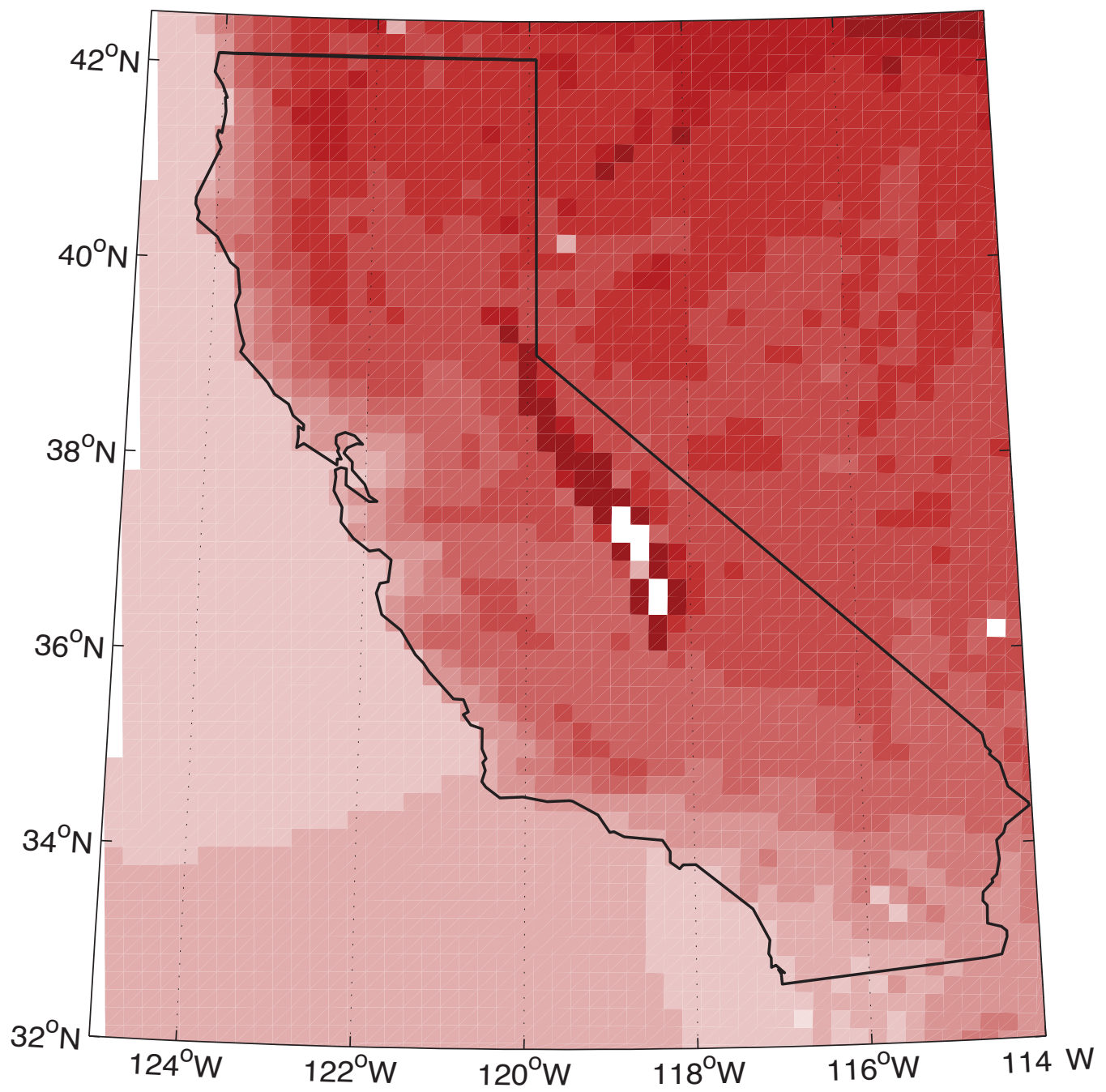




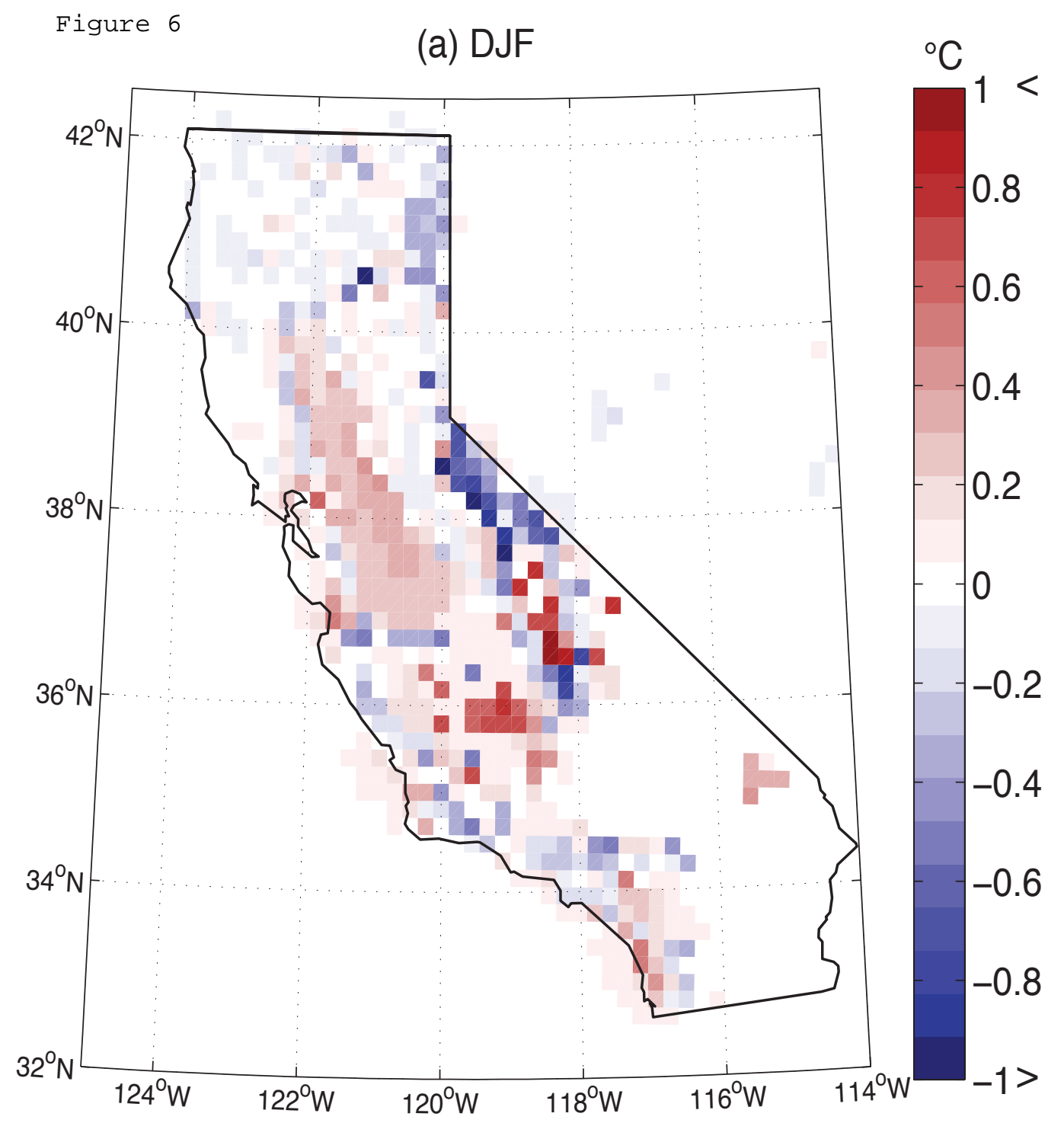


(b) MAM

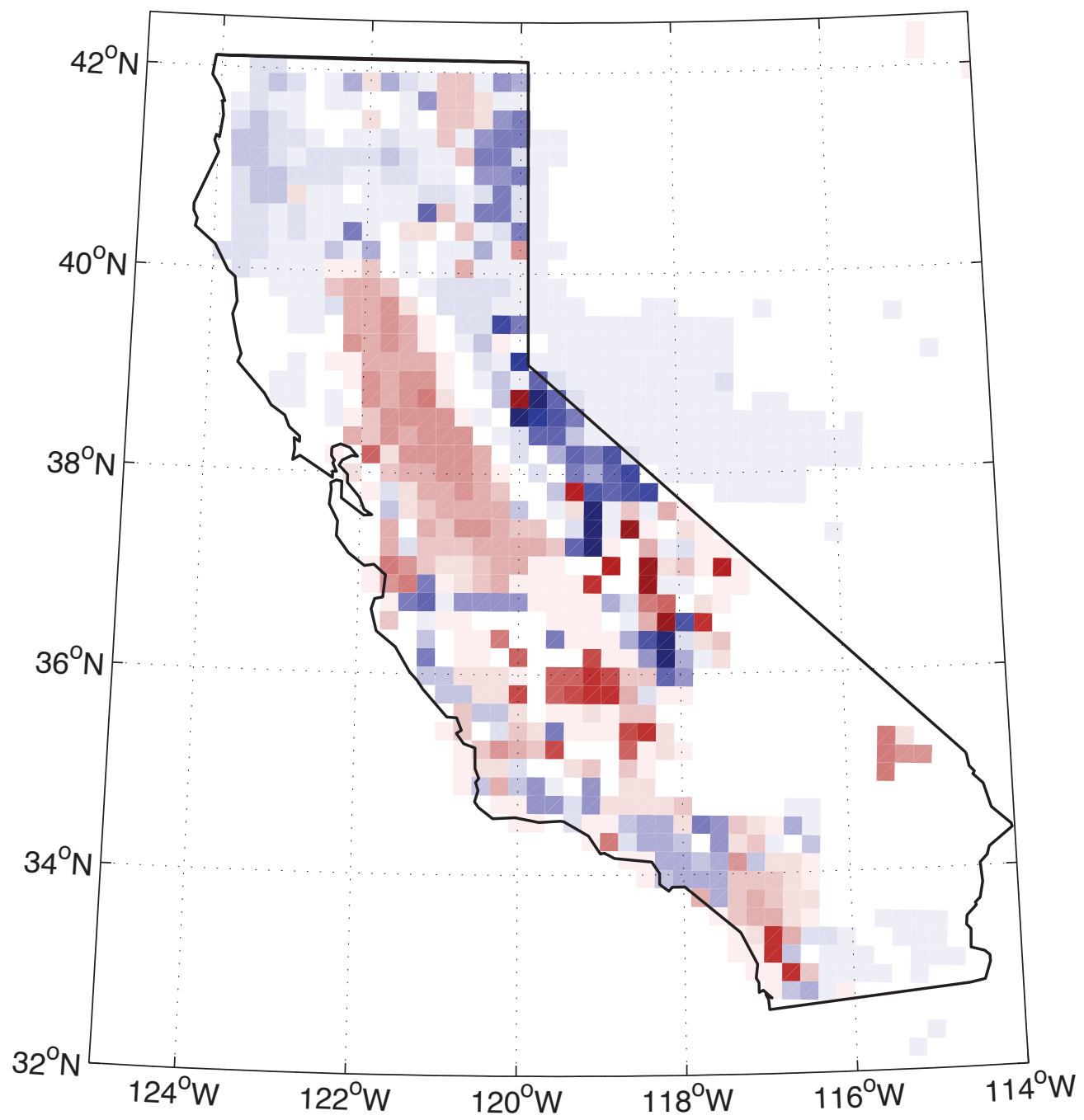


(c) JJA

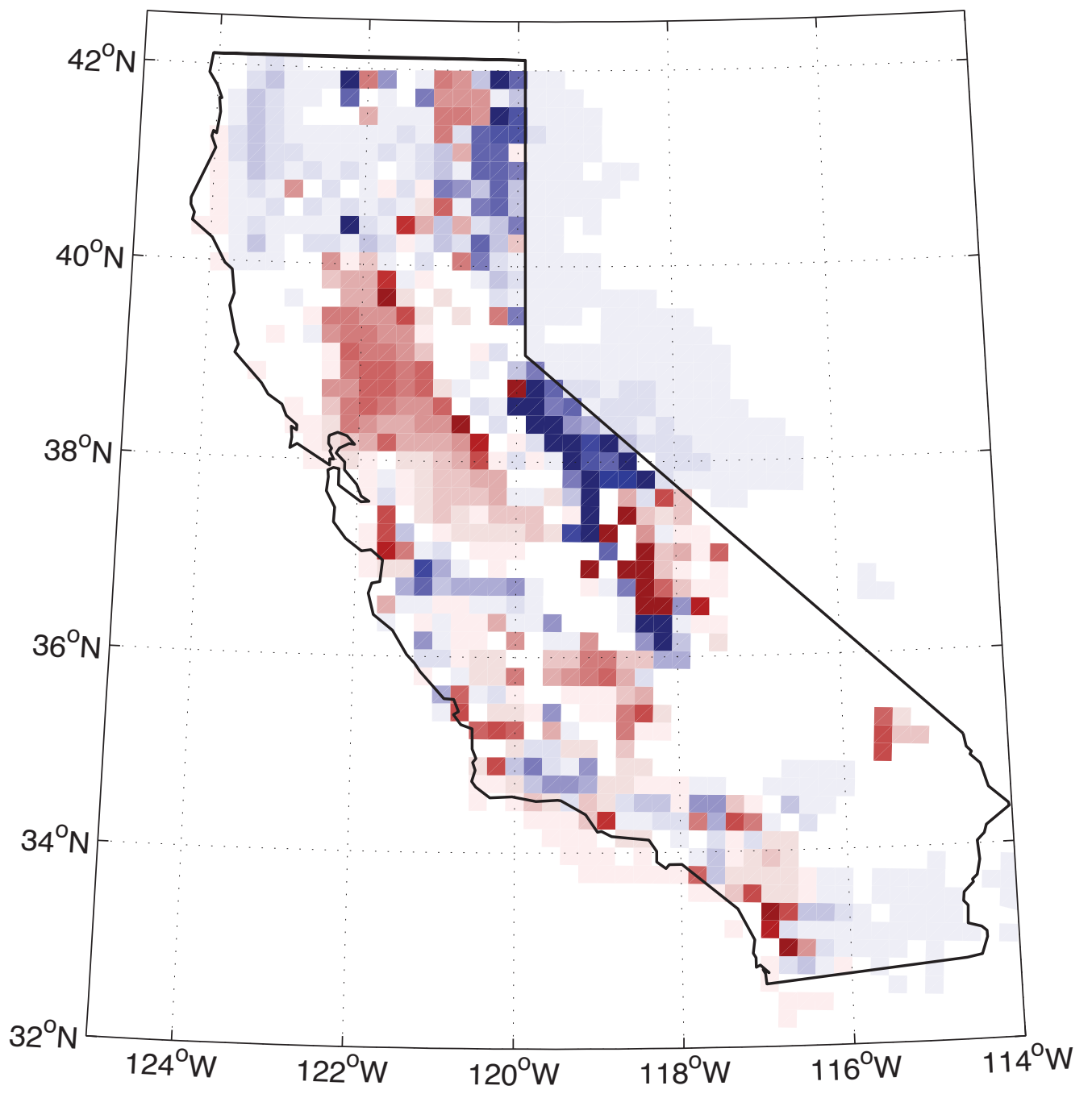




\section{(d) SON}

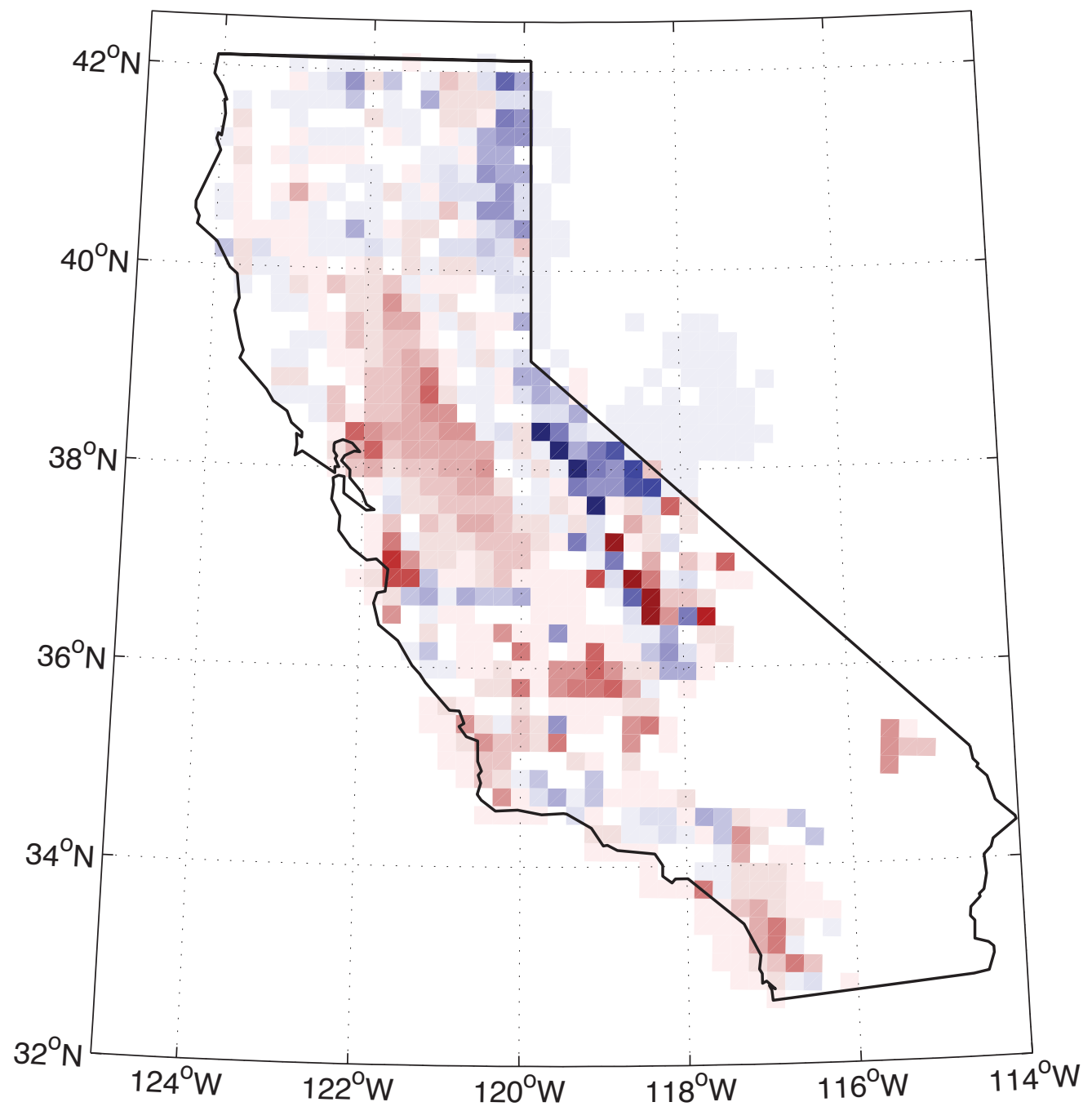


(b) $4 \mathrm{PM} \mathrm{T}_{2}$, JJA

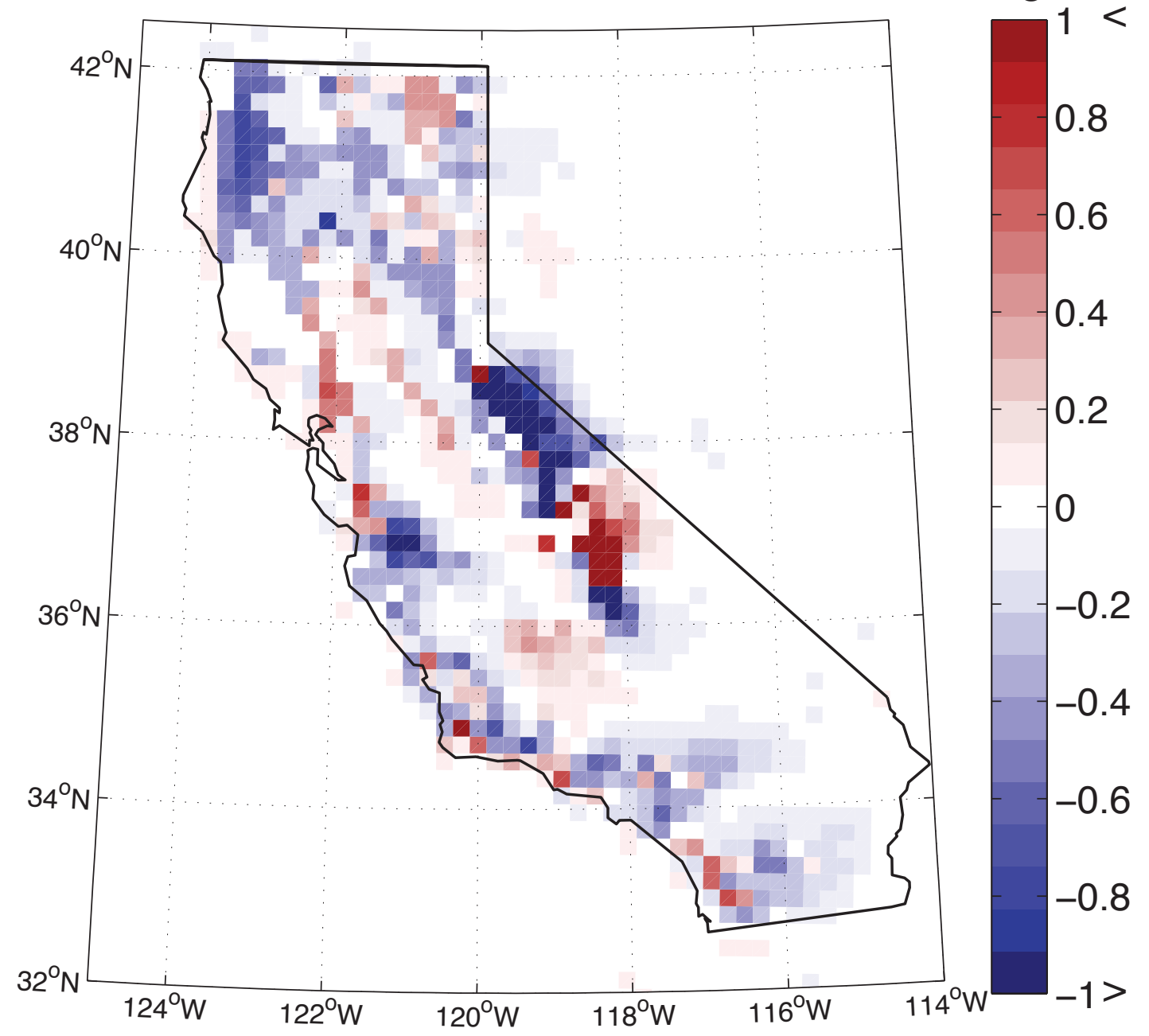


(d) 4 PM Albedo, JJA

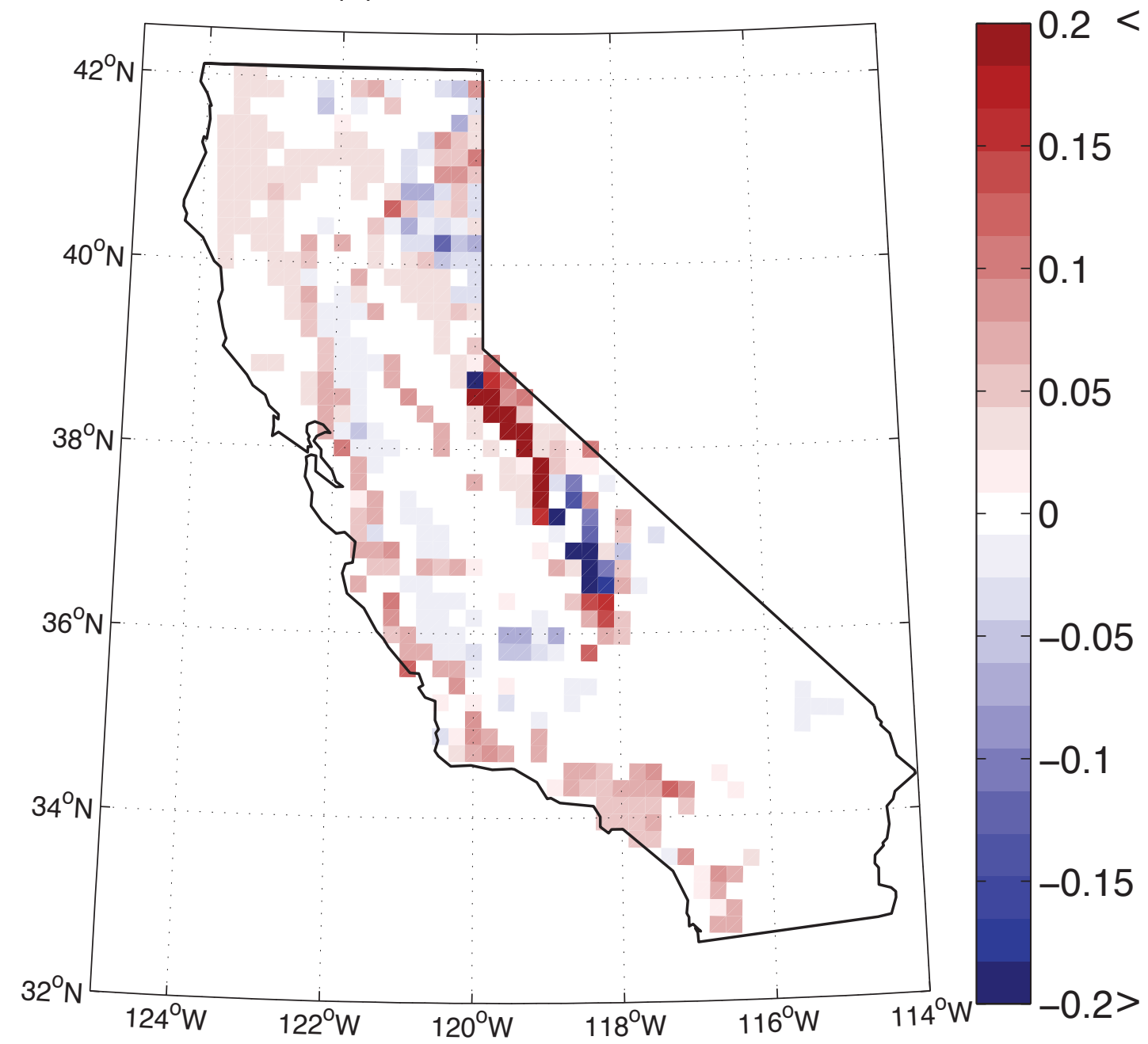


(e) 4 PM SH, JJA

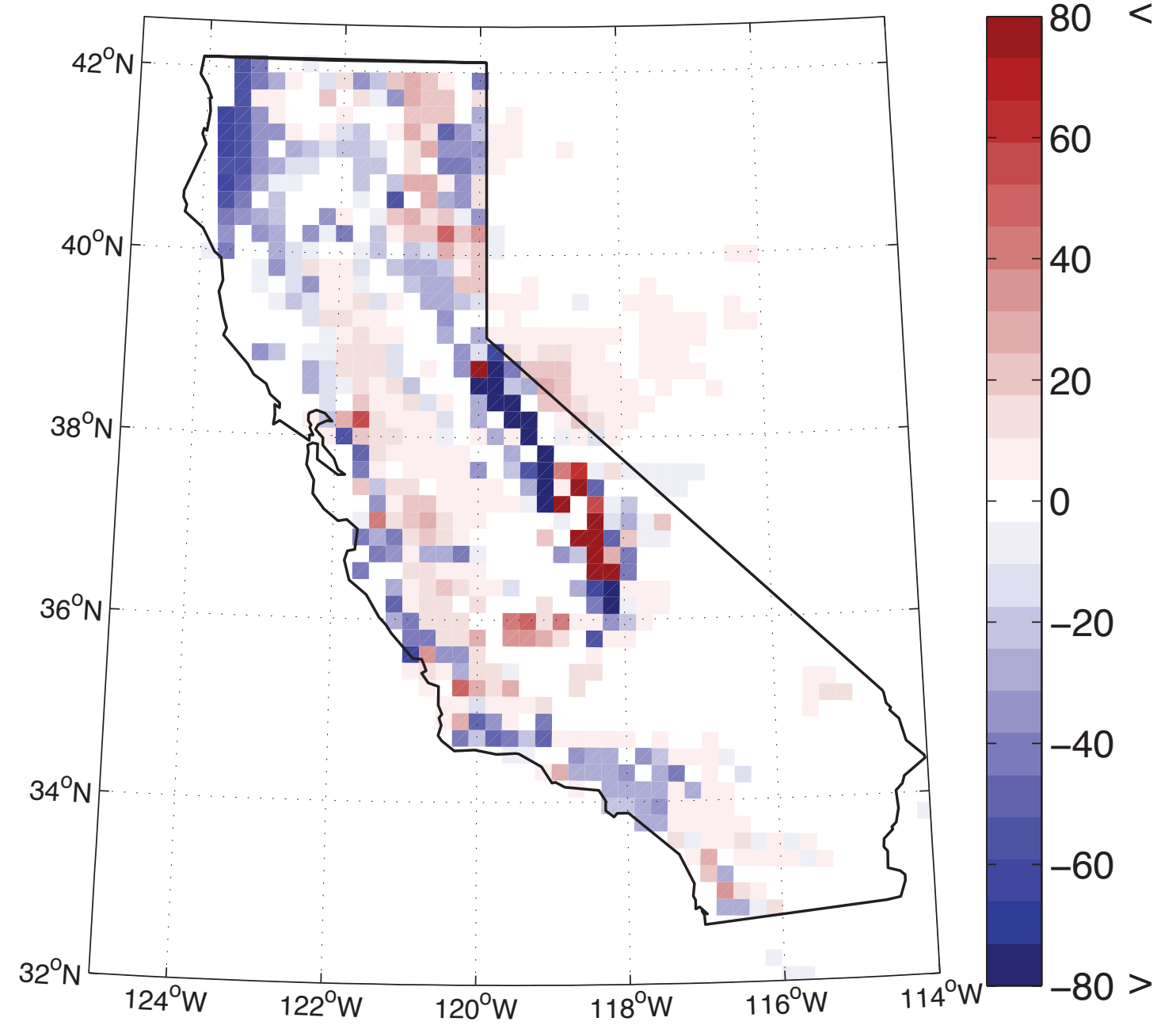


(f) 4 PM LH, JJA

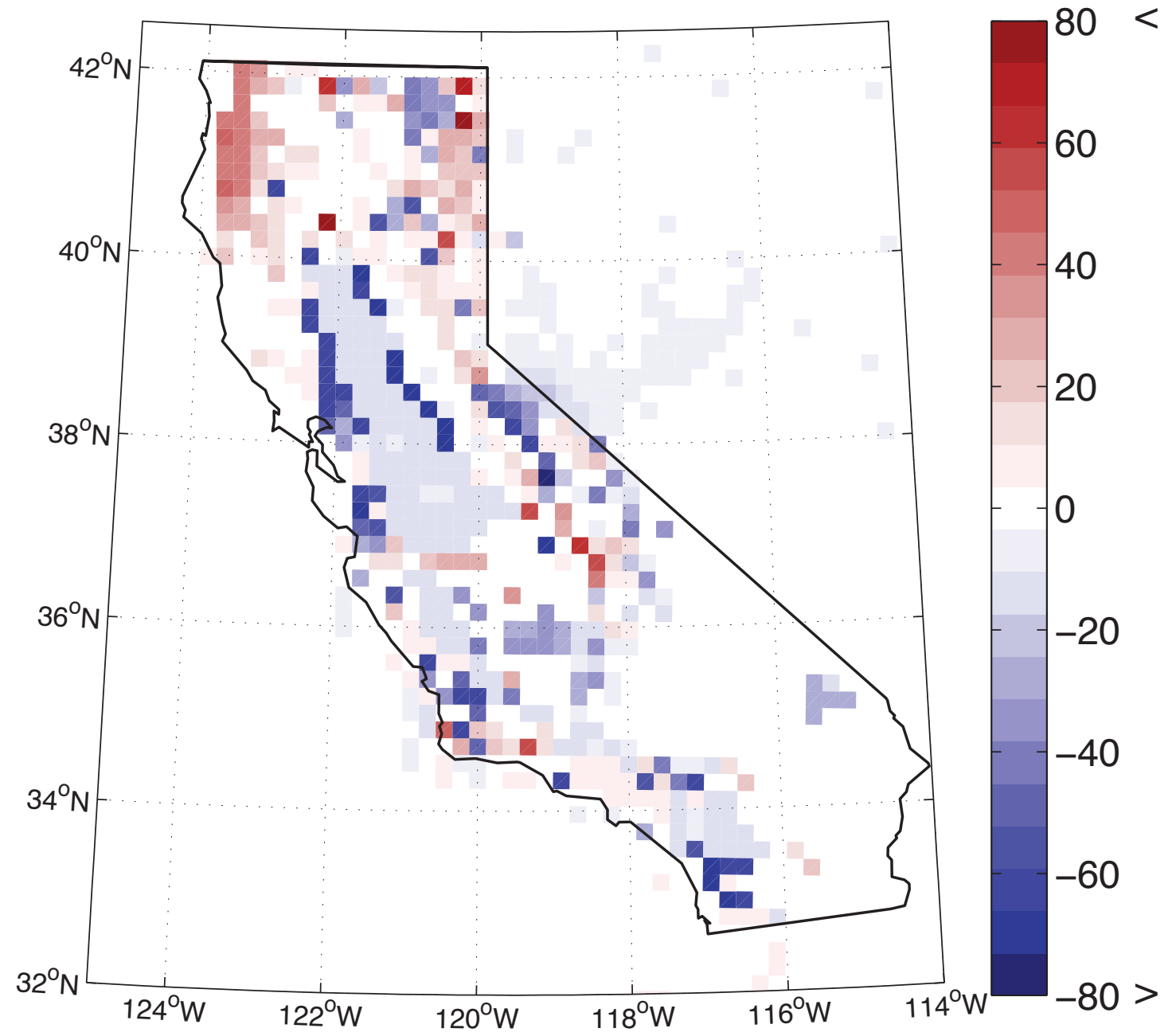




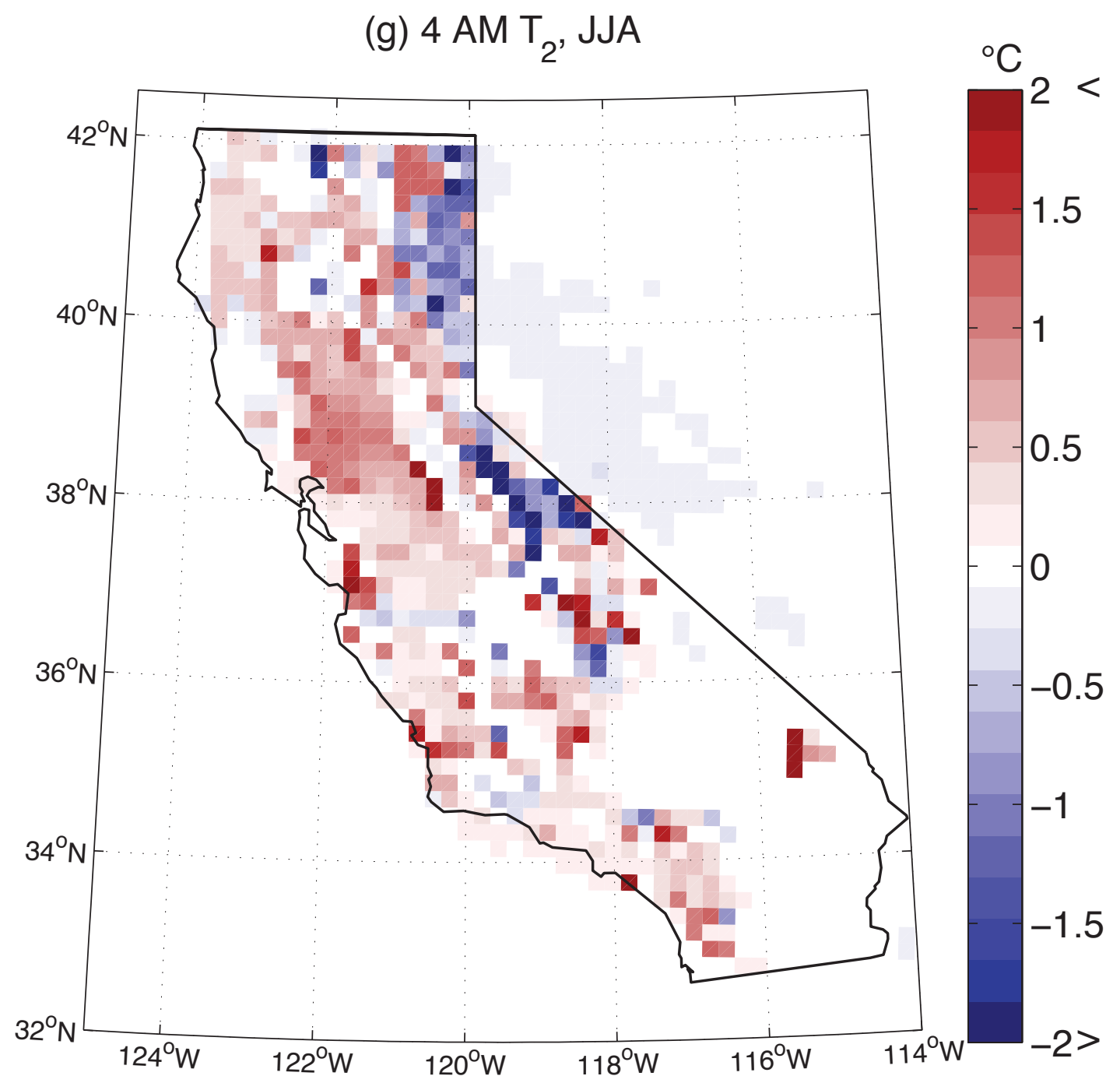


Figure 8

(a) Ann. T, FCHV-HCHV

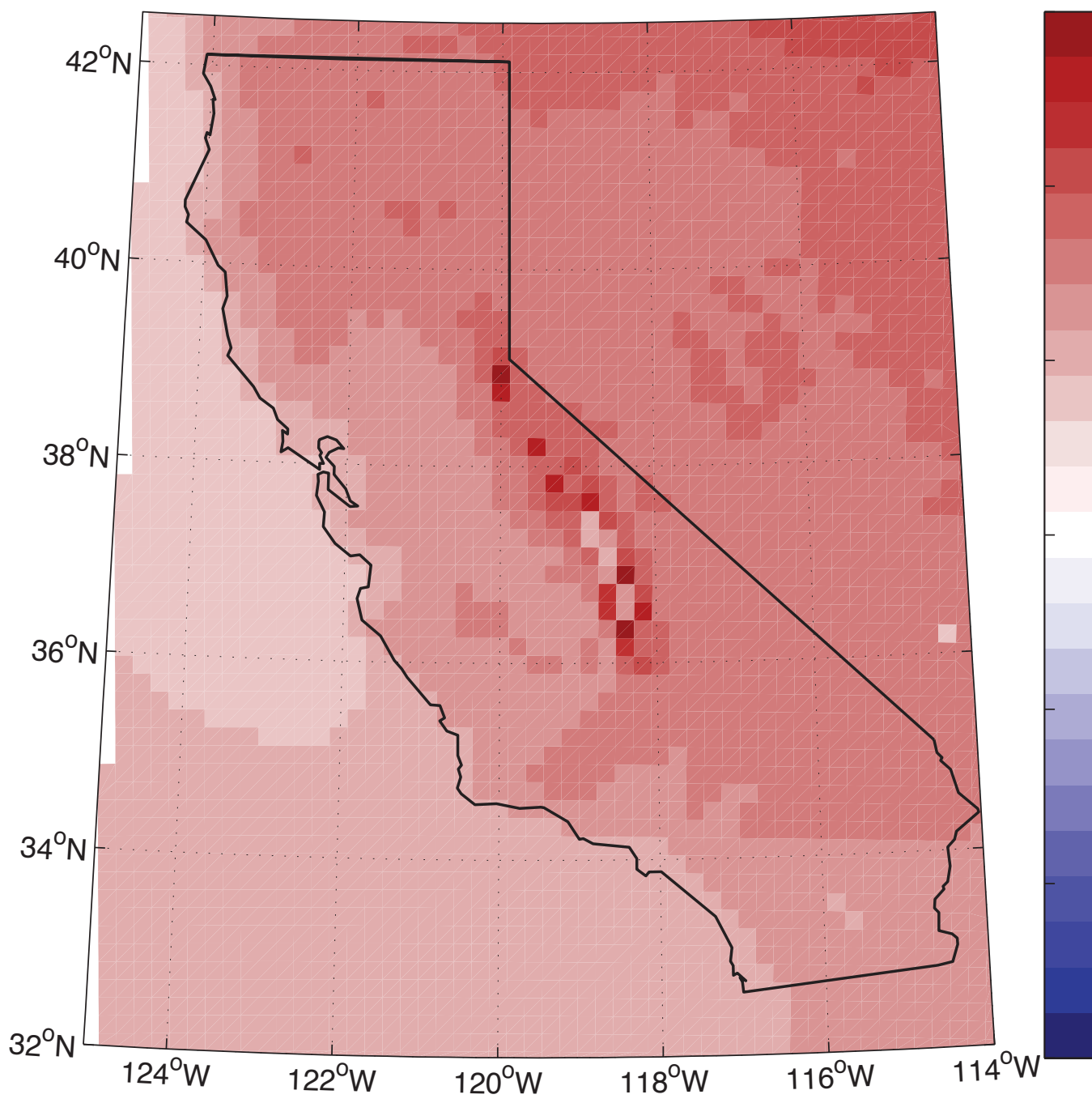




\section{(b) Ann. $\mathrm{T}_{2}$, FCFV-HCHV}

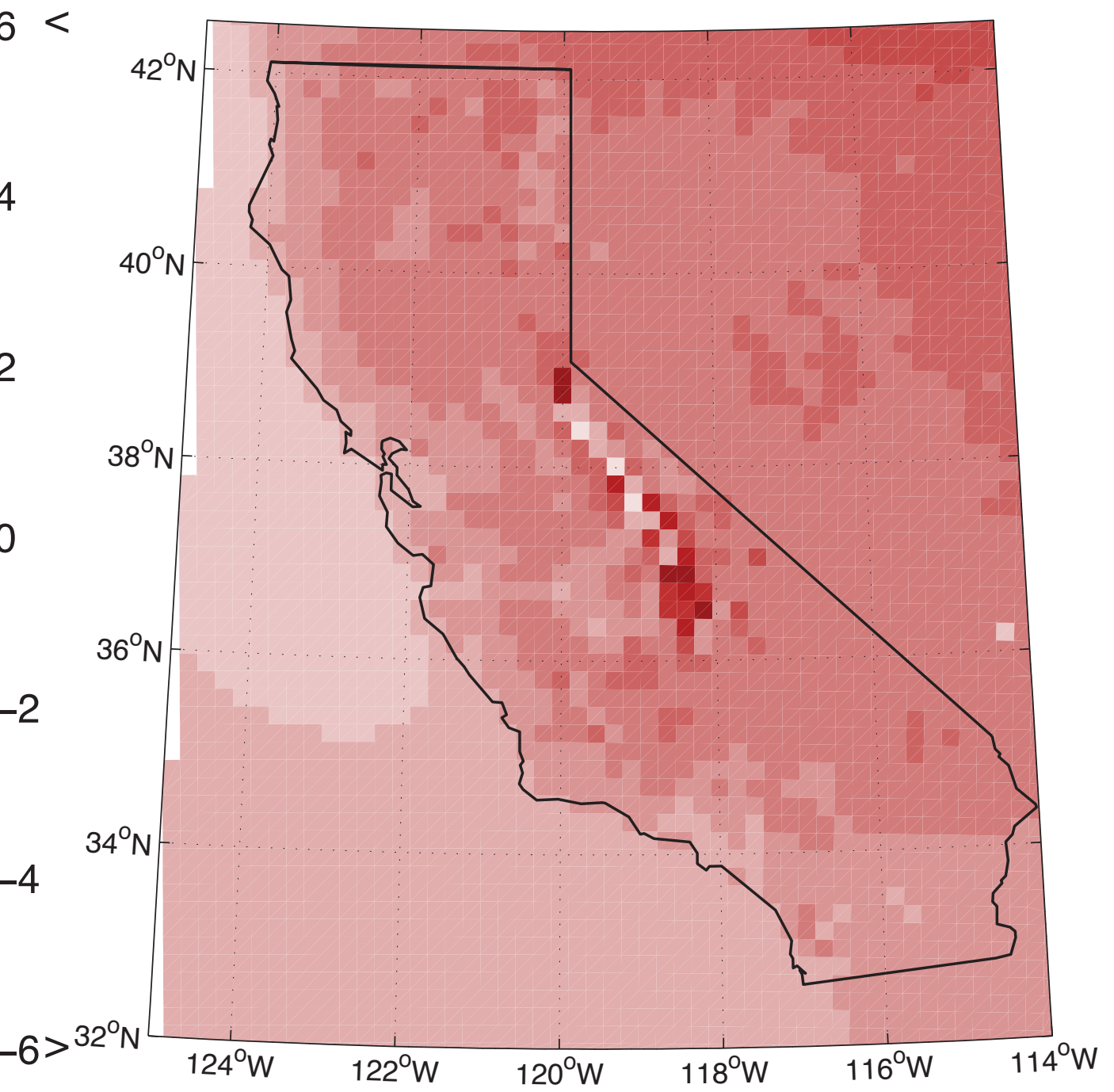


Figure 9

(a) Ann. $T_{2}$ Feedback Ratio

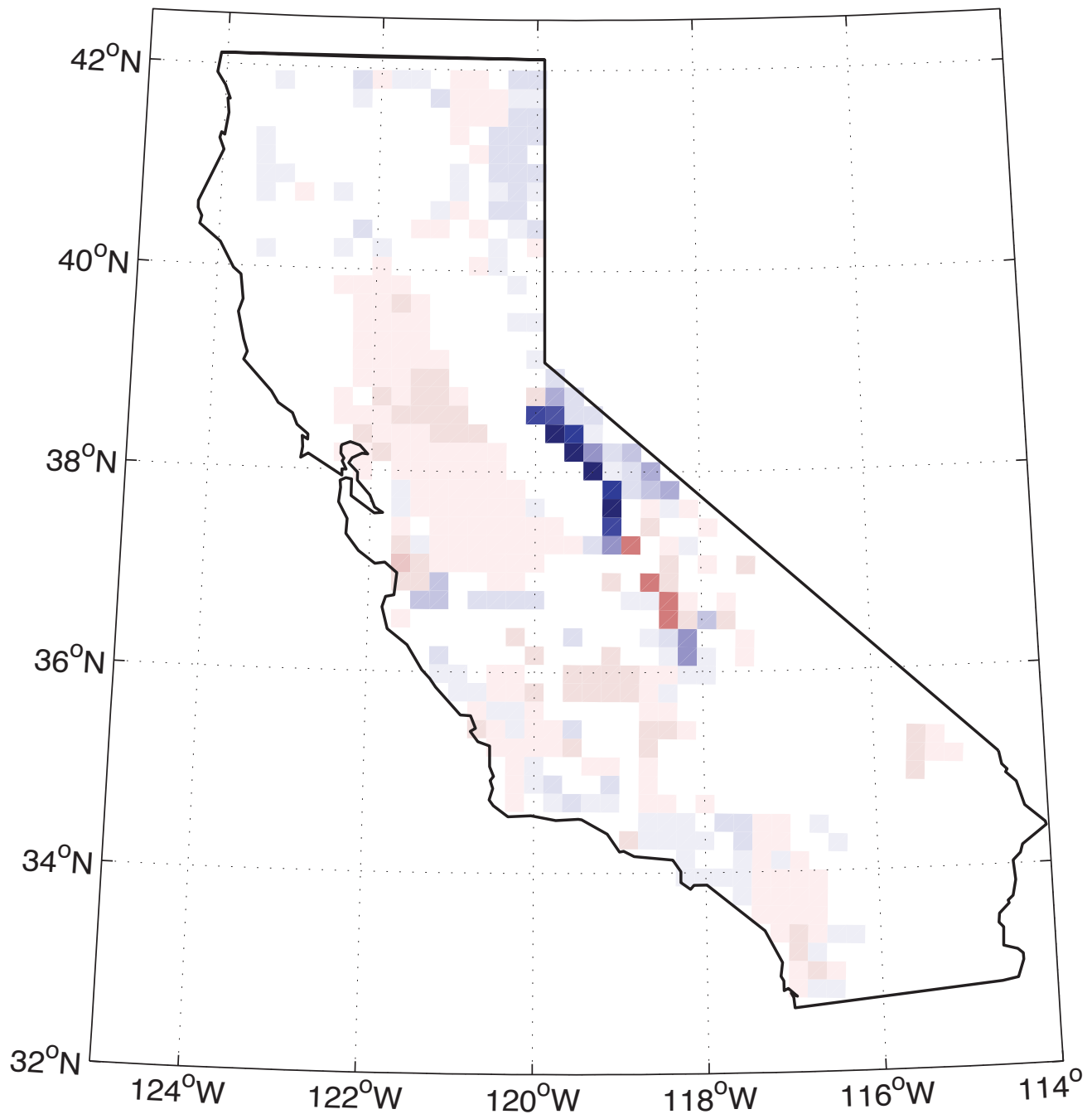




\section{(b) JJA $\mathrm{T}_{2}$ Feedback Ratio}

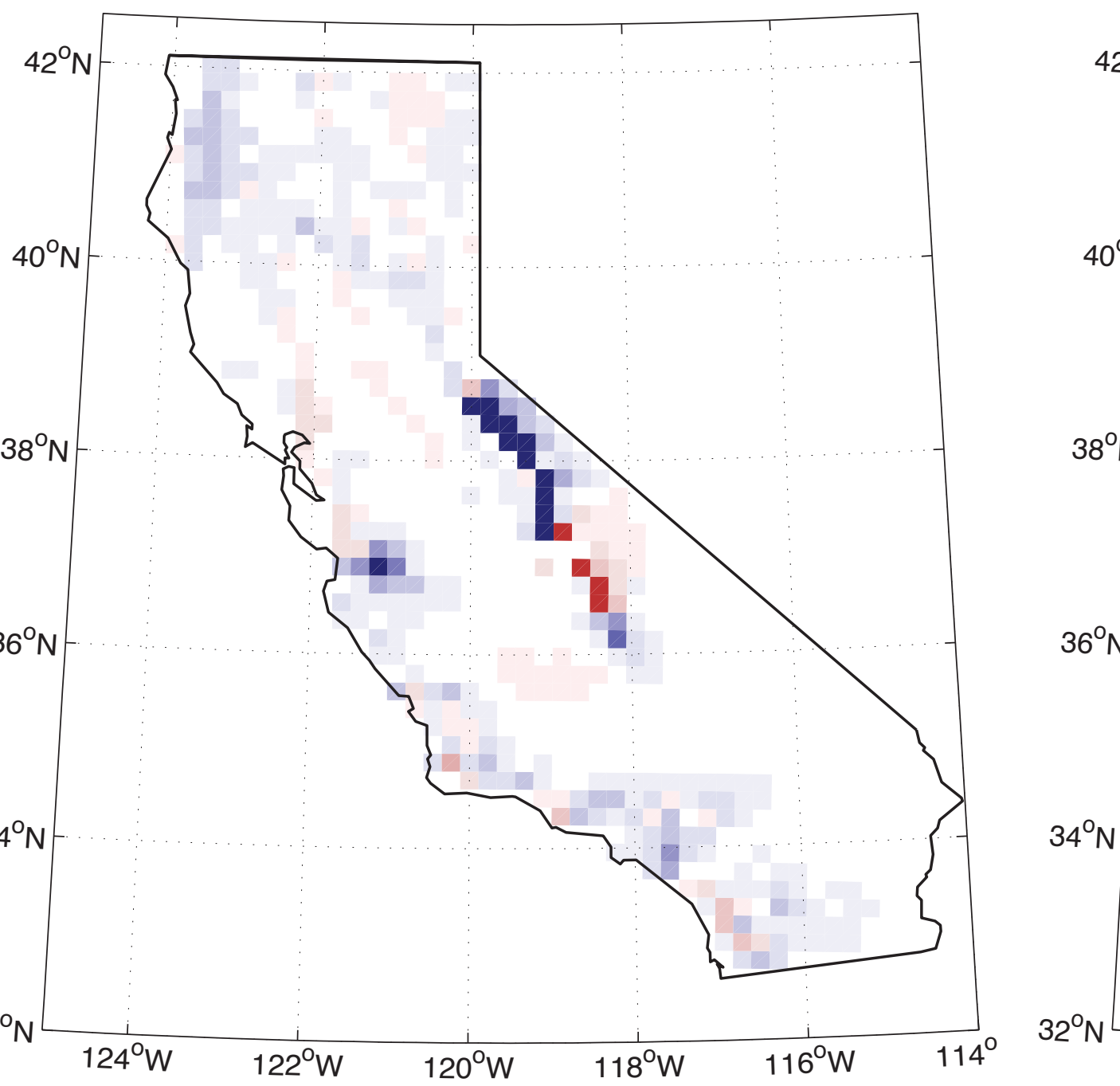




\section{(c) JJA 4 PM T veg ${ }_{\text {Feedback Ratio }}$}

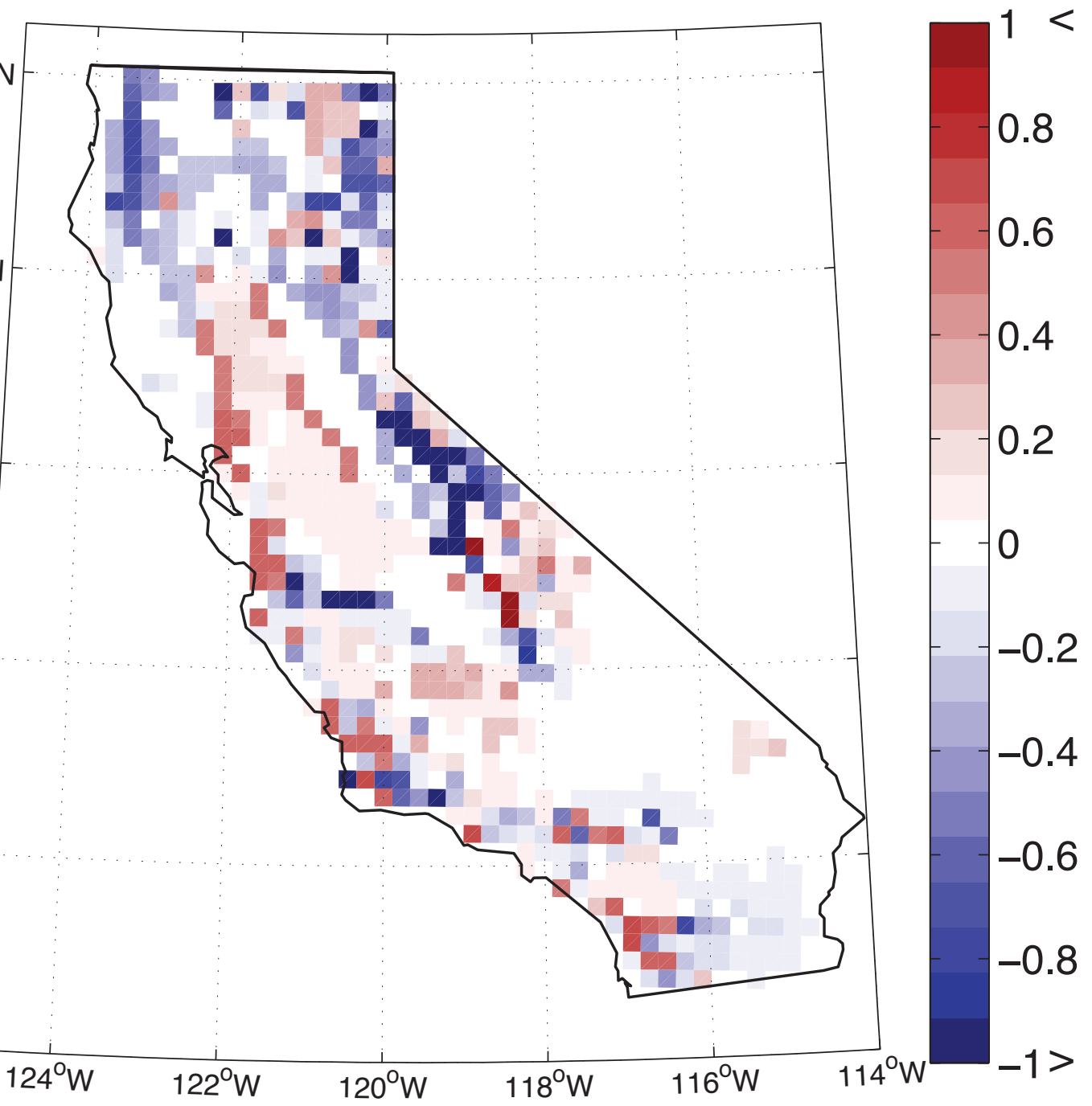




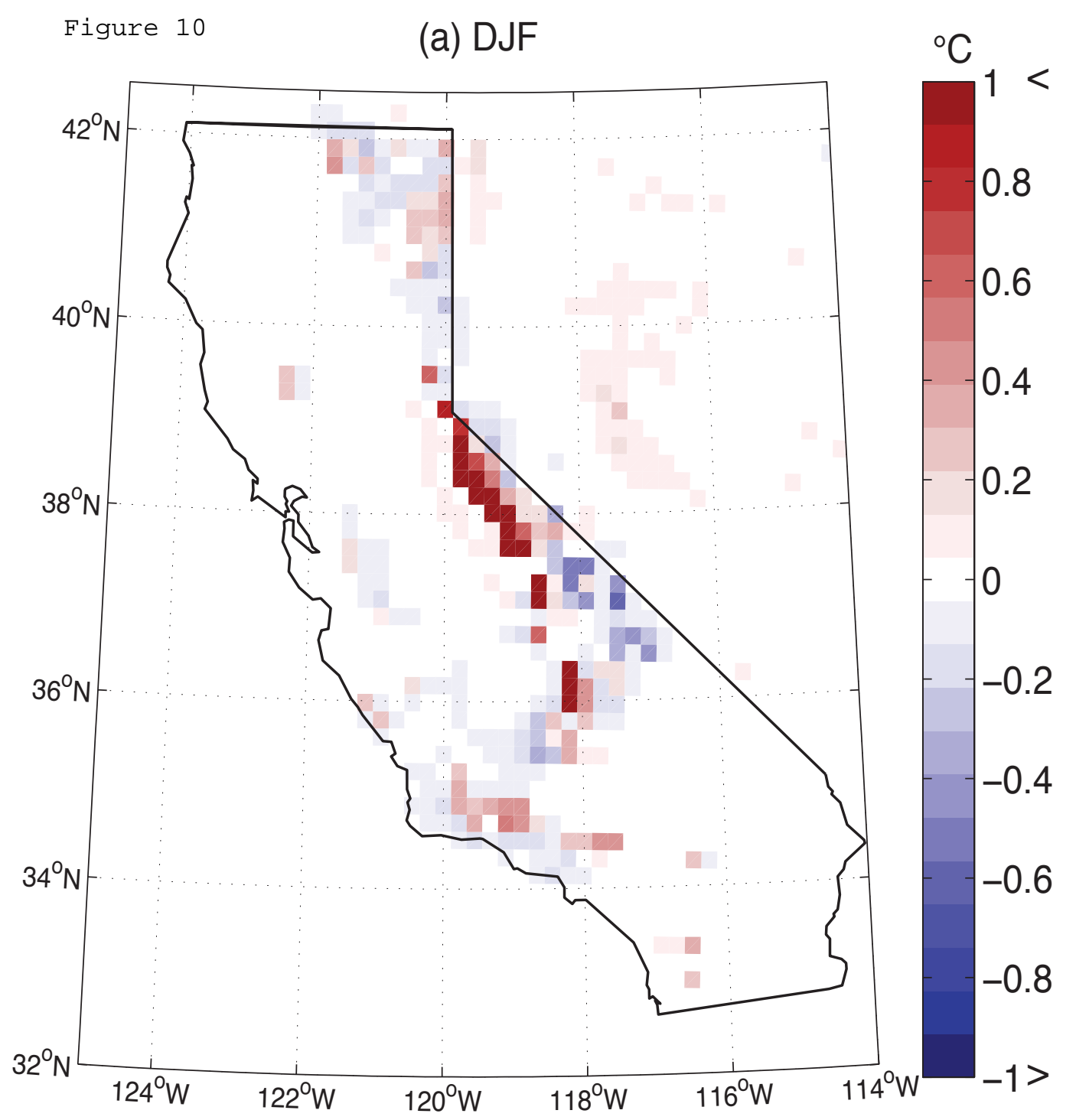




\section{(b) MAM}

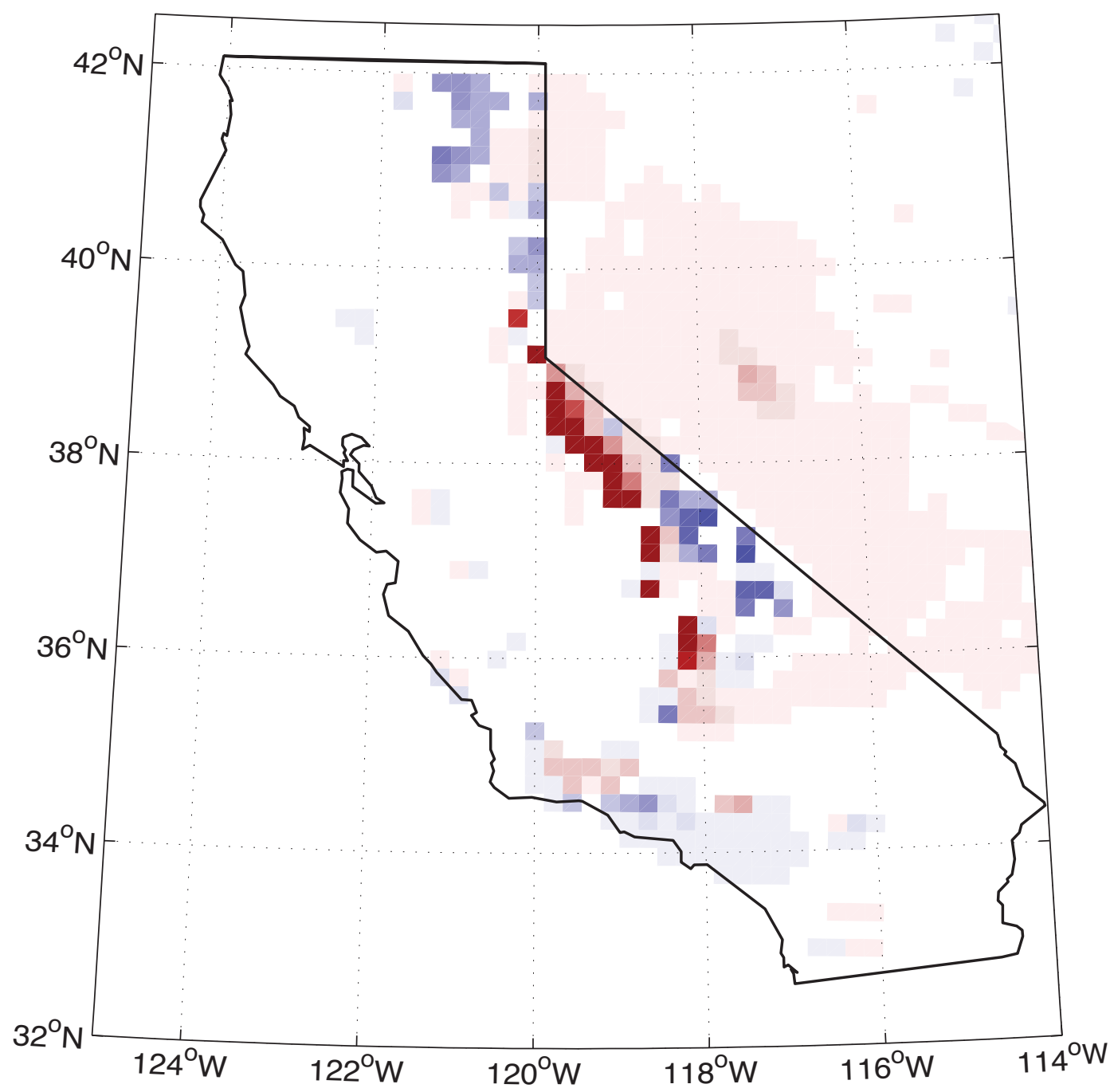


(c) JJA

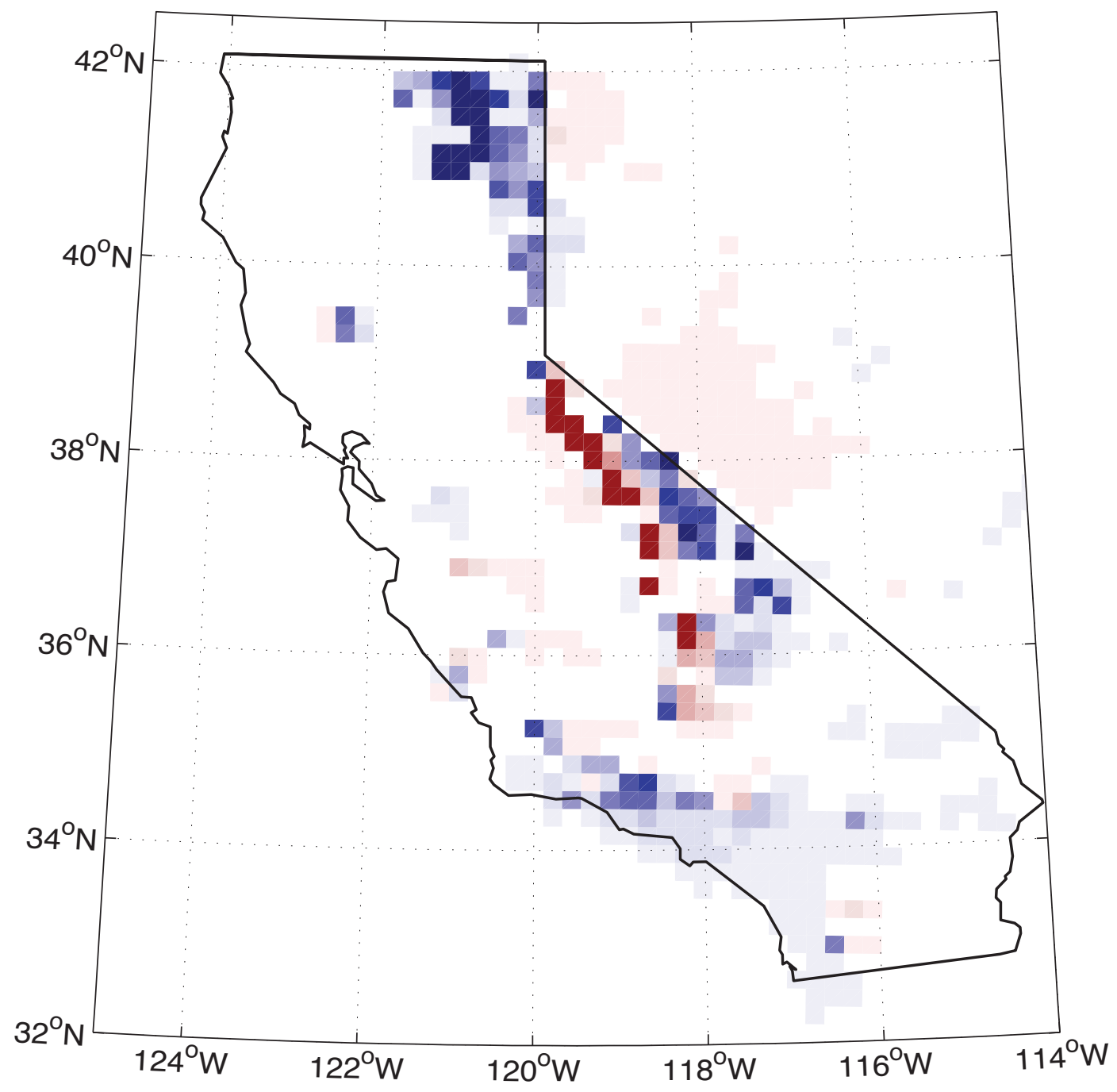


Figure 11

(a) Ann. $T_{2}$

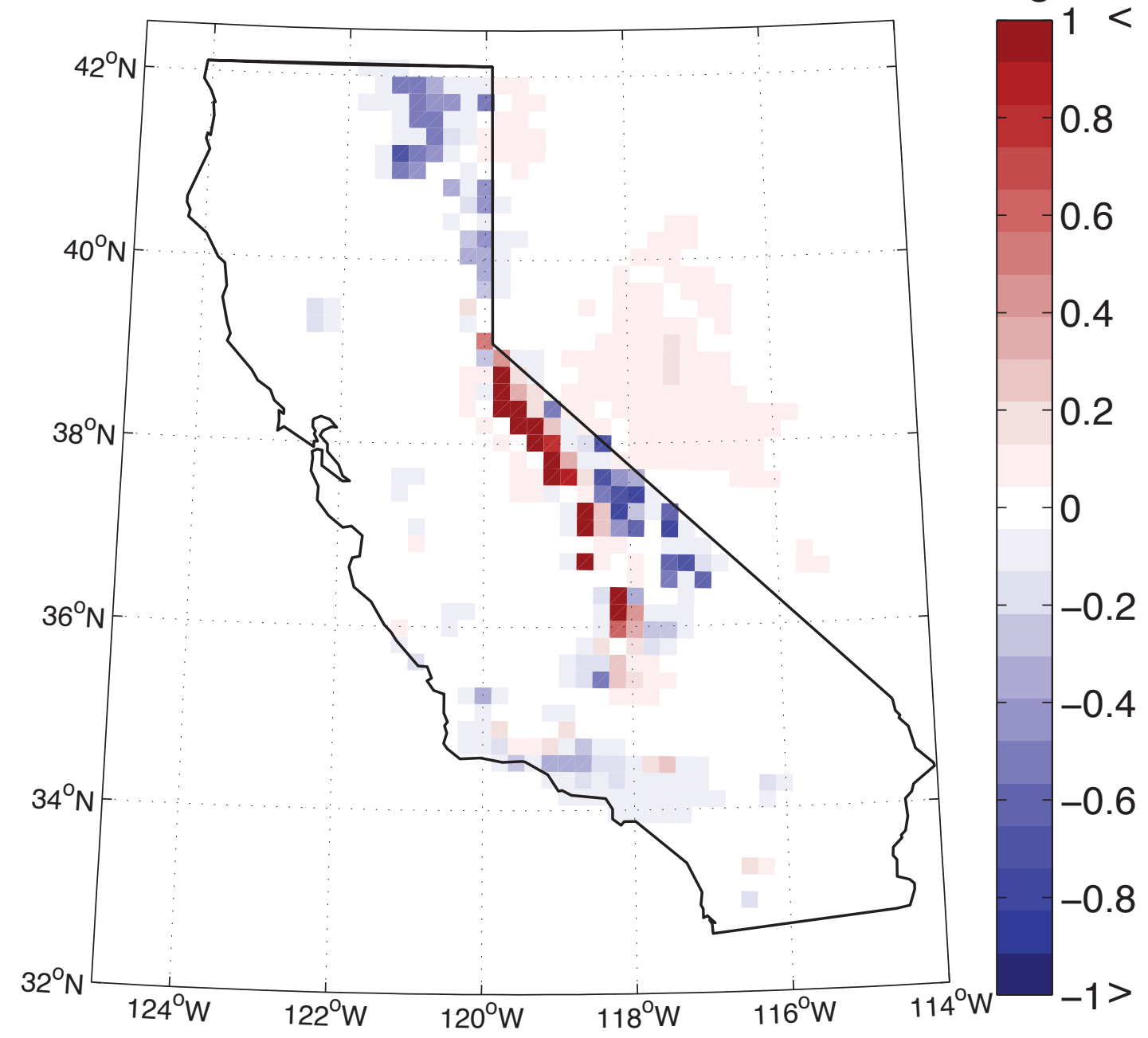


(b) $4 \mathrm{PM} \mathrm{T}_{2}$, JJA

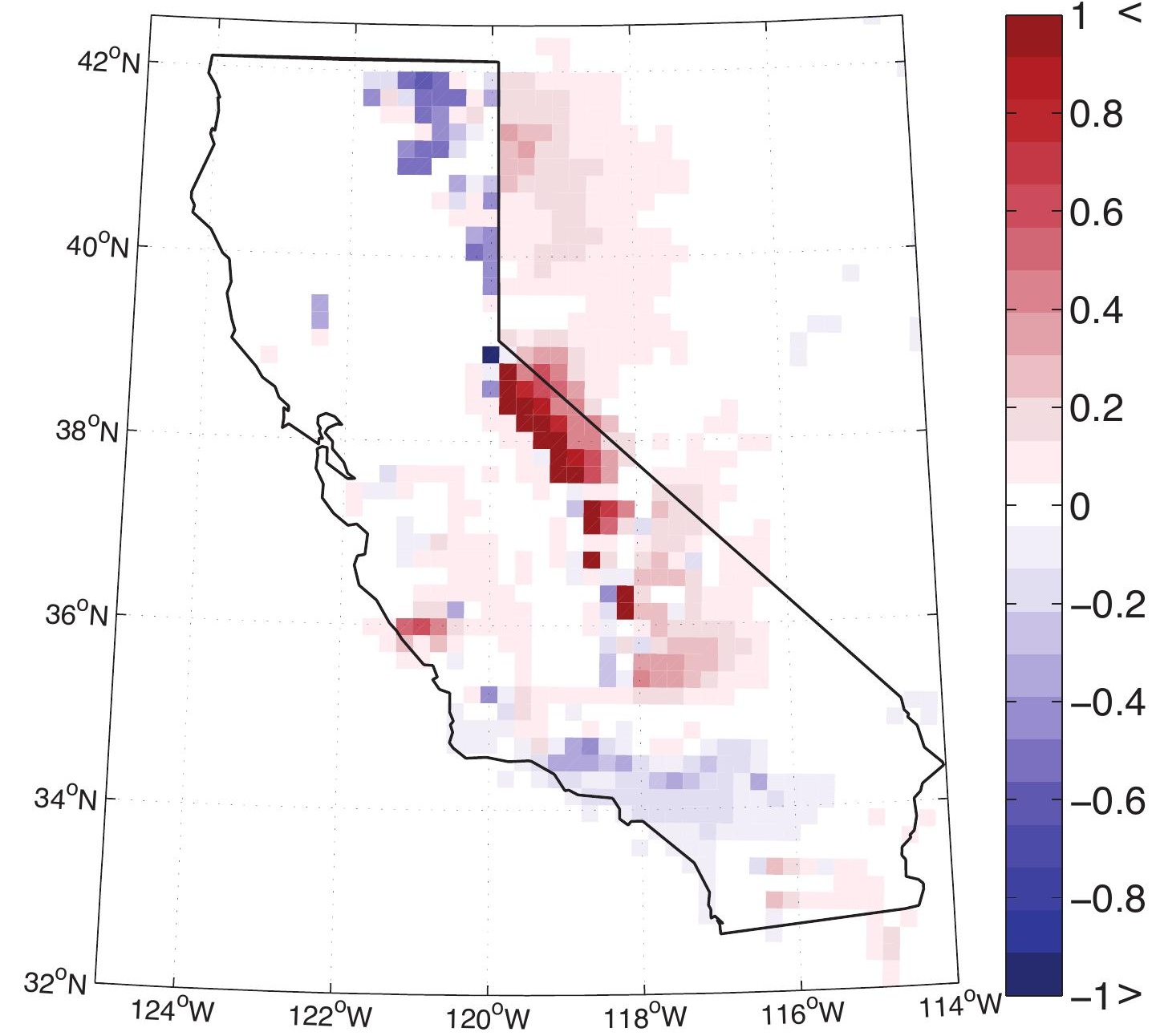


(c) $4 \mathrm{PM} \mathrm{T}_{\text {veg }}$, JJA

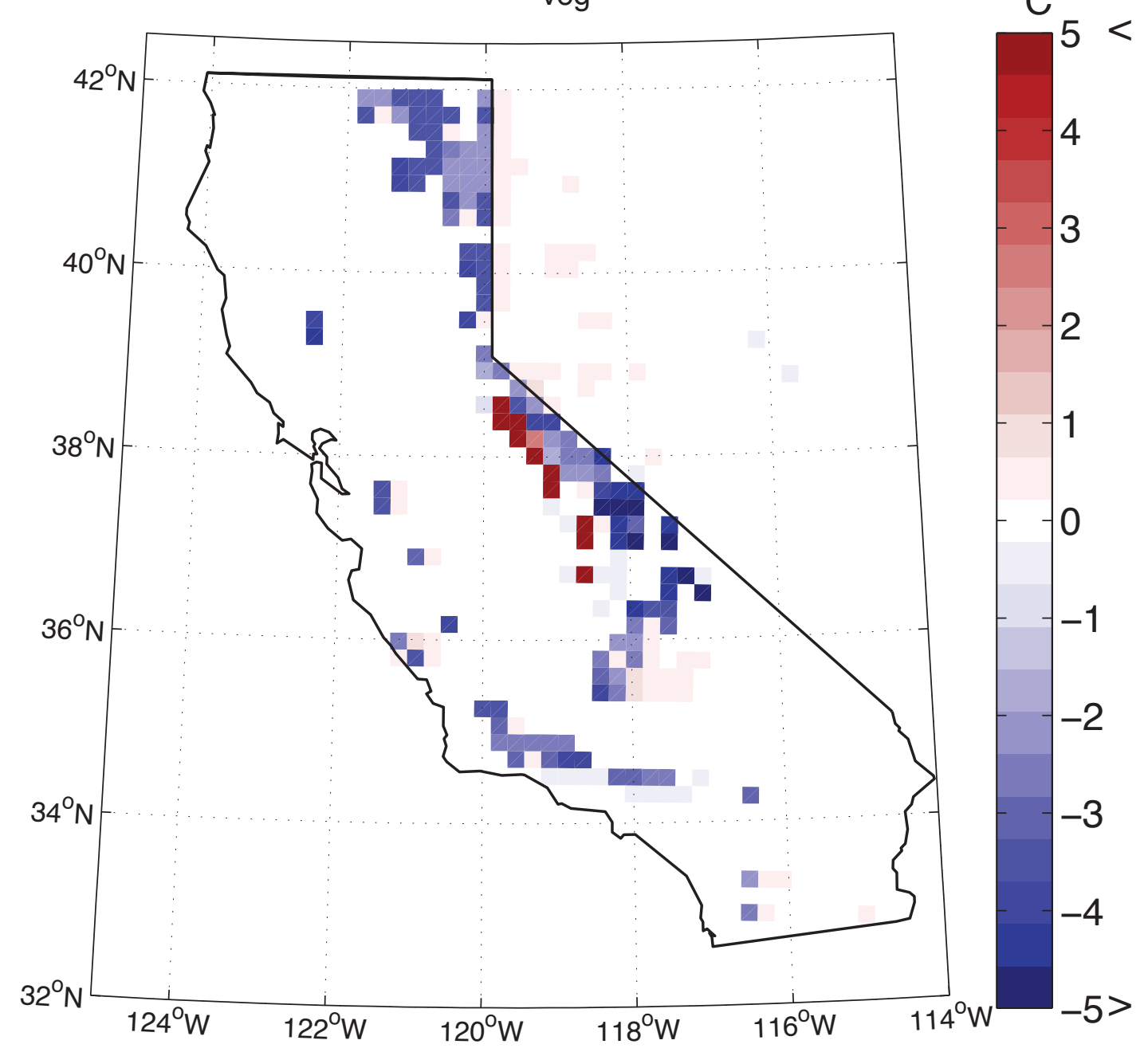


(d) 4 PM Albedo, JJA

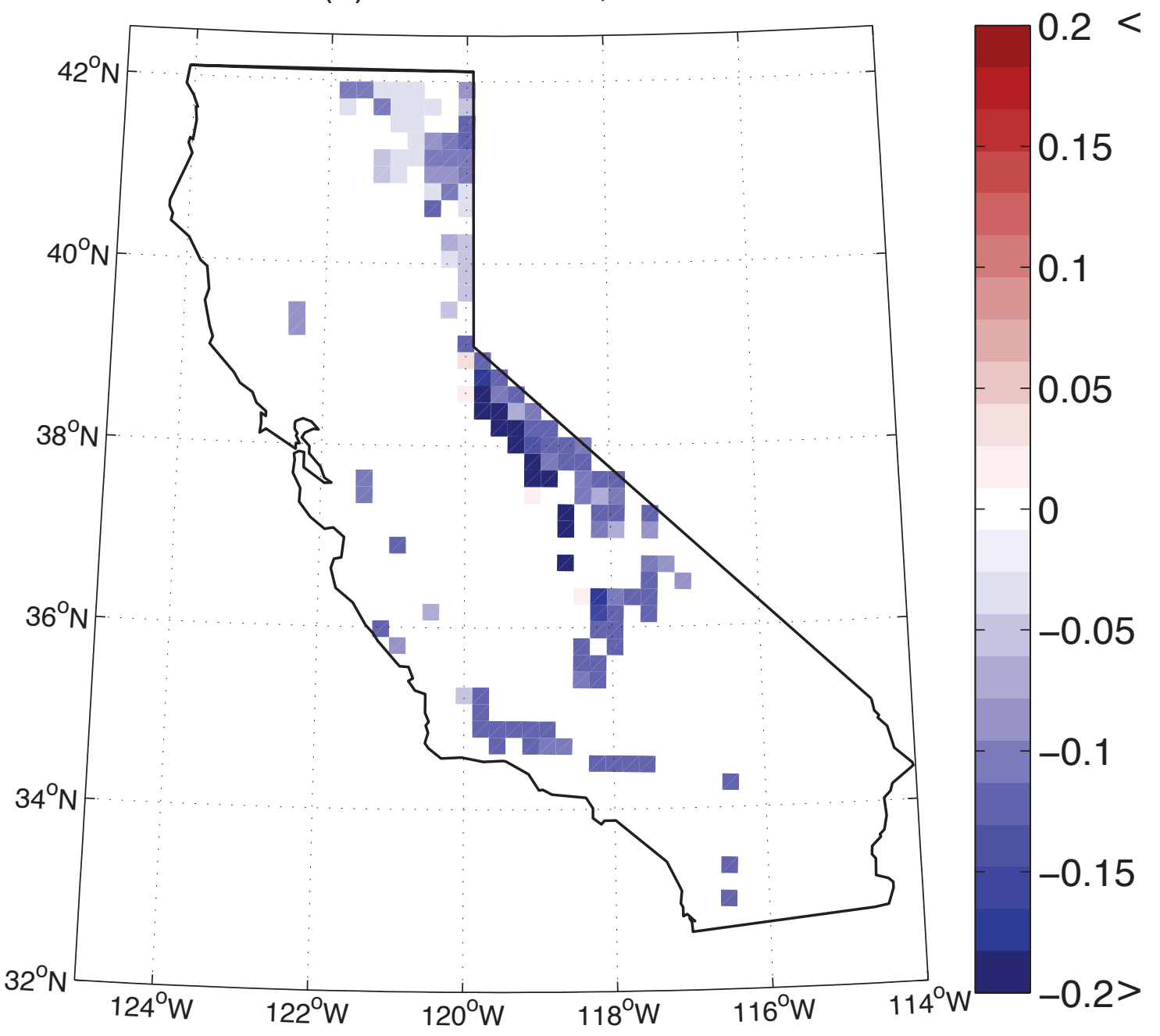


(e) 4 PM SH, JJA

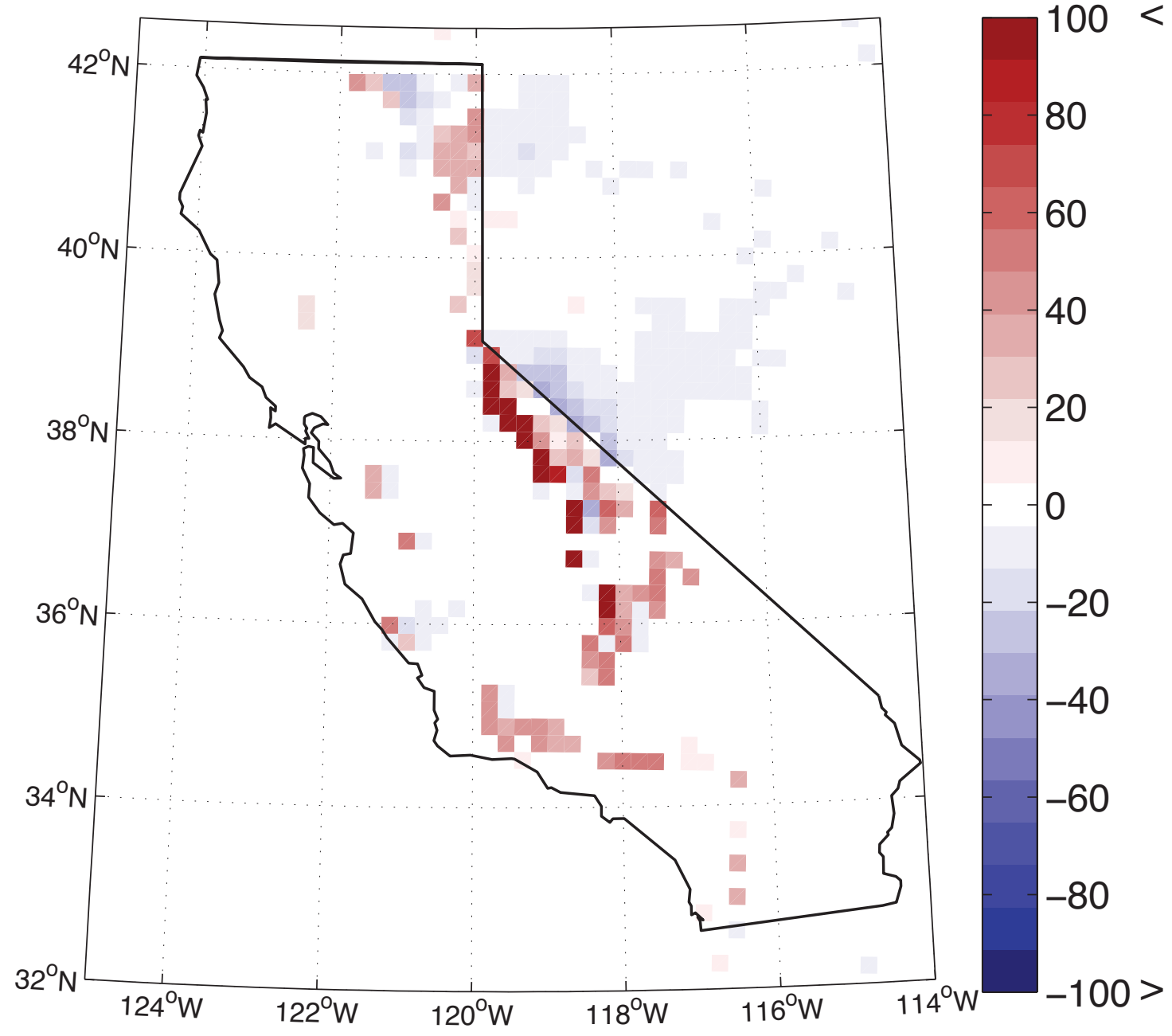


(f) 4 PM LH, JJA

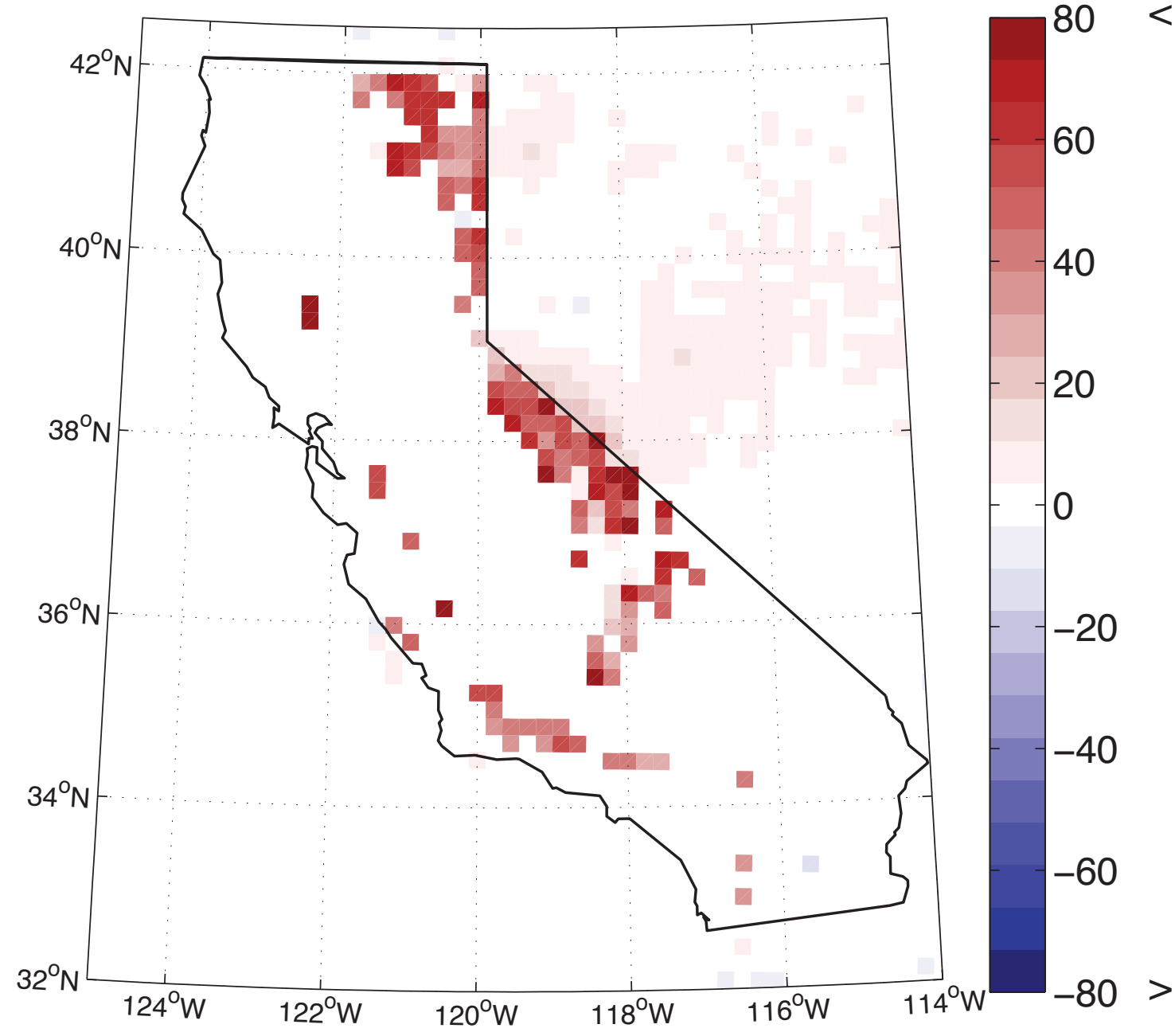




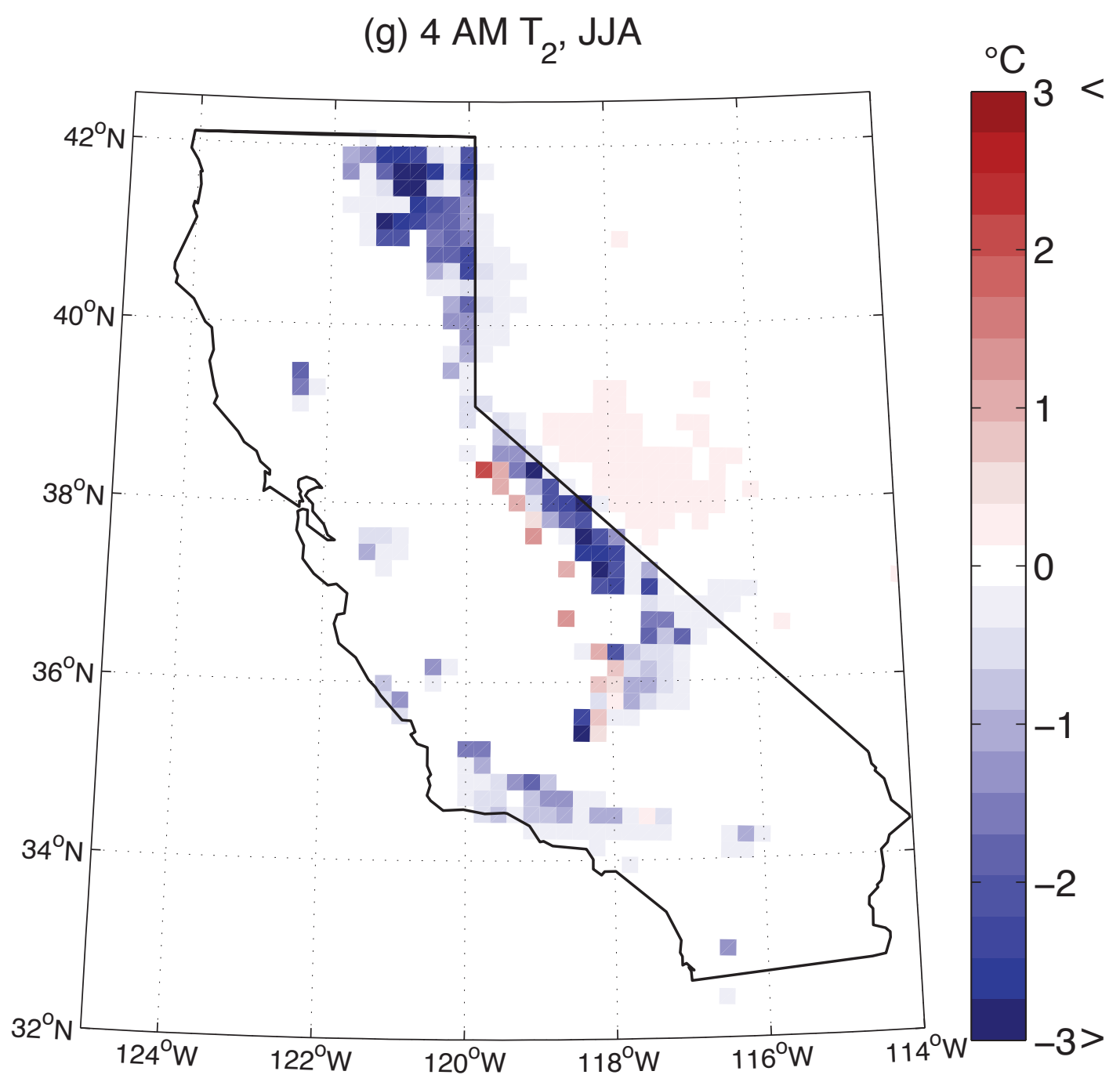




\section{(d) SON}

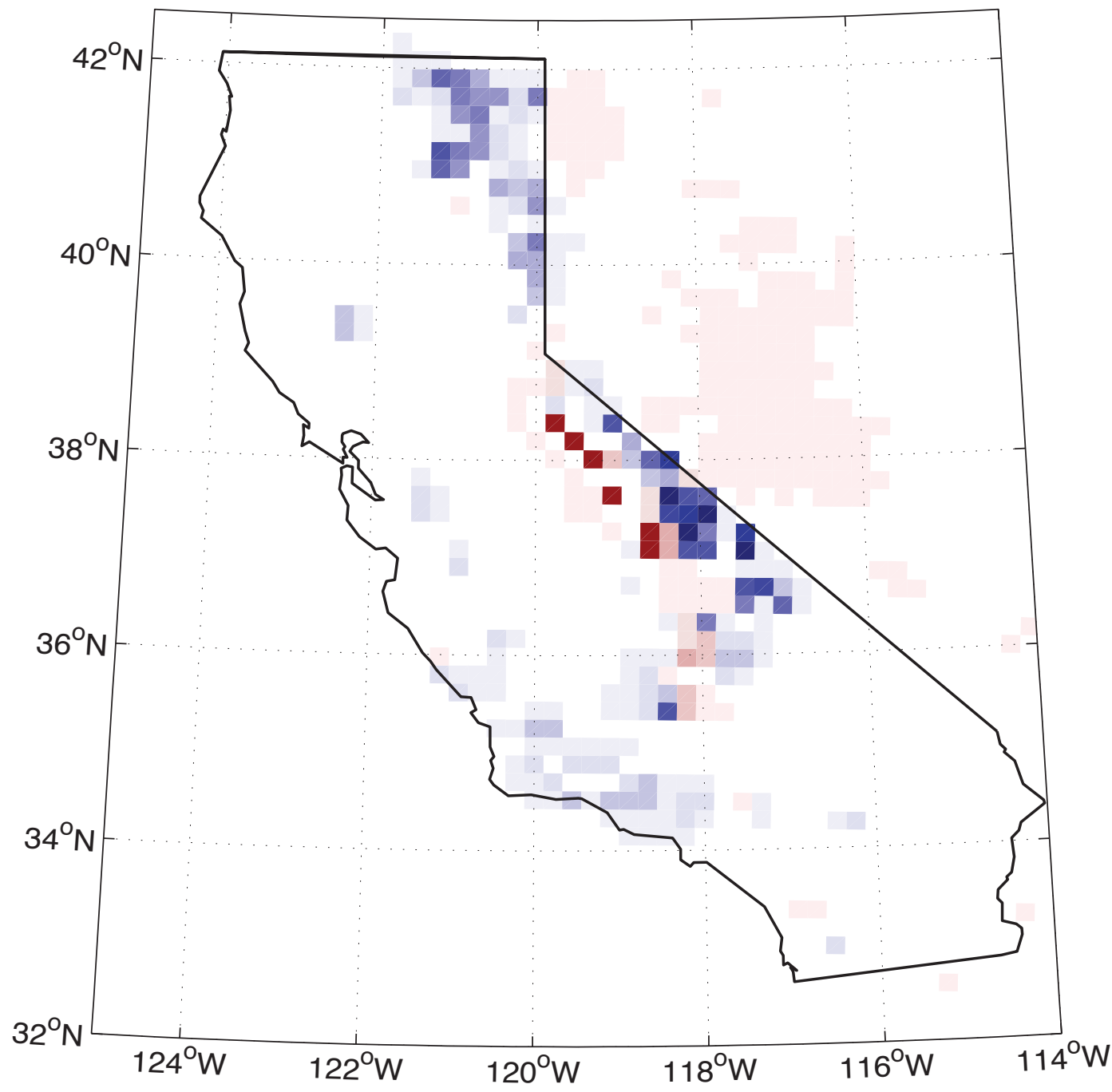


Table 1: Climate and vegetation scenario combinations used in the six simulations performed.

\section{Vegetation cases}

\begin{tabular}{lccc} 
Climate cases & $\begin{array}{c}\text { Historic } \\
\text { Native }\end{array}$ & $\begin{array}{l}\text { Future } \\
\text { Native }\end{array}$ & $\begin{array}{c}\text { Native }+ \\
\text { Afforestation }\end{array}$ \\
GFDL $20^{\text {th }}$ C. & HCHV & HCFV & HCHAV \\
GFDL SRES-A2 & FCHV & FCFV & FCFAV \\
future & & & \\
\hline
\end{tabular}


Table 2: Summary statistics comparing model evaluation simulations with monthly PRISM data for gridcells over land points in California, for monthly averaged maximum $\left(\mathrm{T}_{2} \mathrm{Max}\right)$ and minimum ( $\mathrm{T}_{2} \mathrm{Min}$ ) daily $\mathbf{2} \mathrm{m}$ air temperature, monthly precipitation, and monthly averaged dewpoint $\left(T_{d}\right)$. Bold indicates where WRF3-CLM3 is superior to WRF3-Noah.

\begin{tabular}{|c|c|c|c|c|c|c|c|}
\hline Model & Variable & Correlation & $\begin{array}{c}\text { Correlation } \\
\text { (CA only) }\end{array}$ & $\begin{array}{c}\text { Bias } \\
\frac{{ }^{\circ} \mathrm{C} \text { or } \mathrm{mm}}{\underline{\left.\mathbf{y}^{-1}\right)}}\end{array}$ & $\begin{array}{l}\frac{\text { CA only }}{\text { Bias }} \\
\frac{\left({ }^{\circ} \mathrm{C} \mathrm{or}^{-1}\right.}{\left.\mathrm{mm} \mathrm{y}^{-1}\right)}\end{array}$ & $\begin{array}{c}\text { SE } \\
\text { Ratio* }\end{array}$ & $\begin{array}{l}\text { SE Ratio* } \\
\text { (CA only) }\end{array}$ \\
\hline WRF3-CLM3.5 & $\mathrm{T}_{2} \operatorname{Max}$ & 0.973 & 0.975 & +0.64 & +0.24 & 0.961 & 1.002 \\
\hline WRF3-Noah & $\mathrm{T}_{2} \operatorname{Max}$ & 0.978 & 0.974 & +0.32 & +0.15 & 0.969 & 1.014 \\
\hline WRF3-CLM3.5 & $\mathrm{T}_{2}$ Min & 0.945 & 0.943 & +4.06 & +2.87 & 0.888 & 0.917 \\
\hline WRF3-Noah & $\mathrm{T}_{2} \mathrm{Min}$ & 0.945 & 0.941 & +5.39 & +4.07 & 0.893 & 0.896 \\
\hline WRF3-CLM3.5 & Precipitation & 0.850 & 0.898 & +19 & +20 & 1.491 & 1.520 \\
\hline WRF3-Noah & Precipitation & 0.843 & 0.894 & +20 & +21 & 1.521 & 1.543 \\
\hline WRF3-CLM3.5 & $\mathrm{T}_{\mathrm{d}}$ & 0.769 & 0.767 & +0.25 & -0.92 & 0.699 & 0.779 \\
\hline WRF3-Noah & $\mathrm{T}_{\mathrm{d}}$ & 0.715 & 0.696 & -1.01 & -2.10 & 0.655 & 0.737 \\
\hline
\end{tabular}

*Standard error ratio: the square root of the variance ratio, simulation / observation. 
Table 3: Summary of surface variable changes for FCFV-FCHV (left 4 columns) and FCFAV-FCFV (right 2 columns) for the whole state of California and for Transition A (FCFV-FCHV, forest, woodland, or mixed grassland $\rightarrow \mathrm{C}_{4}$-dominated grassland in the Northern Central Valley), Transition B (FCFV-FCHV, continental temperate coniferous forest $\rightarrow$ warm temperate / subtropical mixed forest and temperate mixed xeromorphic woodland transition in the Northwest corner of the state), Transition C (FCFV-FCHV, temperate arid shrubland $\rightarrow$ mixed grassland in the Northeast corner of the state), and Transition D (FCFAV-FCFV, from any other ecosystem type to continental temperate coniferous forest in the Northeast corner of the state). Transitions are illustrated in Figure 2b-c.

\begin{tabular}{|c|c|c|c|c|c|c|}
\hline \multirow[t]{2}{*}{$\underline{\text { Variable }}$} & \multicolumn{4}{|l|}{ FV-HV: } & \multicolumn{2}{|l|}{ AV-FV: } \\
\hline & Whole State & Trans. A & Trans. B & $\underline{\text { Trans. C }}$ & Whole State & Trans. D \\
\hline Ann $\mathrm{T}_{2}\left({ }^{\circ} \mathrm{C}\right)$ & 0 & +0.3 & -0.1 & -0.5 & 0 & -0.3 \\
\hline $\mathrm{JJA} \mathrm{T}_{2}\left({ }^{\circ} \mathrm{C}\right)$ & 0 & +0.4 & -0.1 & -0.6 & 0 & -0.7 \\
\hline $\mathrm{JJA} \mathrm{T}_{2}, 4 \mathrm{PM}\left({ }^{\circ} \mathrm{C}\right)$ & -0.1 & +0.1 & -0.5 & -0.3 & +0.1 & -0.3 \\
\hline $\mathrm{JJA} \mathrm{T}_{2}, 4$ AM $\left({ }^{\circ} \mathrm{C}\right)$ & -0.1 & +0.7 & +0.6 & -1.2 & -0.2 & -2.0 \\
\hline Ann $\mathrm{T}_{\mathrm{veg}}\left({ }^{\circ} \mathrm{C}\right)$ & 0 & +0.6 & -0.3 & -1.1 & -0.1 & -0.9 \\
\hline $\mathrm{JJA} \mathrm{T}_{\text {veg }}\left({ }^{\circ} \mathrm{C}\right)$ & +0.1 & +1.0 & -0.4 & -1.5 & -0.2 & -1.9 \\
\hline $\mathrm{JJA}_{\mathrm{veg}}, 4 \mathrm{PM}\left({ }^{\circ} \mathrm{C}\right)$ & 0 & +1.3 & -1.2 & -1.7 & -0.3 & -3.0 \\
\hline $\mathrm{JJA} \mathrm{T}_{\mathrm{veg}}, 4 \mathrm{AM}\left({ }^{\circ} \mathrm{C}\right)$ & +0.1 & +0.6 & +0.7 & -1.5 & -0.1 & -1.4 \\
\hline Ann SH $\left(\mathrm{W} \mathrm{m}^{-2}\right)$ & -2 & +2 & -12 & -11 & +3 & +8 \\
\hline JJA SH $\left(\mathrm{W} \mathrm{m}^{-2}\right)$ & -3 & +1 & -17 & -16 & +4 & +13 \\
\hline Ann LH $\left(\mathrm{W} \mathrm{m}^{-2}\right)$ & -1 & -6 & +8 & +3 & +1 & +7 \\
\hline JJA LH $\left(\mathrm{W} \mathrm{m}^{-2}\right)$ & -2 & -10 & +8 & +7 & +3 & +19 \\
\hline Ann 4 PM Alb. & +0.01 & 0 & +0.03 & +0.07 & -0.02 & -0.06 \\
\hline JJA 4 PM Alb. & +0.01 & +0.01 & +0.04 & +0.06 & -0.02 & -0.07 \\
\hline Ann SW $\left(\mathrm{W} \mathrm{m}^{-2}\right)$ & +1 & 0 & +2 & +2 & -1 & -5 \\
\hline
\end{tabular}




\begin{tabular}{lcccc|cc} 
JJA SW $\left(\mathrm{W} \mathrm{m}^{-2}\right)$ & +1 & 0 & +3 & +2 & -1 & -4 \\
Ann LW $\left(\mathrm{W} \mathrm{m}^{-2}\right)$ & 0 & +3 & -2 & -3 & 0 & -5 \\
JJA LW $\left(\mathrm{W} \mathrm{m}^{-2}\right)$ & +1 & +6 & -3 & -5 & -1 & -11 \\
Ann Pr $\left(\mathrm{mm} \mathrm{y}^{-1}\right)$ & -5 & -7 & +10 & -12 & +16 & +99
\end{tabular}

(Transition A is limited to $37-40^{\circ} \mathrm{N}$ and $120-122.5^{\circ} \mathrm{W}$; Transition B is within $40-42^{\circ} \mathrm{N}$ and $122-124^{\circ} \mathrm{W}$; Transition C is within $40.5-42^{\circ} \mathrm{N}$ and $120-121^{\circ} \mathrm{W}$; Transition $\mathrm{D}$ is limited to $40-42^{\circ} \mathrm{N}$ and $120-122^{\circ} \mathrm{W} . \mathrm{T}_{2}=2 \mathrm{~m}$ air temperature; $\mathrm{T}_{\text {veg }}=$ vegetation temperature; $\mathrm{SH}$ = sensible heat; $\mathrm{LH}=$ latent heat; Alb. = albedo; $\mathrm{SW}$ = downwelling shortwave at surface; $\mathrm{LW}=$ upwelling longwave at surface; $\mathrm{Pr}=$ total precipitation. Values are whole-day means unless otherwise specified.) 
Appendix A: Plant Functional Type Descriptions (PFT), Mapping to Vegetation Categories, and Parameters 
Table 4: California-specific plant functional types created in the Community Land Model (CLM) and example species.

\begin{tabular}{|c|c|c|}
\hline California PFT (code) & Major species & Other components \\
\hline $\begin{array}{l}\text { Temperate evergreen conifer } \\
\text { (TEGC) }\end{array}$ & $\begin{array}{c}\text { Douglas fir } \\
\text { Sugar pine } \\
\text { White fir } \\
\text { Incense cedar }\end{array}$ & $\begin{array}{c}\text { Red fir } \\
\text { Coulter pine } \\
\text { Grey or Foothill Pine }\end{array}$ \\
\hline $\begin{array}{l}\text { Fire-dependent evergreen conifer } \\
\text { (FIDC) }\end{array}$ & Ponderosa pine & \\
\hline $\begin{array}{l}\text { Fog-dependent evergreen conifer } \\
\text { (FODC) }\end{array}$ & $\begin{array}{c}\text { Coast redwood } \\
\text { Western Red Cedar }\end{array}$ & \\
\hline $\begin{array}{l}\text { Cold hardy evergreen conifer } \\
\text { (CHEGC) }\end{array}$ & $\begin{array}{c}\text { Lodgepole pine } \\
\text { Whitebark } \\
\text { Foxtail pine } \\
\text { Mountain hemlock }\end{array}$ & \\
\hline $\begin{array}{l}\text { Broadleaf evergreen tree } \\
\text { (BLEG) }\end{array}$ & $\begin{array}{c}\text { Canyon live oak } \\
\text { Interior live oak } \\
\text { Coast live oak }\end{array}$ & $\begin{array}{c}\text { California laurel } \\
\text { Tanbark oak } \\
\text { Madrone } \\
\text { Golden chinquapin }\end{array}$ \\
\hline $\begin{array}{l}\text { Cold deciduous broadleaf tree } \\
\text { (CDBT) }\end{array}$ & $\begin{array}{c}\text { Blue oak } \\
\text { Valley oak }\end{array}$ & $\begin{array}{c}\text { Black oak } \\
\text { California walnut } \\
\text { Western redbud }\end{array}$ \\
\hline $\begin{array}{l}\text { Drought deciduous broadleaf tree } \\
\text { (DDBT) }\end{array}$ & $\begin{array}{l}\text { California buckeye } \\
\text { Palo verde }\end{array}$ & $\begin{array}{c}\text { Blue palo verde } \\
\text { Smoketree }\end{array}$ \\
\hline $\begin{array}{c}\text { Drought-deciduous shrub } \\
\text { (DDS) }\end{array}$ & White bur sage & $\begin{array}{c}\text { Buckwheat } \\
\text { Brittle bush } \\
\text { California buckwheat } \\
\text { Black sage } \\
\text { White sage } \\
\text { Bitterbrush }\end{array}$ \\
\hline $\begin{array}{c}\text { Xeromorphic evergreen shrub } \\
\text { (XEGS) }\end{array}$ & $\begin{array}{l}\text { Creosote bush } \\
\text { Chamise }\end{array}$ & $\begin{array}{c}\text { Manzanita } \\
\text { Ceanothus } \\
\text { Big sagebrush }\end{array}$ \\
\hline
\end{tabular}




\begin{tabular}{|c|c|c|}
\hline Evergreen shrub & & Whiteleaf manzanita \\
\hline \multirow[t]{7}{*}{ (EGS) } & & Mountain misery \\
\hline & & Ceanothus spp. \\
\hline & & Mountain mahogany \\
\hline & & California flannelbush \\
\hline & & Toyon \\
\hline & & Hollyleaf cherry \\
\hline & & Woolly blue curls \\
\hline Cold deciduous shrub & Greasewood & Currant spp. \\
\hline (CDS) & Deerbrush & \\
\hline Perennial bunchgrass $\left(\mathrm{C}_{3}\right)$ & Needlegrass & Blue wheatgrass \\
\hline \multirow[t]{2}{*}{ (PGC3) } & Speargrass & Pine bluegrass \\
\hline & & Idaho fescue \\
\hline Annual grass $\left(\mathrm{C}_{4}\right)$ & Species not identified & \\
\hline \multicolumn{3}{|l|}{ (AGC4) } \\
\hline Succulents/cactus & Prickly pear & Compass barrel cactus \\
\hline \multirow[t]{4}{*}{ (SUC) } & Chaparral yucca & Ocotillo \\
\hline & & Silver cholla \\
\hline & & Diamond cholla \\
\hline & & Devil's cholla \\
\hline Herbaceous plants & & Many \\
\hline \multicolumn{3}{|l|}{ (HP) } \\
\hline Wetland monocots & & Common tule \\
\hline \multirow[t]{5}{*}{ (WM) } & & California bulrush \\
\hline & & Olney bulrush \\
\hline & & Tule \\
\hline & & Cattaill \\
\hline & & Soft flag \\
\hline
\end{tabular}




\section{Table 5: PFT combinations, including bare ground (BG) and water (W) for MC1 vegetation types that appear in California, and associated Küchler types.}

\begin{tabular}{|c|c|c|}
\hline California PFT fractions & MC1 vegetation type & Küchler vegetation types \\
\hline $\begin{array}{c}\text { 25\% PGC3; 23\% HP; } 0.03 \\
\text { CDS; 50\% BG }\end{array}$ & Tundra & Alpine meadows and barren \\
\hline $\begin{array}{c}\text { 70\% CHEGC; } 4 \% \text { HP; } 1 \% \\
\text { CDS; } 25 \% \text { BG }\end{array}$ & Boreal forest* & Lodgepole pine-subalpine forest \\
\hline $\begin{array}{c}\text { 53\% TEGC; } 18 \% \text { FODC; } \\
\text { 6\% CDS; } 23 \% \text { BG }\end{array}$ & Maritime temperate coniferous forest & $\begin{array}{l}\text { Cedar-hemlock-douglas fir forest } \\
\text { Mixed conifer forest } \\
\text { Redwood forest } \\
\text { Pine- cypress forest }\end{array}$ \\
\hline $\begin{array}{c}\text { 40\% TEGC; } 25 \% \text { FIDC; } \\
\text { 17\% EGS; } 18 \% \text { BG }\end{array}$ & Continental temperate coniferous forest & $\begin{array}{c}\text { Red fir forest } \\
\text { Ponderosa shrub forest } \\
\text { Great basin pine forest }\end{array}$ \\
\hline $\begin{array}{c}\text { 56\% BEGT; } 11 \% \text { CDBT; } \\
\text { 8\% TEGC; } 25 \% \text { BG }\end{array}$ & Warm temperate/subtropical mixed forest & California mixed evergreen forest \\
\hline $\begin{array}{c}\text { 37\% BEGT; } 21 \% \text { CDBT; } \\
\text { 17\% TEGC; } 26 \% \text { BG }\end{array}$ & Temperate mixed xeromorphic woodland & $\begin{array}{c}\text { California oak woods } \\
\text { California oak woods - Coastal } \\
\text { sagebrush mosaic }\end{array}$ \\
\hline $\begin{array}{c}\text { 36\% TEGC; } 15 \% \text { EGS; } 9 \% \\
\text { PGC3; 40\% BG }\end{array}$ & Temperate conifer xeromorphic woodland & Juniper-pinyon woodland \\
\hline $\begin{array}{c}\text { 32\% XEGS; 28\% PGC3; } \\
\text { 15\% TEGC; } 25 \% \text { BG }\end{array}$ & Temperate conifer savanna & Juniper steppe woodland \\
\hline $\begin{array}{c}\text { 31\% PGC3; 28\% AGC4; } \\
\text { 11\% HP; 30\% BG }\end{array}$ & $\mathrm{C}_{3}$ grassland $^{\dagger}$ & $\begin{array}{l}\text { Fescue-oatgrass } \\
\text { California steppe }\end{array}$ \\
\hline $\begin{array}{c}40 \% \text { AGC4; 10\% PGC3; } \\
\text { 10\% HP; 40\% BG }\end{array}$ & $\mathrm{C}_{4}$ grassland $^{\dagger}$ & \\
\hline 40\% XEGS; 16\% EGS; 9\% & Mediterranean shrubland & Chaparral \\
\hline
\end{tabular}




\begin{tabular}{|c|c|c|}
\hline DDS; 34\% BG & & $\begin{array}{l}\text { Montane chaparral } \\
\text { Coastal sagebrush }\end{array}$ \\
\hline \multirow{4}{*}{$\begin{array}{c}20 \% \text { XEGS; 8\% PGC3 } \\
\text { HP; 68\% BG }\end{array}$} & Temperate arid shrubland & Great basin sagebrush \\
\hline & & Saltbrush-greasewood \\
\hline & & Sagebrush steppe \\
\hline & & Desert: Vegetation largely absent \\
\hline \multirow{3}{*}{$\begin{array}{c}\text { 13\% XEGS; 6\% DDS; } \% \\
\text { SUC; } 78 \% \text { BG }\end{array}$} & Subtropical arid shrubland & Creosote bush \\
\hline & & Creosote bush - bur sage \\
\hline & & Palo verde - cactus shrub \\
\hline 50\% WM; 10\% BG; 40\% W & Wetland & Tule marshes \\
\hline
\end{tabular}

* Lenihan et al. 2008 do not have explicit Küchler vegetation assignments to their Boreal forest vegetation type; the Lodgepole pine-subalpine forest was used for the relevant type for California, and for assigning PFT fractions.

${ }^{\dagger}$ Lenihan et al. 2008 separately represent $\mathrm{C}_{3}$ and $\mathrm{C}_{4}$ grassland types, while in CLM3.5 “Mixed grassland” and “ $\mathrm{C}_{4}$ dominated grassland” both were represented as mixtures of $\mathrm{C}_{3}$ perennial and $\mathrm{C}_{4}$ grasses. $\mathrm{C}_{4}$ dominated grasslands were not present in the Küchler vegetation classes. 
Table 6: Parameter values used in CLM3 to represent new California specific PFTs. (Four CLM3.5 parameters were set identical to those of the most similar existing PFTs.) Not all PFTs were represented in the model domain.

\begin{tabular}{|c|c|c|c|c|c|c|c|c|c|c|c|c|c|c|c|c|c|c|c|c|}
\hline PFT & $\mathbf{A}$ & B & $\mathrm{C}$ & D & $\mathbf{E}$ & $\mathbf{F}$ & G & $\mathbf{H}$ & I & $\mathbf{J}$ & $\mathbf{K}$ & $\mathbf{L}$ & M & $\mathbf{N}$ & $\mathbf{O}$ & $\mathbf{P}$ & $\mathbf{Q}$ & $\mathbf{R}$ & $\mathbf{S}$ & $\mathbf{T}$ \\
\hline $\begin{array}{c}\text { temperate } \\
\text { evergreen } \\
\text { conifer }\end{array}$ & 17 & 8.5 & 0.01 & \begin{tabular}{|l|}
0.07 \\
\end{tabular} & 0.45 & 0.16 & 0.39 & 0.05 & 0.1 & 0.001 & \begin{tabular}{|l|}
0.001 \\
\end{tabular} & 0.04 & 0.14 & \begin{tabular}{|l|}
0.75 \\
\end{tabular} & 7 & 2 & 43 & 0.06 & 6 & $\mathrm{C}_{3}$ \\
\hline $\begin{array}{l}\text { fire-dependent } \\
\text { evergreen } \\
\text { conifer }\end{array}$ & 17 & 8.5 & 0.01 & \begin{tabular}{|l|}
0.07 \\
\end{tabular} & 0.35 & 0.16 & 0.39 & 0.05 & 0.1 & 0.001 & 0.001 & 0.04 & 0.13 & \begin{tabular}{|l|}
0.67 \\
\end{tabular} & 7 & 2 & 52 & 0.06 & 6 & $\mathrm{C}_{3}$ \\
\hline $\begin{array}{l}\text { fog-dependent } \\
\text { evergreen } \\
\text { conifer }\end{array}$ & 17 & 8.5 & 0.01 & \begin{tabular}{|l|}
0.07 \\
\end{tabular} & 0.35 & 0.16 & 0.39 & 0.05 & 0.1 & 0.001 & \begin{tabular}{|l|}
0.001 \\
\end{tabular} & 0.04 & 0.03 & \begin{tabular}{|l|}
0.84 \\
\end{tabular} & 7 & 2 & 36 & 0.06 & 6 & $\mathrm{C}_{3}$ \\
\hline $\begin{array}{c}\text { cold hardy } \\
\text { evergreen } \\
\text { conifer }\end{array}$ & 17 & 8.5 & 0.01 & \begin{tabular}{|l|}
0.07 \\
\end{tabular} & 0.35 & 0.16 & 0.39 & 0.05 & 0.1 & 0.001 & 0.001 & 0.04 & 0.05 & \begin{tabular}{|l|}
0.76 \\
\end{tabular} & 7 & 2 & 43 & \begin{tabular}{|l}
0.026 \\
\end{tabular} & 6 & $\mathrm{C}_{3}$ \\
\hline $\begin{array}{c}\text { broadleaf } \\
\text { evergreen tree }\end{array}$ & 35 & 1 & 0.1 & 0.1 & 0.45 & 0.16 & 0.39 & 0.05 & 0.25 & 0.001 & 0.001 & 0.04 & 0.075 & \begin{tabular}{|l|}
0.67 \\
\end{tabular} & 7 & 1 & 69 & 0.06 & 9 & $\mathrm{C}_{3}$ \\
\hline $\begin{array}{l}\text { cold deciduous } \\
\text { broadleaf tree }\end{array}$ & 20 & 11 & 0.25 & 0.1 & 0.45 & 0.16 & 0.39 & 0.05 & 0.25 & 0.001 & 0.001 & 0.04 & 0.13 & \begin{tabular}{|l|}
0.67 \\
\end{tabular} & 6 & 2 & 127 & 0.06 & 8 & $\mathrm{C}_{3}$ \\
\hline $\begin{array}{c}\text { drought } \\
\text { deciduous } \\
\text { broadleaf tree }\end{array}$ & 20 & 11 & 0.25 & 0.1 & 0.45 & 0.16 & 0.39 & 0.05 & 0.25 & \begin{tabular}{|l|}
0.001 \\
\end{tabular} & 0.001 & 0.04 & 0.13 & 0.67 & 6 & 2 & & 0.06 & 9 & $\mathrm{C}_{3}$ \\
\hline \begin{tabular}{c|} 
drought- \\
deciduous shrub
\end{tabular} & 1 & 0 & 0.25 & 0.2 & 0.6 & 0.16 & 0.39 & 0 & 0 & 0.001 & 0.001 & 0.04 & 0.12 & 0.68 & 7 & 1.5 & 182 & 0.06 & 9 & $\mathrm{C}_{3}$ \\
\hline $\begin{array}{c}\text { Xeromorphic } \\
\text { evergreen shrub }\end{array}$ & 2 & 0.5 & 0 & 0.1 & 0.5 & 0.16 & 0.39 & 0.01 & 0.01 & 0.001 & 0.001 & 0.04 & 0.12 & 0.68 & 7 & 1.5 & 100 & 0.02 & 9 & $\mathrm{C}_{3}$ \\
\hline evergreen shrub & 0.5 & 0.1 & 0.01 & 0.1 & 0.45 & 0.16 & 0.39 & 0.05 & 0.25 & 0.001 & 0.001 & 0.04 & 0.12 & \begin{tabular}{|l|}
0.68 \\
\end{tabular} & 7 & 1.5 & 17 & 0.06 & 9 & $\mathrm{C}_{3}$ \\
\hline deciduous shrub & 0.5 & 0.1 & 0.25 & 0.1 & 0.45 & 0.16 & 0.39 & 0.05 & 0.25 & 0.001 & 0.001 & 0.04 & 0.12 & \begin{tabular}{|l|}
0.68 \\
\end{tabular} & 7 & 1.5 & 17 & 0.06 & 9 & $\mathrm{C}_{3}$ \\
\hline $\begin{array}{c}\text { perennial } \\
\text { bunchgrass }\left(\mathrm{C}_{3}\right) \\
\end{array}$ & 0.5 & 0.01 & -0.3 & 0.11 & 0.58 & 0.36 & 0.58 & 0.07 & 0.25 & 0.22 & 0.38 & 0.04 & 0.15 & 0.57 & 11 & 2 & 75 & 0.06 & 9 & $\mathrm{C}_{3}$ \\
\hline \begin{tabular}{|l|} 
annual grass $\left(\mathrm{C}_{4}\right)$ \\
\end{tabular} & 0.5 & 0.01 & -0.3 & 0.11 & 0.58 & 0.36 & 0.58 & 0.07 & 0.25 & 0.22 & 0.38 & 0.04 & 0.12 & \begin{tabular}{|l|}
0.68 \\
\end{tabular} & 11 & 2 & 24 & 0.04 & 5 & $\mathrm{C}_{4}$ \\
\hline $\begin{array}{c}\text { succulents/cactus } \\
\text { (CAM) }\end{array}$ & 10 & 0 & -0.3 & 0.3 & 0.7 & 0.36 & 0.58 & 0 & 0 & 0.22 & 0.38 & 0.04 & 0.12 & 0.68 & 11 & 2 & 24 & 0.04 & 5 & $\mathrm{C}_{3}$ \\
\hline $\begin{array}{c}\text { herbaceous } \\
\text { plants }\end{array}$ & 0.5 & 0.01 & -0.3 & 0.11 & 0.58 & 0.36 & 0.58 & 0.07 & 0.25 & 0.22 & 0.38 & 0.04 & 0.12 & 0.68 & 6 & 3 & 50 & 0.06 & 9 & $\mathrm{C}_{3}$ \\
\hline $\begin{array}{c}\text { wetland } \\
\text { monocots }\end{array}$ & 1.5 & 0.01 & -0.3 & 0.11 & 0.58 & 0.36 & 0.58 & 0.07 & 0.25 & 0.22 & \begin{tabular}{|l}
0.38 \\
\end{tabular} & 0.04 & 0.12 & \begin{tabular}{|l|}
0.68 \\
\end{tabular} & 11 & 2 & 50 & 0.06 & 9 & $\mathrm{C}_{3}$ \\
\hline
\end{tabular}

A. Canopy top (m); B. Canopy bottom (m); C. Leaf orientation; D. Leaf visual reflectance; E. Leaf IR reflectance; F. Stem visual reflectance; G. Stem IR reflectance; H. Leaf visual transmittance; I. Leaf IR transmittance; J. Stem visual transmittance; K. Stem IR transmittance; L. Leaf characteristic dimension in direction of wind flow (m); M. Momentum roughness length ratio to canopy height; N. Displacement height ratio to canopy height; O. Root distribution parameter “ $\mathrm{r}_{\mathrm{a}}$ ”; P. Root distribution parameter " $\mathrm{r}_{\mathrm{b}}$ ”; Q. Max. rate of carboxylation at $25 \mathrm{C}$ (mmol CO $\mathrm{m}^{-2} \mathrm{~s}^{-1}$ ); R. Quantum efficiency (mmol $\mathrm{CO}_{2} \mathrm{mmol}^{-1}$ photons); S. Empirical parameter: slope of conductance-to-photosynthesis relationship; T. Photosynthetic pathway 
Table 7: Leaf Area Index Values for the New California PFTs, by Month

\begin{tabular}{|c|c|c|c|c|c|c|c|c|c|c|c|c|}
\hline PFT / Month & 1 & 2 & 3 & 4 & 5 & 6 & 7 & 8 & 9 & 10 & 11 & 12 \\
\hline temperate evergreen conifer & 1.00 & 1.52 & 1.53 & 1.48 & 2.13 & 3.15 & 3.59 & 3.52 & 3.28 & 2.63 & 2.32 & 1.77 \\
\hline fire-dependent evergreen conifer & 1.06 & 1.63 & 1.77 & 1.84 & 2.50 & 3.30 & 3.42 & 3.26 & 3.10 & 2.62 & 2.49 & 1.95 \\
\hline fog-dependent evergreen conifer & 4.04 & 4.22 & 4.70 & 4.69 & 5.21 & 5.35 & 5.45 & 5.29 & 4.94 & 4.70 & 4.23 & 3.81 \\
\hline cold hardy evergreen conifer & 0.27 & 0.28 & 0.26 & 0.29 & 0.44 & 0.83 & 1.17 & 1.19 & 1.11 & 0.77 & 0.57 & 0.46 \\
\hline broadleaf evergreen tree & 2.21 & 2.82 & 3.23 & 3.42 & 3.58 & 3.40 & 3.19 & 2.98 & 2.62 & 2.55 & 2.48 & 2.19 \\
\hline cold deciduous broadleaf tree & 1.77 & 2.33 & 2.77 & 2.93 & 2.91 & 2.78 & 2.64 & 2.45 & 2.19 & 2.07 & 2.11 & 1.80 \\
\hline drought deciduous broadleaf tree & 0.00 & 0.00 & 0.00 & 0.00 & 0.00 & 0.00 & 0.00 & 0.00 & 0.00 & 0.00 & 0.00 & 0.00 \\
\hline drought-deciduous shrub & 0.00 & 0.00 & 0.00 & 0.00 & 0.00 & 0.00 & 0.00 & 0.00 & 0.00 & 0.00 & 0.00 & 0.00 \\
\hline Xeromorphic evergreen shrub & 0.30 & 0.40 & 0.48 & 0.42 & 0.39 & 0.38 & 0.35 & 0.32 & 0.27 & 0.25 & 0.26 & 0.27 \\
\hline evergreen shrub & 1.41 & 1.63 & 2.21 & 2.40 & 2.48 & 2.36 & 2.17 & 1.89 & 1.57 & 1.48 & 1.42 & 1.32 \\
\hline deciduous shrub & 0.11 & 0.12 & 0.23 & 0.32 & 0.43 & 0.41 & 0.34 & 0.31 & 0.25 & 0.23 & 0.22 & 0.18 \\
\hline perennial bunchgrass (C) & 1.90 & 2.36 & 2.66 & 2.49 & 2.50 & 2.28 & 1.80 & 1.54 & 1.33 & 1.24 & 1.65 & 1.92 \\
\hline annual grass (C 4 ) & 1.59 & 2.09 & 2.42 & 2.10 & 1.46 & 0.94 & 0.79 & 0.71 & 0.60 & 0.69 & 1.34 & 1.38 \\
\hline succulents/cactus (CAM) & 0.32 & 0.37 & 0.52 & 0.52 & 0.46 & 0.40 & 0.35 & 0.32 & 0.28 & 0.26 & 0.29 & 0.30 \\
\hline herbaceous plants & 0.28 & 0.58 & 0.73 & 0.88 & 1.29 & 1.74 & 1.59 & 1.45 & 1.30 & 1.03 & 1.04 & 0.76 \\
\hline wetland monocots & 0.54 & 1.03 & 1.20 & 1.31 & 1.49 & 1.55 & 1.49 & 1.34 & 0.89 & 0.80 & 0.80 & 0.72 \\
\hline
\end{tabular}




\section{References}

Abatzoglou, J. T., K. T. Redmond, and L. M. Edwards, 2009: Classification of Regional Climate Variability in the State of California. Journal of Applied Meteorology and Climatology, 48, 1527-1541.

Abiodun, B. J., J. S. Pal, E. A. Afiesimama, W. J. Gutowski, and A. Adedoyin, 2008: Simulation of West African monsoon using RegCM3 Part II: impacts of deforestation and desertification. Theoretical and Applied Climatology, 93, 245-261.

Alo, C. A., and G. L. Wang, 2008: Hydrological impact of the potential future vegetation response to climate changes projected by 8 GCMs. Journal of Geophysical ResearchBiogeosciences, 113, 16.

Bala, G., K. Caldeira, M. Wickett, T. J. Phillips, D. B. Lobell, C. Delire, and A. Mirin, 2007: Combined climate and carbon-cycle effects of large-scale deforestation. Proceedings of the National Academy of Sciences of the United States of America, 104, 6550-6555.

Bell, J. L., and L. C. Sloan, 2006: CO2 sensitivity of extreme climate events in the Western United States. Earth Interactions, 10.

Betts, R., P. Falloon, K. Goldewijk, and N. Ramankutty, 2007: Biogeophysical effects of land use on climate: Model simulations of radiative forcing and large-scale temperature change. Agricultural and Forest Meteorology, 142, 216-233.

Bonan, G., 1998: The land surface climatology of the NCAR Land Surface Model coupled to the NCAR Community Climate Model. Journal of Climate, 11, 1307-1326.

- 1999: Frost followed the plow: Impacts of deforestation on the climate of the United States. Ecological Applications, 9, 1305-1315.

Bonan, G., S. Levis, L. Kergoat, and K. Oleson, 2002a: Landscapes as patches of plant functional types: An integrating concept for climate and ecosystem models. Global Biogeochemical Cycles, 16, -.

Bonan, G. B., 1997: Effects of land use on the climate of the United States. Climatic Change, 37, 449-486.

— 2008: Forests and climate change: Forcings, feedbacks, and the climate benefits of forests. Science, 320, 1444-1449.

Bonan, G. B., S. Levis, S. Sitch, M. Vertenstein, and K. W. Oleson, 2003: A dynamic global vegetation model for use with climate models: concepts and description of simulated vegetation dynamics. Global Change Biology, 9, 1543-1566.

Bonan, G. B., and Coauthors, 2002b: The land surface climatology of the community land model coupled to the NCAR community climate model. Journal of Climate, 15, 3123-3149.

Bounoua, L., R. DeFries, G. J. Collatz, P. Sellers, and H. Khan, 2002: Effects of land cover conversion on surface climate. Climatic Change, 52, 29-64. 
Brown, S., A. Dushku, T. Pearson, D. Shoch, J. Winsten, S. Sweet, and J. Kadyszewski, 2004: Carbon Supply from Changes in Management of Forest, Range, and Agricultural Lands of California. PIER Energy-Related Environmental Research, Winrock International, for the California Energy Commission, 500-504-068F.

Caldwell, P., H. N. S. Chin, D. C. Bader, and G. Bala, 2009: Evaluation of a WRF dynamical downscaling simulation over California. Climatic Change, 95, 499-521.

Cayan, D. R., E. P. Maurer, M. D. Dettinger, M. Tyree, and K. Hayhoe, 2008: Climate change scenarios for the California region. Climatic Change, 87, S21-S42.

Chen, F., and J. Dudhia, 2001: Coupling an advanced land surface-hydrology model with the Penn State-NCAR MM5 modeling system. Part II: Preliminary model validation. Monthly Weather Review, 129, 587-604.

Chen, S., and W. Sun, 2002: A one-dimensional time dependent cloud model. Journal of the Meteorological Society of Japan, 80, 99-118.

Chin, H.-N. S., P. M. Caldwell, and D. C. Bader, 2009: Exploration of California Wintertime Model Wet Bias: Sensitivity of WRF Physics AND Measurement Uncertainty. WRF Users Workshop, NCAR, Boulder, CO.

Chou, M.-D., and M. J. Suarez, 1994: An efficient thermal infrared radiation parameterization for use in general circulation models. NASA Tech. Memo. 104606, 85 pp.

Collins, W. D., and Coauthors, 2006: The Community Climate System Model version 3 (CCSM3). Journal of Climate, 19, 2122-2143.

Cooley, H. S., W. J. Riley, M. S. Torn, and Y. He, 2005: Impact of agricultural practice on regional climate in a coupled land surface mesoscale model. Journal of Geophysical ResearchAtmospheres, 110.

Dai, Y. J., R. E. Dickinson, and Y. P. Wang, 2004: A two-big-leaf model for canopy temperature, photosynthesis, and stomatal conductance. Journal of Climate, 17, 2281-2299.

Daly, C., and Coauthors, 2008: Physiographically sensitive mapping of climatological temperature and precipitation across the conterminous United States. International Journal of Climatology, 28, 2031-2064.

Davis, F. W., and Coauthors, 1998: The California Gap Analysis Project: Final Report. University of California, Santa Barbara. http://www.biogeog.ucsb.edu/projects/gap/gap_rep.html

DeFries, R. S., L. Bounoua, and G. J. Collatz, 2002: Human modification of the landscape and surface climate in the next fifty years. Global Change Biol., 8, 438-458.

Delworth, T., and Coauthors, 2006: GFDL's CM2 global coupled climate models. Part I: Formulation and simulation characteristics. Journal of Climate, 19, 643-674.

Denning, A. S., M. Nicholls, L. Prihodko, I. Baker, P. L. Vidale, K. Davis, and P. Bakwin, 2003: Simulated variations in atmospheric CO2 over a Wisconsin forest using a coupled ecosystematmosphere model. Global Change Biology, 9, 1241-1250.

Dickinson, R. E., and Coauthors, 2006: The Community Land Model and its climate statistics as a component of the Community Climate System Model. Journal of Climate, 19, 2302-2324. 
Diffenbaugh, N. S., 2005: Atmosphere-land cover feedbacks alter the response of surface temperature to CO2 forcing in the western United States. Climate Dynamics, 24, 237-251.

— 2009: Influence of modern land cover on the climate of the United States. Climate Dynamics.

Durieux, L., L. A. T. Machado, and H. Laurent, 2003: The impact of deforestation on cloud cover over the Amazon arc of deforestation. Remote Sensing of Environment, 86, 132-140.

Feddema, J., K. Oleson, G. Bonan, L. Mearns, W. Washington, G. Meehl, and D. Nychka, 2005a: A comparison of a GCM response to historical anthropogenic land cover change and model sensitivity to uncertainty in present-day land cover representations. Climate Dynamics, 25, 581-609.

Feddema, J. J., K. W. Oleson, G. B. Bonan, L. O. Mearns, L. E. Buja, G. A. Meehl, and W. M. Washington, 2005b: The importance of land-cover change in simulating future climates. Science, 310, 1674-1678.

Feng, X., A. Sahoo, K. Arsenault, P. Houser, Y. Luo, and T. J. Troy, 2008: The Impact of Snow Model Complexity at Three CLPX Sites. Journal of Hydrometeorology, 9, 1464-1481.

Foley, J. A., M. H. Costa, C. Delire, N. Ramankutty, and P. K. Snyder, 2003: Green surprise? How terrestrial ecosystems could affect earth's climate. Frontiers in Ecology and Environment, 1, 38-44.

Friedlingstein, P., and Coauthors, 2006: Climate-carbon cycle feedback analysis: Results from the (CMIP)-M-4 model intercomparison. Journal of Climate, 19, 3337-3353.

Gallus, W. A., and J. F. Bresch, 2006: Comparison of impacts of WRF dynamic core, physics package, and initial conditions on warm season rainfall forecasts. Monthly Weather Review, 134, 2632-2641.

Ge, J. J., J. G. Qi, B. M. Lofgren, N. Moore, N. Torbick, and J. M. Olson, 2007: Impacts of land use/cover classification accuracy on regional climate simulations. Journal of Geophysical Research-Atmospheres, 112.

Gibbard, S., K. Caldeira, G. Bala, T. Phillips, and M. Wickett, 2005: Climate effects of global land cover change. Geophysical Research Letters, 32, -.

Giorgi, F., and C. Shields, 1999: Tests of precipitation parameterizations available in latest version of NCAR regional climate model (RegCM) over continental United States. Journal of Geophysical Research-Atmospheres, 104, 6353-6375.

Grubisic, V., R. K. Vellore, and A. W. Huggins, 2005: Quantitative precipitation forecasting of wintertime storms in the Sierra Nevada: Sensitivity to the microphysical parameterization and horizontal resolution. Monthly Weather Review, 133, 2834-2859.

Hayhoe, K., and Coauthors, 2004: Emissions pathways, climate change, and impacts on California. Proceedings of the National Academy of Sciences of the United States of America, 101, 12422-12427.

Henderson-Sellers, A., P. Irannejad, K. McGuffie, and A. J. Pitman, 2003: Predicting landsurface climates - better skill or moving targets? Geophysical Research Letters, 30. 
Hong, S., Y. Noh, and J. Dudhia, 2006: A new vertical diffusion package with an explicit treatment of entrainment processes. Monthly Weather Review, 134, 2318-2341.

Hughes, M. K., and H. F. Diaz, 2008: Climate variability and change in the drylands of Western North America. Global and Planetary Change, 64, 111-118.

Jackson, R., and Coauthors, 2005: Trading water for carbon with biological sequestration. Science, 310, 1944-1947.

—, 2008: Protecting climate with forests. Environmental Research Letters, 3, 044006.

Jin, J. M., and N. L. Miller, 2007: Analysis of the impact of snow on daily weather variability in mountainous regions using MM5. Journal of Hydrometeorology, 8, 245-258.

Johns, T., and Coauthors, 2003: Anthropogenic climate change for 1860 to 2100 simulated with the HadCM3 model under updated emissions scenarios. Climate Dynamics, 20, 583-612.

Juang, J., G. Katul, M. Siqueira, P. Stoy, and K. Novick, 2007: Separating the effects of albedo from eco-physiological changes on surface temperature along a successional chronosequence in the southeastern United States. Geophysical Research Letters, 34, -.

Kain, J., 2004: The Kain-Fritsch convective parameterization: An update. Journal of Applied Meteorology, 43, 170-181.

Kanamitsu, M., W. Ebisuzaki, J. Woollen, S. Yang, J. Hnilo, M. Fiorino, and G. Potter, 2002: NCEP-DOE AMIP-II reanalysis (R-2). Bulletin of the American Meteorological Society, 83, 1631-1643.

Kueppers, L. M., M. A. Snyder, and L. C. Sloan, 2007: Irrigation cooling effect: Regional climate forcing by land-use change. Geophysical Research Letters, 34.

Kueppers, L. M., and Coauthors, 2008: Seasonal temperature responses to land-use change in the western United States. Global and Planetary Change, 60, 250-264.

Küchler, A. W., and American Geographical Society of New York., 1975: Potential natural vegetation of the conterminous United States. American Geographical Society.

Lamptey, B. L., E. J. Barron, and D. Pollard, 2005: Impacts of agriculture and urbanization on the climate of the Northeastern United States. Global and Planetary Change, 49, 203-221.

Lawrence, D., P. Thornton, K. Oleson, and G. Bonan, 2007: The partitioning of evapotranspiration into transpiration, soil evaporation, and canopy evaporation in a GCM: Impacts on land-atmosphere interaction. Journal of Hydrometeorology, 8, 862-880.

Lenihan, J. M., R. J. Drapek, D. Bachelet, and R. P. Neilson, 2003: Climate change effects on vegetation distribution, carbon stocks and fire regimes in California. Ecological Applications, 13, 1667-1681.

Lenihan, J. M., D. Bachelet, R. P. Neilson, and R. Drapek, 2008: Response of vegetation distribution, ecosystem productivity, and fire to climate change scenarios for California. Climatic Change, 87, S215-S230.

Leung, L., Y. Qian, X. Bian, W. Washington, J. Han, and J. Roads, 2004: Mid-century ensemble regional climate change scenarios for the western United States. Climatic Change, 62, 75-113. 
Lobell, D. B., C. Bonfils, and J. M. Faures, 2008a: The role of irrigation expansion in past and future temperature trends. Earth Interactions, 12, 1-11.

Lobell, D. B., C. J. Bonfils, L. M. Kueppers, and M. A. Snyder, 2008b: Irrigation cooling effect on temperature and heat index extremes. Geophysical Research Letters, 35.

McPherson, R. A., 2007: A review of vegetation-atmosphere interactions and their influences on mesoscale phenomena. Progress in Physical Geography, 31, 261-285.

Michelson, S. A., and J. W. Bao, 2008: Sensitivity of Low-Level Winds Simulated by the WRF Model in California's Central Valley to Uncertainties in the Large-Scale Forcing and Soil Initialization. Journal of Applied Meteorology and Climatology, 47, 3131-3149.

Miller, N., and Coauthors, 2009: An Analysis of Simulated California Climate Using Multiple Dynamical and Statistical Techniques. PIER Program Area: Climate Change, California Energy Commission, CEC-500-2009-017-D.

Mlawer, E., S. Taubman, P. Brown, M. Iacono, and S. Clough, 1997: Radiative transfer for inhomogeneous atmospheres: RRTM, a validated correlated-k model for the longwave. Journal of Geophysical Research-Atmospheres, 102, 16663-16682.

Nakicenovic, N., and R. Swart, Eds., 2000: Special Report on Emissions Scenarios. Cambridge University Press.

Narisma, G. T., and A. J. Pitman, 2006: Exploring the sensitivity of the Australian climate to regional land-cover-change scenarios under increasing CO2 concentrations and warmer. Earth Interactions, $\mathbf{1 0 .}$

Notaro, M., S. Vavrus, and Z. Y. Liu, 2007: Global vegetation and climate change due to future increases in $\mathrm{CO} 2$ as projected by a fully coupled model with dynamic vegetation. Journal of Climate, 20, 70-90.

Oleson, K. W., G. B. Bonan, C. Schaaf, F. Gao, Y. F. Jin, and A. Strahler, 2003: Assessment of global climate model land surface albedo using MODIS data. Geophysical Research Letters, 30, 4.

Oleson, K. W., and Coauthors, 2008: Improvements to the Community Land Model and their impact on the hydrological cycle. Journal of Geophysical Research-Biogeosciences, 113.

— 2004: Technical Description of the Community Land Model (CLM). National Center for Atmospheric Research, NCAR/TN 461+STR.

Pielke, R. A., and Coauthors, 2007: An overview of regional land-use and land-cover impacts on rainfall. Tellus Series B-Chemical and Physical Meteorology, 59, 587-601.

Pitman, A. J., 2003: The evolution of, and revolution in, land surface schemes designed for climate models. International Journal of Climatology, 23, 479-510.

Pongratz, J., L. Bounoua, R. S. DeFries, D. C. Morton, L. O. Anderson, W. Mauser, and C. A. Klink, 2006: The impact of land cover change on surface energy and water balance in Mato Grosso, Brazil. Earth Interactions, 10. 
Qian, T. T., A. G. Dai, K. E. Trenberth, and K. W. Oleson, 2006: Simulation of global land surface conditions from 1948 to 2004. Part I: Forcing data and evaluations. Journal of Hydrometeorology, 7, 953-975.

Ramankutty, N., C. Delire, and P. Snyder, 2006: Feedbacks between agriculture and climate: An illustration of the potential unintended consequences of human land use activities. Global and Planetary Change, 54, 79-93.

Roy, S. B., and R. Avissar, 2002: Impact of land use/land cover change on regional hydrometeorology in Amazonia. Journal of Geophysical Research-Atmospheres, 107.

Roy, S. B., G. C. Hurtt, C. P. Weaver, and S. W. Pacala, 2003: Impact of historical land cover change on the July climate of the United States. Journal of Geophysical Research-Atmospheres, 108.

Sacks, W. J., B. I. Cook, N. Buenning, S. Levis, and J. H. Helkowski, 2009: Effects of global irrigation on the near-surface climate. Climate Dynamics, 33, 159-175.

Sellers, P., 1985: Canopy Reflectance, Photosynthesis, and Transpiration. International Journal of Remote Sensing, 6, 1335-1372.

Sitch, S., and Coauthors, 2003: Evaluation of ecosystem dynamics, plant geography and terrestrial carbon cycling in the LPJ dynamic global vegetation model. Global Change Biology, 9, 161-185.

Skamarock, B., 2009: Monotonic and Positive Definite Transport Options in the ARW V3.1 Release. WRF Users Workshop, NCAR, Boulder, CO.

Skamarock, W. C., and J. B. Klemp, 2008: A time-split nonhydrostatic atmospheric model for weather research and forecasting applications. Journal of Computational Physics, 227, 34653485.

Skamarock, W. C., and Coauthors, 2008: A Description of the Advanced Research WRF Version 3. Mesoscale and Microscale Meteorology Division, National Center for Atmospheric Research, NCAR/TN-475+STR.

Snyder, M. A., and L. C. Sloan, 2005: Transient future climate over the western United States using a regional climate model. Earth Interactions, 9.

Snyder, M. A., L. C. Sloan, N. S. Diffenbaugh, and J. L. Bell, 2003: Future climate change and upwelling in the California Current. Geophys. Res. Lett., 30, DOI:10.1029/2003GL017647.

Snyder, M. A., J. L. Bell, L. C. Sloan, P. B. Duffy, and B. Govindasamy, 2002: Climate responses to a doubling of atmospheric carbon dioxide for a climatically vulnerable region. Geophysical Research Letters, 29, 4.

Snyder, P. K., C. Delire, and J. A. Foley, 2004a: Evaluating the influence of different vegetation biomes on the global climate. Climate Dynamics, 23, 279-302.

Snyder, P. K., J. A. Foley, M. H. Hitchman, and C. Delire, 2004b: Analyzing the effects of complete tropical forest removal on the regional climate using a detailed three-dimensional energy budget: An application to Africa. Journal of Geophysical Research-Atmospheres, 109, 22. 
Steiner, A. L., J. S. Pal, F. Giorgi, R. E. Dickinson, and W. L. Chameides, 2005: The coupling of the Common Land Model (CLM0) to a regional climate model (RegCM). Theoretical and Applied Climatology, 82, 225-243.

Steiner, A. L., and Coauthors, 2009: Land surface coupling in regional climate simulations of the West African monsoon. Climate Dynamics, 33, 869-892.

Strack, J. E., R. A. Pielke, L. T. Steyaert, and R. G. Knox, 2008: Sensitivity of June near-surface temperatures and precipitation in the eastern United States to historical land cover changes since European settlement. Water Resources Research, 44.

Swann, A. L., I. Y. Fung, S. Levis, G. B. Bonan, and S. C. Doney, 2010: Changes in Arctic vegetation amplify high-latitude warming through the greenhouse effect. Proceedings of the National Academy of Sciences of the United States of America, 107, 1295-1300.

Thonicke, K., S. Venevsky, S. Sitch, and W. Cramer, 2001: The role of fire disturbance for global vegetation dynamics: coupling fire into a Dynamic Global Vegetation Model. Global Ecology and Biogeography, 10, 661-677.

Torn, M., and J. Harte, 2006: Missing feedbacks, asymmetric uncertainties, and the underestimation of future warming. Geophysical Research Letters, 33, -.

Washington, W., and Coauthors, 2000: Parallel climate model (PCM) control and transient simulations. Climate Dynamics, 16, 755-774.

Weare, B. C., and H. Du, 2008: Modelling regional climate changes: influences of recent global warming and irrigation in California. International Journal of Climatology, 28, 1201-1212.

Weiss, J. L., C. L. Castro, and J. T. Overpeck, 2009: Distinguishing Pronounced Droughts in the Southwestern United States: Seasonality and Effects of Warmer Temperatures. Journal of Climate, 22, 5918-5932.

Winter, J. M., J. S. Pal, and E. A. B. Eltahir, 2009: Coupling of Integrated Biosphere Simulator to Regional Climate Model Version 3. Journal of Climate, 22, 2743-2757.

Xu, X. K., F. Zhang, and J. K. Levy, 2007: The influence of land surface changes on regional climate in northwest China. Advances in Atmospheric Sciences, 24, 527-537.

Yang, Z. L., and R. E. Dickinson, 1996: Description of the biosphere-atmosphere transfer scheme (BATS) for the soil moisture workshop and evaluation of its performance. Elsevier Science Bv, 117-134.

Zhao, M., A. J. Pitman, and T. Chase, 2001: The impact of land cover change on the atmospheric circulation. Climate Dynamics, 17, 467-477. 


\section{DISCLAIMER}

This document was prepared as an account of work sponsored by the United States Government. While this document is believed to contain correct information, neither the United States Government nor any agency thereof, nor the Regents of the University of California, nor any of their employees, makes any warranty, express or implied, or assumes any legal responsibility for the accuracy, completeness, or usefulness of any information, apparatus, product, or process disclosed, or represents that its use would not infringe privately owned rights. Reference herein to any specific commercial product, process, or service by its trade name, trademark, manufacturer, or otherwise, does not necessarily constitute or imply its endorsement, recommendation, or favoring by the United States Government or any agency thereof, or the Regents of the University of California. The views and opinions of authors expressed herein do not necessarily state or reflect those of the United States Government or any agency thereof or the Regents of the University of California. 